University of Rhode Island

DigitalCommons@URI

Open Access Master's Theses

1993

\title{
The Effects of Sample Size, Reliability, Number of Indicators Per Factor and Estimation Method on Fit Indices
}

Lin Ding

University of Rhode Island

Follow this and additional works at: https://digitalcommons.uri.edu/theses

\section{Recommended Citation}

Ding, Lin, "The Effects of Sample Size, Reliability, Number of Indicators Per Factor and Estimation Method on Fit Indices" (1993). Open Access Master's Theses. Paper 1570.

https://digitalcommons.uri.edu/theses/1570

This Thesis is brought to you for free and open access by DigitalCommons@URI. It has been accepted for inclusion in Open Access Master's Theses by an authorized administrator of DigitalCommons@URI. For more information, please contact digitalcommons-group@uri.edu. 
THE EFFECTS OF SAMPLE SIZE, RELIABILITY, NUMBER OF INDICATORS PER FACTOR AND ESTIMATION METHOD ON FIT INDICES

BY

LIN DING

A THESIS SUBMITTED IN PARTIAL FULFILLMENT OF THE REQUIREMENTS FOR THE DEGREE OF MASTERS OF ARTS

IN

PSYCHOLOGY

$3269 \% \div \%$

UNIVERSITY OF RHODE ISLAND

1993 


\begin{abstract}
A simulation study was conducted to evaluate the effects of sample size (N), reliability/loading (L), Number of indicators per factor $(\mathrm{p} / \mathrm{m})$ and estimation method $(\mathrm{E})$ on seven fit indices, including three frequently used fit indices: Chi-square $\left(\chi^{2}\right)$, Normed Fit Index (NFI) and Nonnormed of Fit Index (NNFI), and four recently proposed fit indices: Noncentrality $d$ index, Centrality $m$ index, Relative Noncentrality Index (RNI) and Comparative Fit Index (CFI). The performance of these indices were examined over four levels of $N(50,100,200$ and 500$)$, three levels of $L(0.50,0.70$ and 0.90$)$, five levels of $\mathrm{p} / \mathrm{m}(2,3,4,5$ and 6), and two levels of estimation method (GLS and ML). The results of this study imdicated that: 1) All seven indices showed downward bias when sample sizes were small. However, RNI and CFI were relatively less affected by sample size than other indices. 2) Reliability/Loading did not have strong effects on these fit indices (except NFI) in general. 3) All seven fit indices showed downward bias when $\mathrm{p} / \mathrm{m}$ ratio increased. This effect is much more severe on $\chi^{2}, \mathrm{NFI}, d$ and $m$ then on NNFI, RNI and CFI. 4) All seven fit indices were found to be estimation method specific. The interaction effects of these influence factors were strong. The effect of $\mathrm{p} / \mathrm{m}$ ratio on fit indices is related to the parsimony problem. The correctness of parsimony justification of these indices was also investigated and discussed.
\end{abstract}




\section{Acknowledgement}

I would like to thank Dr. Jim Prochaska and Dr. Cynthia Willey Lessne, for kindly agreeing to be on my Master's committee.

I would also like to thank Dr. Joe Rossi for his helpful comments on my thesis proposal.

I owe a great deal of thanks to Dr. Joe Fava. He is always willing to answer my questions and give suggestions on my research. He taught me most of the techniques I needed to do this simulation study.

My special thanks to Dr. Lisa Harlow. Her advice and suggestions were invaluable in the process of developing this research idea and throughout the course of this study. Without her inspiration and encouragement, this thesis could not have been done.

As my major professor, Dr. Wayne Velicer provided extensive stimulation and support. His insightful guidance on this project had made this thesis a valuable and meaningful study. Wayne's high standards have encouraged me to always excel in my work. I can not thank him enough.

Finally, I would like to thank my husband, Qi Zhou, for his encouragement, understanding and support. I would like to dedicate this thesis to my parents and my dear grandmother, they live in my hometown, WeiFang, China. 
Table of contents

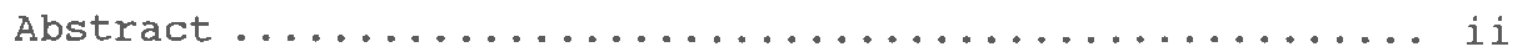

Acknowledgement ........................... $\ldots \ldots$

Table of contents ......................... iv

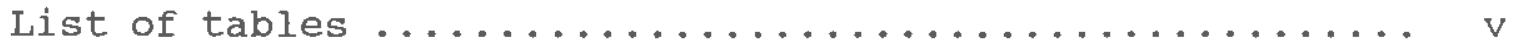

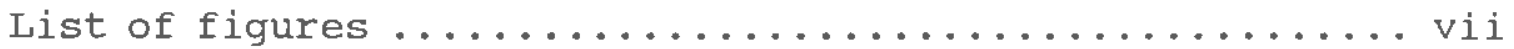

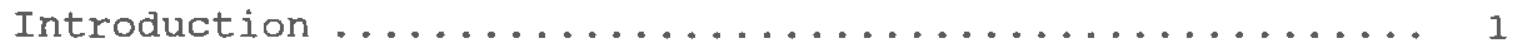

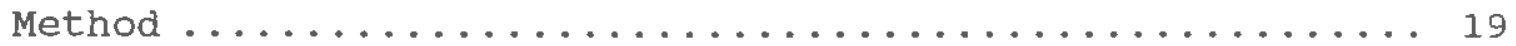

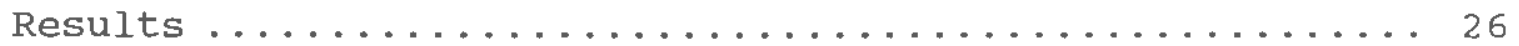

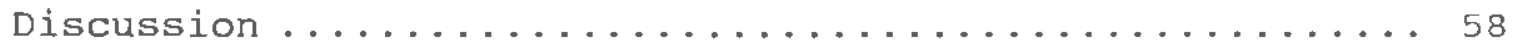

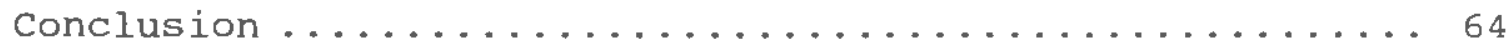

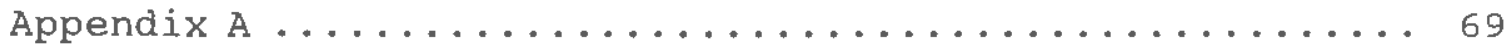

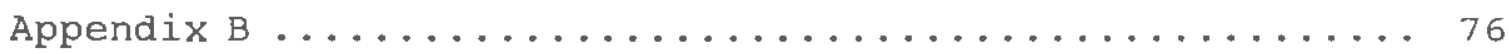

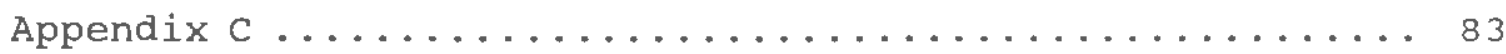

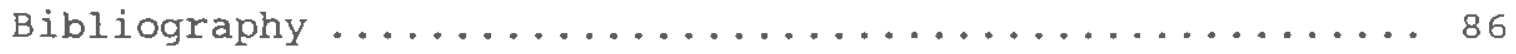




\section{List of Tables}

Table

Page

1. Summary of 14 indices to be evaluated. ......... 11

2. Example of population variance covariance matrix $(\mathrm{p} / \mathrm{m}=2$, Loading=0.5) $\ldots \ldots \ldots \ldots 24$

3. Frequency distribution of non-convergent cases among 100 replicates across all conditions ........................... 27

4. Frequency distribution of boundary cases among 100 replicates across all conditions ....... 28

5. Percentage of significant Chi-square value $(\alpha=.05)$ across all conditions ................. 30

6. Percentage of significant parsimoniously adjusted Chi-square value $(\alpha=.05)$ across

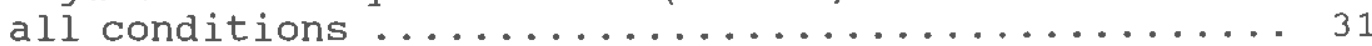

7. Means and standard Deviations for the Normed Fit Index ........................ 33

8. Means and standard Deviations for the Nonnormed Fit Index ...................... 38

9. Means and standard Deviations for the Noncentrality $d$ index .................... 43

10. Means and standard Deviations for the

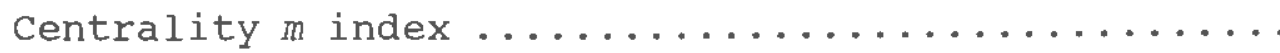

11. Means and standard Deviations for the

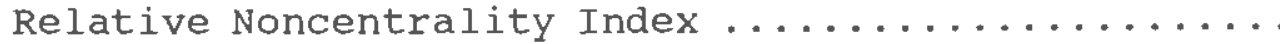

12. Means and Standard Deviations for the Comparative Fit Index .................... 55

13. Summary of results ........................ 65

A-1. MANOVA summary table for Normed Fit Index ....... 70

A-2. MANOVA summary table for Nonnormed Fit Index .... 71 A-3. MANOVA summary table for Noncentrality d Index ... 72 
A-4. MANOVA summary table for Centrality m Index ..... 73

A-5. MANOVA summary table for Relative Noncentrality Index ................... 74

A-6. MANOVA summary table for Comparative Fit Index ... 75

B-1. Means and Standard Deviations for the Parsimonious Normed Fit Index ............. 77

B-2. Means and Standard Deviations for the Parsimonious Nonnormed Fit Index ........... 78

B-3. Means and Standard Deviations for the Parsimonious Noncentrality d Index .......... 79

B-4. Means and Standard Deviations for the Parsimonious Noncentrality m Index ........... 80

B-5. Means and Standard Deviations for the Parsimonious Relative Noncentrality Index ....... 81

B-6. Means and standard Deviations for the

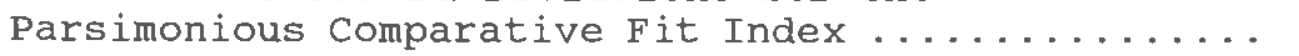




\section{List of Figures}

\section{Figure}

Page

1. Estimated model with $\mathrm{p} / \mathrm{m}=2$ and Loading $=.50 \ldots 20$

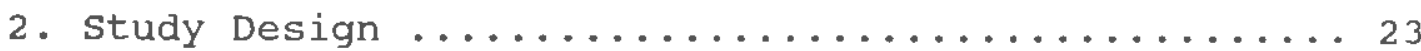

3. Mean values of Normed Fit Index across all conditions under GLS estimation ........... 34

4. Mean values of Normed Fit Index across all conditions under ML estimation ........... 35

5. Mean values of Nonnormed Fit Index across all conditions under GLS estimation ........... 39

6. Mean values of Nonnormed Fit Index across all conditions under $\mathrm{ML}$ estimation ........... 40

7. Mean values of Noncentrality $d$ Index across all conditions under GLS estimation ........... 44

8. Mean values of Noncentrality $d$ Index across all conditions under ML estimation ........... 45

9. Mean values of Centrality $m$ Index across all conditions under GLS estimation .......... 48

10. Mean values of Centrality in Index across all conditions under ML estimation ............ 49

11. Mean values of Relative Noncentrality Index across all conditions under GLS estimation ........... 52

12. Mean values of Relative Noncentrality Index across all conditions under ML estimation ........... 53

13. Mean values of Comparative Fit Index across all conditions under GLS estimation .......... 56

14. Mean values of Comparative Fit Index across all conditions under ML estimation ........... 57

C-1. Mean values of Parsimonious Normed Fit Index across all conditions under GLS estimation ...... 84

C-2. Mean values of Parsimonious Normed Fit Index across all conditions under ML estimation ....... 85 


\section{INTRODUCTION}

Structural modeling attempts to explain the relationships among a set of observed variables in terms of a generally smaller number of latent unobserved variables. The relationships among the observed variables are characterized by the covariances among those variables (Long, 1983). In its general form, a structural model has two components: a ineasurement model which usually consists of one or more latent factors linking the observed variables to the unobserved variables, and a structural equation model depicting the relationship(s) among the latent variables.

The measurement model can be expressed as

$$
y=\Lambda_{y} \eta+\epsilon
$$

where $y$ is a $(p \times 1)$ vector of observed variables, $\eta$ is a $(m \times 1)$ vector of common factors (exogenous and endogenous latent variables), and $\epsilon(p \times 1)$ is a vector of unique factors or errors in measurement. $\Lambda_{y}$ is a $(p \times m)$ matrix of the loadings of the $y$ 's on the $\eta$ 's.

The structural equation model can be expressed as

$$
\eta=\mathbf{B} \eta+\zeta
$$

where $\mathbf{B}$ is a $(\mathrm{m} \times \mathrm{m})$ matrix of coefficients relating the latent variables to one another, and $\zeta$ is a $(\mathrm{m} \times 1)$ vector of errors in equations or prediction error.

Most applications of structural modeling involves following four consecutive steps:

(1) Model specification. This refers to formulating the initial model prior to estimation by depicting the hypothesized relationships among the variables. This model 
is formulated on the basis of one's theory or past research in the area (Bollen \& Long, 1993).

(2) Identification. This refers to determining whether it is possible to find unique values for the parameters of the specified model. If a model can not be identified, the estimation results are meaningless (Bollen \& Long, 1993).

(3) Estimation. The general objective in estimating the structural model is to find estimates of the parameters that reproduce the sample matrix of variances and covariances of the observed variables as closely as possible. There are several estimation methods available. Selection of estimation techniques is often determined by the distributional properties of the variables being analyzed (Long, 1983; Bollen \& Long, 1993).

(4) Testing Fit. After the estimates are obtained, the researcher can test whether the model is consistent with the data. If so, the process can stop after this fourth step. More typically, the fit of the model could be improved through respecification. Diagnostic indicators are available to guide respecification. Once respecified, step 2 through 4 may be repeated.

Although all steps in applying structural modeling are important researching issues, testing fit has received the most attention. This is because assessing fit is an important issue both theoretically and empirically, and because despite years of work in this area, it remains one of the most controversial topics in structural modeling research. Many fit indices have been proposed, none of which has been generally accepted as the 'best index' by the majority of researchers (Bollen \& Long, 1993) 
The aim of this project is to empirically evaluate several alternative fit indices, some of which have not been studied as much, under a wide range of conditions using simulated data.

\section{The Development of Fit Indices}

In the early literature on structural modeling, the likelihood ratio chi-square statistic was widely used to evaluate fit. The rationale for this fit assessment is that: if the model was specified correctly and if the distributional assumptions for the data were satisfied, then analysts could use the test statistic which has an asymptotic $\chi^{2}$ distribution to test the null hypothesis that the specified model leads to an exact reproduction of the population covariance matrix of the observed variables (Bollen \& Long, 1993). As its rationale indicates, $\chi^{2}$ is a badness-of-fit measure -- it gets larger as the fit worsens. This test has been criticized by numerous researchers (e.g., Gerbing \& Anderson, 1993). First, it is a badness-of-fit test, i.e., it attempts to prove the null hypothesis. The value of the statistic can go to infinity, which indicates a poor degree of fit. Second, sample size has a strong effect on its value ( e.g., Bentler \& Bonett, 1980; Marsh,Balla \& McDonald, 1988). Increasing sample size leads to increasing statistical power. Therefore, when sample size becomes increasingly large, even a correctly specified model could be rejected. This tendency can be proven by it's formula $\chi^{2}=(\mathrm{N}-1) \mathrm{FF}$, where $\mathrm{FF}$ is the fitting function obtained by a particular estimator and $\mathrm{N}$ is the sample size. FF is independent of sample size, so, two equally well fitting models can have the same FF value. However, the model with the larger sample will have a larger $\chi^{2}$. The bigger the 
$\chi^{2}$ value, the more likely it is statistically significant, and the more likely it is to be rejected. Third, the test is very sensitive to violations of the distribution assumptions (Harlow, 1985). With highly kurtotic data, the $\chi^{2}$ will tend to be inflated, thus leading to a higher probability of incorrectly rejecting a correct model. Fourth, the performance of this test statistic in simulation studies, i.e. under ideal conditions, has shown that it can be very inaccurate (Zwick \& Velicer, 1982, 1986; Velicer \& Jackson, 1990).

Since the realization of these major problems with $\chi^{2}$ as a fit index, researchers have developed alternate fit indices (e.g., Bentler \& Bonett, 1980; Hoetler, 1983; James, Mulaik \& Brett, 1982; Jorekog \& Sorbom, 1981). In fact, a large number of indices have been developed. Selecting a good fit index is now a problem, because there are so many and none has yet proven to be superior to all others.

Gerbing and Anderson (1993) proposed three properties which the ideal fit index should have: (1) Indicate degree of fit along a continuum bounded by the values 0 and 1 , where 0 reflects a complete lack of fit and 1 reflects perfect fit; (2) be independent of sample size (higher or lower values would not be obtained simply because the sample size is large or small); and (3) have known distributional characteristics to assist interpretation and allow the construction of a confidence interval.

Although a few indices have demonstrated one or more of these properties, no one index has convincingly been shown to satisfy all of these conditions acceptably. Further, not all researchers would even agree with all these criteria. However, results from studies which evaluate fit indices can: (1) guide the interpretation of the fit indices; (2) provide a basis for selecting a fit indices; and (3) provide an overview of the 
performance of the index under different conditions.

\section{Alternative Fit Indices}

Different fit indices have been proposed based on different theoretical justifications. Most indices attempt to assess the degree to which the model accounts for the sample covariances. Marsh, Balla and McDonald (1988) classified fit indices into three types: (1) Stand-alone Indices, (2) Type I Incremental Fit Indices, and (3) Type II Incremental Fit Indices.

Stand-alone Indices. These indices are based on the results compared to just the target model. The target model is the a priori model posited by the researcher to fit the data. The $\chi^{2}$ test and $\chi^{2} / \mathrm{df}$ ratio are of this type of index.

Incremental Fit Indices. Bentler \& Bonett(1980) proposed that model fit can be evaluated by the degree to which the model accounts for the sample covariances relative to a more restricted model. Typically this involves a series of nested models, i.e, a series of succeedingly more complex models, each including all of the parameters of the simpler model. The most basic model is usually a null model in which all the observed variables are assumed to be uncorrelated, and only " $\mathrm{p}$ " variables are estimated. This approach yields incremental fit indices. The two alternative forms of the incremental indices are:

$$
\begin{aligned}
& \text { Type I indices }=|t-n| / \operatorname{Max}(t, n) \\
& \text { Type II indices }=|t-n| /|e-n|
\end{aligned}
$$

where $t$ is the value of a stand-alone index for the target model, $n$ is the value for the 
null model, and $e$ is the expected value of the stand-along index if the target model is true.

A Type I Fit Index involves only empirically derived values for the null and target models. The Normed Fit Index (NFI) (Bentler \& Bonett, 1980) based on $\chi^{2}$ values for the null and target models, belongs to this type. James et al (1982) have found that both Stand-alone and Type I Incremental Fit Indices can be improved by simply freeing more parameters regardless of the appropriateness of the model. Therefore, James et al. (1982) proposed a new class of indices that adjusts for the additional degrees of freedom (df) included in parsimonious models. A Parsimonious Fit Index invokes a penalty function for using additional parameters by multiplying a Stand-alone or a Type I Incremental Index by the ratio of the $d f$ s for the target over the null models.

In addition to empirically derived values for the target and null models, a Type II Incremental Index requires the expected value for a true model (e.g. Nonnormed Fit Index (NNFI)). For example, when indices of this type are based on $\chi^{2}$, the expected value for a true model $\chi^{2}$ is the $d f$. This type of index, by definition, takes $d f$ into account, which is supposed to avoid the problem of not adjusting for the use of additional parameters. Therefore, theoretically, parsimony indices for this type would be unnecessary.

Besides the parsimony issue, the dependence of the fit index on sample size is another problem. The obtained value of most proposed indices have been showed to be noticeably biased downward for relatively small sample sizes (e.g. Marsh, Balla and McDonald, 1988). McDonald (1989), Steiger (1990), and Bentler (1990) proposed a 
class of new indices based on the use of the noncentrality parameter from the noncentral $\chi^{2}$ distribution. These new incremental indices are supposed to be sample size independent. While these new indices are promising, an empirical evaluation of their performance is needed.

A total of seven indices, including three Stand-Alone Indices, a Type I Incremental Fit Index, and three Type II Incremental Fit Indices were chosen for inclusion in this study. Some of these indices have been frequently reported in the application literature, but there is only limited evaluation information. The parsimony version of all these indices is also evaluated. Even though Type II Incremental Fit Indices have taken df into account as part of their formulation, deriving parsimonious indices based on them can be used as a comparison to see if these indices really do not need this adjustment.

The seven indices that are assessed in this study are described more fully below.

\section{Definitions of Fit Indices}

\section{Chi-Square Index.}

Let $\chi_{\mathrm{n}}{ }^{2}$ be the Chi-square value for the null model with degrees of freedom $d f_{n}$; let $\chi_{\mathrm{l}}^{2}$ be the Chi-square value for the target model with degrees of freedom $d f$, and:

$$
d f_{n}=p \times(p-1) / 2
$$

[6] $d f_{t}=[p \times(p+1) / 2]-t$

where $p$ is the number of observed variables and $t$ is the number of free parameters in the model. The Chi-Square index to be evaluated is simply $\chi_{\mathrm{L}}^{2}$. 


\section{Normed Fit Index (NFI).}

Based on empirically derived Chi-square values for the target $\left(\chi_{1}{ }^{2}\right)$ and null $\left(\chi_{n}{ }^{2}\right)$ models described above, Bentler and Bonett (1980) proposed their Type I Incremental Fit Index as:

$[7]$

$$
\text { NFI }=\left(\chi_{n}^{2}-\chi_{t}^{2}\right) / \chi_{n}^{2}
$$

This index assesses fit by comparing the target model with a more restricted null model in which all observed variables are assumed to be uncorrelated. The NFI can range from zero to one, with values closer to one preferred. This would correspond to having a smaller $\chi_{\mathrm{l}}{ }^{2}$ value compared to the $\chi_{\mathrm{n}}{ }^{2}$ value, also indicating better model fit.

\section{Nonnormed Fit Index (NNFI).}

Based on the Tucker-Lewis (1973) index (TLI), which was developed in factor analysis, Bentler and Bonett (1980) proposed their Type II Incremental Fit Index , the Nonnormed Fit Index (NNFI), which involves the $\chi^{2} / \mathrm{df}$ ratio rather than just the simple $\chi^{2}$ value. The index can be expressed as

$$
\mathrm{NNFI}=\left(\chi_{n}{ }^{2} / d f_{n}-\chi_{i}{ }^{2} / d f_{1}\right) /\left(\chi_{n}{ }^{2} / d f_{n}-1\right)
$$

Unlike NFI, NNFI can exceed the 0 and 1 range.

NFI and NNFI have been used in an absolute sense, where 1 indicates a perfect fit and 0 indicates a complete lack of fit (as bad as the null model). An index value of 0.9 or above has been conventionally regarded as indicating good to excellent fit for both fit indices. 


\section{Noncentrality $d$ Index.}

The noncentrality $d$ is an index proposed by McDonald (1989) and others. Let $\delta$ be the noncentrality parameter from the noncentral $\chi^{2}$ distribution. Then, $d$ is a sample estimate of $\delta$, where small values of $d$ indicate good fit, and

$$
d=\chi_{1}^{2} /(N-1)-d f / N
$$

where $\mathrm{N}$ is sample size. The $d$ index is not bounded by the 0 to $\mathrm{l}$ range of the NFI and NNFI, and can take on any value.

\section{Centrality Index $m$}

For ease of interpretation, McDonald (1989) defines the following index of centrality,

$$
m=\exp (-1 / 2 d)
$$

This index is bounded by 0 and 1 , where 1 indicates perfect fit. However, sampling error can make $m$ exceed 1 . Both $d$ and $m$ are stand-alone indices.

\section{Relative Noncentrality Index (RNI).}

A Type II Incremental Fit index based on $d$ alone, the relative noncentrality index (RNI), was defined by McDonald and Marsh (1990, p.250) as

$$
\mathrm{RNI}=1-d_{t} / d_{n},
$$

where $d_{t}$ is the $d$ value for the target model, and $d_{n}$ is the $d$ value for null model. Although a value of 0 indicates a complete lack of fit, and I indicates a perfect fit, RNI, like NNFI, is not necessarily bounded by 0 and $I$. 


\section{Comparative Fit Index (CFI).}

For interpretational ease, Bentler's (1990, p.241) Comparative Fit Index is preferable. This index is defined as

$$
\text { CFI }=1-d_{t}^{*} / d_{n}^{*},
$$

where $d_{t}^{*}=\max \left(d_{t}, 0\right)$ and $d_{n}^{*}=\max \left(d_{n}, d_{t}, 0\right)$. By definition, $d_{t}^{*}$ and $d_{\mathrm{n}}{ }^{*}$ are nonnegative. Because $d_{\mathrm{n}}^{*}>d_{i}^{*}$, CFI is normed, bounded between 0 and 1, with 1 indicating a perfect fit. When the value of RNI is between 0 and $1, \mathrm{RNI}=\mathrm{CFI}$.

The last four indices were only recently proposed and have not been studied extensively.

For each of the seven indices, the corresponding parsimony indices (PI) can be derived as

$$
\mathrm{PI}_{\mathrm{t}}=\left(d f_{t} / d f_{n}\right) I_{t}
$$

where $I_{l}$ is any of the above fit indices, e.g.,

$$
\text { PNFI }=\left(\mathrm{df}_{\mathrm{i}} / \mathrm{df}_{\mathrm{n}}\right) \text { NFI. }
$$

Therefore a total of 14 indices will be evaluated in this study. They are summarized in Table 1. 
Table 1

Summary of 14 Indices to be Evaluated

Index

Regular

Parsimonious

Chi-Square

$x^{2}$

$\mathrm{P} \times \chi^{2}$

Normed Fit Index

NFI

PXNFI

Nonnormed Fit Index

NNFI

P NNFI

Noncentrality Index

$d$

$\mathrm{P} \times d$

Centrality Index

$m$

$\mathrm{P} \times m$

Relative Noncentrality Index

RNI

P $\times$ RNI

Comparative Fit Index

CFI

P $\times$ CFI

Note. $\mathrm{P}=\left(\mathrm{df_{ \textrm {t } }} / \mathrm{df_{ \textrm {n } }}\right) ; \mathrm{df}=$ degrees of freedom in a target model; $d f_{n}=$ degrees of freedom in a null model. 


\section{Fit index and estimation}

Let $\mathbf{S}$ be the sample covariance matrix and let $\Sigma$ be the population covariance matrix. For a general structural model, $\Sigma$ can be decomposed into four possible functions of the parameter matrices:

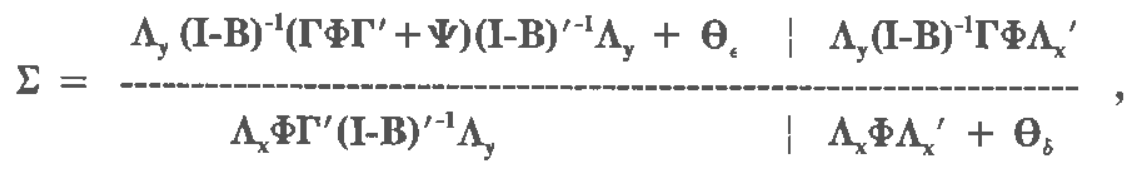

where $\Lambda_{x}$ is a loading matrix of exogenous observed variables on exogenous latent variables; $\boldsymbol{\Lambda}_{\mathrm{y}}$ is a loading matrix of endogenous observed variables on endogenous variables; $\mathbf{B}$ is a matrix of coefficients relating the endogenous latent variables to one another; and $\Gamma$ is a matrix of coefficients relating the exogenous latent variables to the endogenous variables. $\Phi$ is a matrix of correlations among latent exogenous variables. $\Psi$ is a covariance or correlation matrix of the errors. $\boldsymbol{\theta}_{\delta}$ is a matrix of unique factors for observed exogenous variables. $\boldsymbol{\theta}_{\mathbf{\varepsilon}}$ is a matrix of unique factors for observed endogenous variables.

An estimate of $\Sigma$ is $\Sigma^{*}$, where $\Sigma^{*}$ is defined by the estimation of the corresponding parameters in the covariance matrix. The problem of estimation is to measure how close $\Sigma^{*}$ is to $\mathbf{S}$, and to find the values of parameters that produce the $\Sigma^{*}$ that is as close as possible to $\mathbf{S}$. A function that measures how close a given $\Sigma^{*}$ is to the sample covariance matrix $\mathbf{S}$ is called a fitting function, $\mathbf{F}\left(\mathbf{S}, \Sigma^{*}\right)$.

Different estimation methods are available. Some make assumptions about the distributional properties of data (such as generalized least squares (GLS) and Maximum Likelihood (ML)), and some do not (such as unweighted least squares (ULS)). When the 
data has a multivariate normal distribution, both GLS and ML have desirable asymptotic properties (Browne, 1974), which gives GLS and ML the advantage of having test statistics associated with them, while ULS does not.

Given the same data set, summaries of fit based on different estimation procedures should yield approximately the same results. However, a limited number of studies which investigated the effects of estimation method on fit indices (e.g., Tanaka, 1993; La Du \& Tanaka, 1989) have shown that many fit indices vary as a function of estimation method. Therefore, fit indices must be evaluated under different estimation methods. Although GLS is widely available, ML has been predominantly used in both applications of structural modeling and simulation studies of fit indices. Since relatively little is known about the behavior of fit indices with GLS, both GLS and ML will be used in this study.

The GLS fitting function is

$$
\mathrm{F}_{\mathrm{GLS}}=\operatorname{tr}\left[\left(\mathbf{S}-\Sigma^{*}\right) \mathbf{S}^{-1}\right]^{2}
$$

The ML fitting function is

$$
\mathrm{F}_{\mathrm{ML}}=\operatorname{tr}\left(\Sigma^{*-1} \mathbf{S}\right)+\left[\log \left|\Sigma^{*}\right|-\log |\mathbf{S}|\right]-p,
$$

where $\Sigma^{*}$ is the estimated population covariance matrix, $\mathbf{S}$ is the sample covariance matrix, and $p$ is the number of observed variables, including both independent and dependent variables.

In this study, normal data will be used. Results from both estimators will be compared, and the effects of estimation methods and their interaction effects with other factors such as sample size, loading size, and $\mathrm{p} / \mathrm{m}$ ratio will be evaluated. 


\section{Potential Factors Influencing the Fit Indices}

Sample size, loading size, $\mathrm{p} / \mathrm{m}$ ratio (number of indicators $(\mathrm{p})$ per factor $(\mathrm{m})$ )) and estimation method have been recognized as factors that may affect the fit indices.

Sample Size. When the multivariate normality assumption is met, the effect of sample size on the goodness of fit indices has been studied by a number of researchers (e.g. Anderson \& Gerbing, 1984; Bearden, Sharma \& Teel, 1982; Boomsma, 1982, 1985; Marsh et al., 1988; Mulaik et al., 1989). These studies have come to similar conclusions: 100 is the minimum recommended sample size for a model. Studies investigating the relation of sample size to component pattern or factor pattern recovery (e.g., Velicer, Peacock \& Jackson, 1982; Velicer \& Fava, 1993; Guadagnoli \& Velicer, 1988) have found that a minimum sample size of 150 is usually sufficient to obtain accurate estimation.

Loading / Reliability. The effect of the size of the loading/reliability in structural modeling has only been studied by a few researchers (e.g., Boomsma 1982; Anderson \& Gerbing, 1984). However, a great deal of research has been done in the field of Factor/Component Analysis ( Velicer, 1974; Guadagnoli \& Velicer, 1988; Velicer \& Fava, 1987, 1993; Fava \& Velicer,1992a, 1992b, 1993). The FA/PCA studies conducted by Velicer and his colleagues have found that the size of a loading has a very strong effects on factor pattern recovery (Velicer \& Fava,1987) and the stability of a factor pattern (Guadagnoli \& Velicer, 1988), with higher values preferred. Studies by 
Boomsma (1982) and Anderson and Gerbing (1984), using a confirmatory factor model, did not find that loading/reliability had as strong an effect as sample size on the goodness of fit indices. Since there have not been many studies studying this in a structural modeling framework, it is of interest to determine the extent to which the findings from FA/PCA studies generalize to structural modeling, which is more complex than FA/PCA.

Ratio of Indicators to Factors $(\mathrm{p} / \mathrm{m})$. Findings evaluating the effect of $\mathrm{p} / \mathrm{m}$ ratio (number of indicators per factor) are even more complex. The general conclusions are well established in the FA/PCA literature: The more indicators per factor, the better pattern recovery (Velicer \& Fava, 1987, 1993). Also, the more stable the factor pattern, the less affected it will be by under-or over-extraction of factor/components (Fava \& Velicer, 1992b, 1993). Findings from a very limited number of studies in the confirmatory factor analysis area are more complicated. Anderson and Gerbing (1984) used three levels of number indicators per factor $(2,3,4)$ for their confirmatory factor model. They found that with more indicators per factor, the proportion of convergent and proper solutions increased. This replicates the factor analysis results of Velicer and Fava (1987, 1993). However, the value of the Goodness of Fit indices decreased (i.e. indicating a worse model fit with more indicators). The reason for this, as noted by Gerbing and Anderson (1993), is probably related to the issue of parsimony. However, such a result is troubling because more indicators should always be a positive situation. Clearly, more research about the effect of number of indicators per factor is needed. 
Estimation Method. The effect of estimation method on fit indices has been largely overlooked in the literature of structural modeling (Tanaka, 1993). Most of the findings are based on Maximum Likelihood estimation exclusively. Although GLS has the same asymptotic property as ML when the normality assumption is met (Browne, 1984), a study conducted by La Du and Tanaka (1989) found that even supposedly estimationmethod-free fit indices (such as NFI) were affected by choice of estimator. However, this study only considered sample size. Interaction effects involving estimation method with loading size and $\mathrm{p} / \mathrm{m}$ ratio were not considered. Most of the comparisons between GLS and ML have focused on the problem of nonnormality (e.g. Huba \& Harlow, 1983; Harlow, 1985; Muthen \& Kaplan,1985; Brown 1990). GLS and ML have been found to be robust and result in similar solutions for normal to moderately skewed data (Muthen \& Kaplan, 1985; Huba \& Harlow, 1983; Harlow, 1985). Unfortunately, all these conclusions are based on sample sizes of 400 or more. It seems that GLS has been assumed to be perform identically to ML when the data is normally distributed. However, only limited empirical evidence exists to support this assumption.

Interaction Effects. Sample size, loading size, and $\mathrm{p} / \mathrm{m}$ ratio may interact with each other. Fit indices may perform worse under the combinations of poor conditions (e.g. small sample size combined with low loadings). On the other hand, when sample size is sufficiently large (e.g., 400 or more) or the loadings are high (e.g., 0.8 or higher), the other factors may have little effect on indices. Interaction effects involving estimation method with these other factors have not been sufficiently evaluated. 


\section{Goals of This Study}

This project will expand previous studies of fit indices in the following ways:

(1) The most important feature of this study, compared to previous studies, is that a general form of a structural model will be used rather than a simple confirmatory factor analysis (CFA) model (as most previous simulation studies used). ln a structural model, the population covariance matrix is based on $\Lambda_{x}, \Lambda_{y}, \boldsymbol{\Phi}, \boldsymbol{\Psi}, \mathbf{B}, \boldsymbol{\Gamma}, \boldsymbol{\theta}_{\delta}$, and $\boldsymbol{\theta}_{\epsilon}$. This involves more, and different kinds of, parameters than in a confirmatory factor model. In a CFA model, the population covariance matrix is reduced to $\Lambda_{\mathbf{x}} \Phi \Lambda_{y}+\boldsymbol{\theta}_{\delta}$. The addition of a structural equation model will introduce regression coefficients and prediction errors into the reproduction of the covariance matrix. This makes a structural model a more complex model than a CFA model. Most structural modeling applications are more interested in the structural relationships among the latent variables, rather than just the relationships between the latent and manifest variables. Therefore, in practice, a general structural model may be more relevant than a confirmatory factor model. Conclusions based on a structural model will have more generalizability.

(2) This study will simultaneously evaluate a large number of fit indices, whereas most other studies have chosen only a smaller set of similar types of fit indices to evaluate. LISREL's (Joreskog \& Sorbom, 1981) fit indices such as GFI, AGFI and RMR have received extensive evaluation. For other indices there is almost no empirical evaluations available. This study tries to evaluate all three types of fit indices, choosing representive set of fit indices for each type. Among them, $\chi^{2}$ has been studied by many researchers. It is included here as a comparison to other fit indices. NFI and NNFI been 
evaluated empirically. NFI has been found to substantially underestimate fit under conditions of small sample size. NNFI has been found to perform better with small sample sizes on average, but has demonstrated large sample variation (Mulaik et al, 1989; Marsh et al., 1988). NFI has been found to be estimation specific (La Du \& Tanaka, 1989). However, none of these indices has been evaluated for effects of $\mathrm{p} / \mathrm{m}$ ratio, and NNFI has not been evaluated for estimation method effect. The recently proposed indices, $d, m, \mathrm{RNI}$ and CFI, are supposed to be sample size independent. However, they have not been evaluated under a wide range of conditions. The results of this study will provide useful information regarding the performance of these fit indices. (3). The impact of parsimonious corrections on different fit indices will be evaluated. The effect of $\mathrm{p} / \mathrm{m}$ ratio should be related to the problem of parsimony. The $d f_{t} / d f_{n}$ ratio for each $\mathrm{p} / \mathrm{m}$ ratio $(2,3,4,5,6)$ in this study are $0.46,0.69,0.79,0.83$, and 0.86 , respectively. As we can see, the larger the $\mathrm{p} / \mathrm{m}$ ratio, the more parsimonious the model. Since James et al. (1982) introduced parsimonious indices into the literature, little research has been done to address such issues as: (a) What is the optimal value (upper bound) of a parsimony index under perfect conditions? Because the $d f_{t} / d f_{n}$ ratio will always be less than 1 (unless the true model actually is the null model), even when the model has a perfect fit value for some index, e.g. when $N F I=1$, the value for its corresponding PNFI will generally be less than 1 . This feature of the parsimony index makes it very difficult to interpret. In this study, models will be correctly specified and the obtained value of the parsimony index under these conditions should be the optimal value. This will provide valuable information for researchers who use these indices. (b) 
Is the adjustment provided by a parsimony index accurate? The purpose of a parsimonious fit index is to adjust stand-alone and type I indices. However, little research has been done to determine if this adjustment is correct, i.e. neither an under-or overadjustment. This study will address this issue.

(4) All these indices will be evaluated for both GLS and ML solutions. Issues regarding to the effect of estimation methods and its interaction effect with other factors such as sample size, loading, and $\mathrm{p} / \mathrm{m}$ ratio on fit indices will be addressed. This will expand the La Du and Tanaka (1989) study.

\section{METHOD}

\section{Hypothesized Models}

A three-construct model (the first two serve as uncorrelated independent factors and the third as a dependent factor) was hypothesized as the population structure underlying the simulations. Five levels of the number of indicators and three levels of indicator reliability were combined for a total of fifteen initial population or true variance-covariance matrices to be generated. The population or true values for the variances of the two independent constructs were set at 1.00 . The regression coefficients and prediction error for the dependent construct were set at 0.50 for all the models.

An example of this model with 2 indicators per factor is illustrated in Figure 1. 

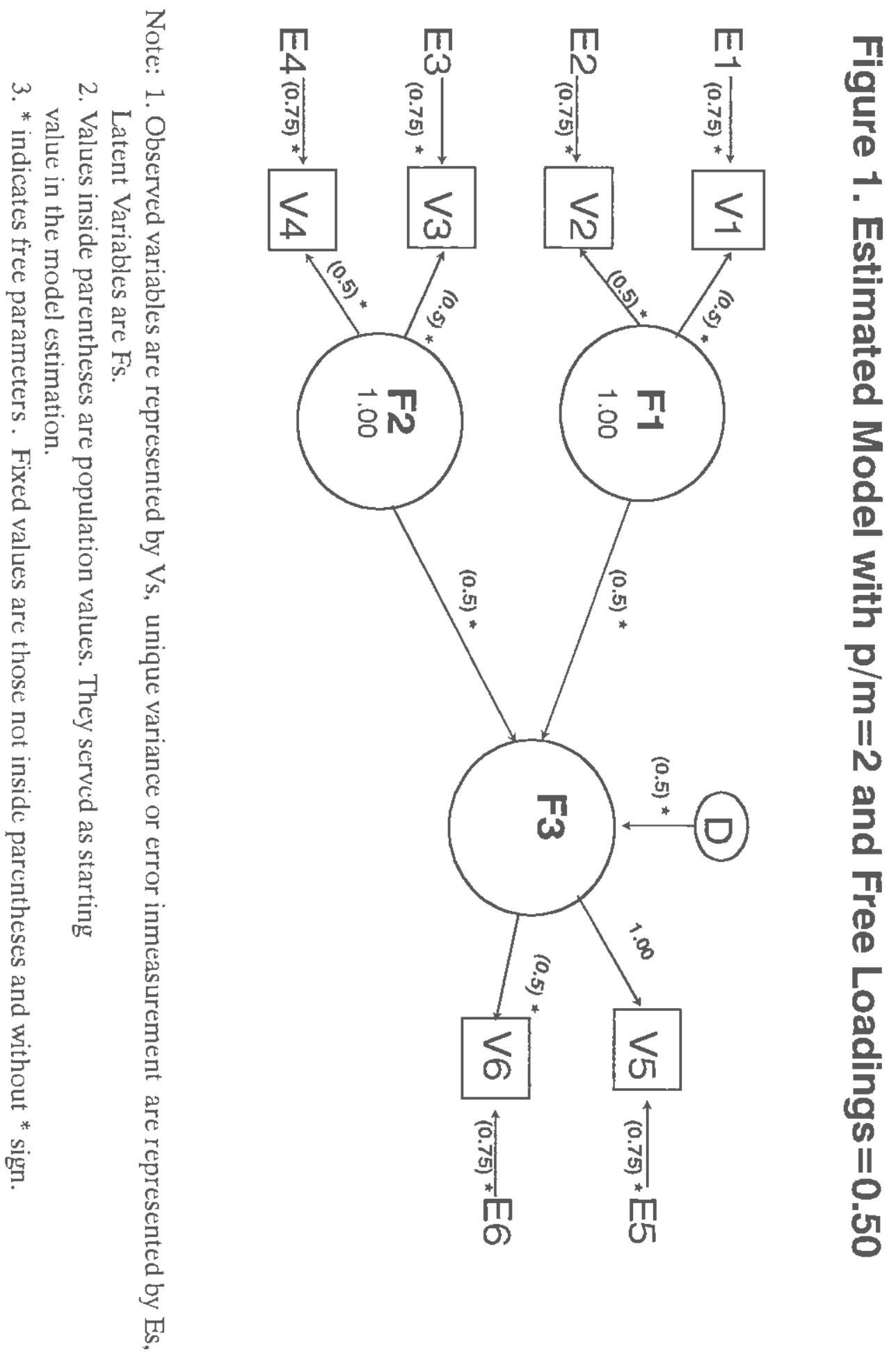


\section{Study Design}

The design is a $4 \times 3 \times 5 \times 2$ ( 4 levels of sample size, 3 levels of loadings, 5 levels of the number of indicators per factor, 2 levels of estimation method) factorial design with repeated measures over the last factor (estimation methods).

For most multivariate studies, a sample size of 80 is considered to be fairly low and may produce unreliable results. Sample sizes over 200 are thought to produce stable results (Boomsma, 1982; Velicer et al. 1982; Guadagnoli \& Velicer, 1988). However, in structural modeling applications, researchers have used sample sizes as small as 50 . In order to cover a wide range of sample sizes found in structural modeling applications, four levels of sample sizes were chosen: $50,100,200$, and 500 . This range has been suggested by the literature (Anderson \& Gerbing, 1984) to reflect a sample size ranging from very poor (50), fair (100), good (200) to excellent (500).

Low to high loadings (the square root of indicator reliabilities) are represented by uniform loadings of $0.50,0.70$, and 0.90 . In a measurement model, a loading of 0.40 is commonly used as cut off point for selecting a item. When loadings exceed 0.80 , indicators are considered to be very solid (Velicer et al.,1982). In this study, we choose 0.50 as the lower bound instead of 0.40 based on reliability considerations. For a loading of 0.5 , only 25 percent of this indicator's variance is explained by the factor it belongs to. This is already a very low value.

The lowest bound of $\mathrm{p} / \mathrm{m}$ ratio for a latent factor is 2 indicators per factor. Previous research in factor analysis (e.g. Guadagnoli \& Velicer, 1988; Velicer \& Fava, $1987,1993)$ suggests that the variable to factor ratio is crucial to factor stability and 
pattern recovery. The ratio $\mathrm{p} / \mathrm{m}=3$ is the lowest acceptable bound, based on the Anderson and Rubin (1956) identification conditions. In the structural modeling applications, $\mathrm{p} / \mathrm{m}=6$ or more is rare. Most applications fall within the range of 2-5. In order to evaluate the effect of $\mathrm{p} / \mathrm{m}$ ratio thoroughly, we included 2 as our lower bound, and 6 as our upper bound. This range covers almost all possible structural modeling applications.

The design of this study is illustrated in Figure 2.

\section{Sample generation}

The coinbination of three levels of loadings and five levels of $\mathrm{p} / \mathrm{m}$ ratio results in a total of fifteen population variance-covariance matrices. An example of a population variance-covariance is given in Table 2. EQS is a structural modeling program developed by Bentler (1989). The PC version (Bentler \& Wu, 1990) has a built-in simulation procedure. This procedure was used to generate sample covariance matrices.

With four sample sizes for each initial population model, a total of 60 sets of sainple variance-covariance matrices were generated with 100 replications in each set. Multivariate normal distributions were assumed. All models were perfectly specified.

Each sample was estimated using EQS. Both GLS and ML solutions were produced. $\chi_{n}^{2}, \chi_{1}^{2}$, NFI and NNFI are part of the regular output of EQS. In addition, the $d, m, \mathrm{RNI}$, and CFI indices and all $\mathrm{PI}_{t} \mathrm{~s}$ were calculated. 
Figure 2. Study Design

\begin{tabular}{|c|c|c|c|c|}
\hline \multirow[b]{2}{*}{ Sample Size } & \multirow[b]{2}{*}{ Loading Size } & \multirow[b]{2}{*}{$\mathrm{p} / \mathrm{m}$ ratio } & \multicolumn{2}{|c|}{$\begin{array}{c}\text { Estimation } \\
\text { Method }\end{array}$} \\
\hline & & & GLS & ML \\
\hline \multirow{3}{*}{$\mathrm{N}=50$} & .50 & $\begin{array}{l}2 \\
3 \\
4 \\
5 \\
6\end{array}$ & & \\
\hline & .70 & $\begin{array}{l}2 \\
3 \\
4 \\
5 \\
6\end{array}$ & & \\
\hline & .90 & $\begin{array}{l}2 \\
3 \\
4 \\
5 \\
6\end{array}$ & & \\
\hline \multirow{3}{*}{$\mathrm{N}=100$} & .50 & $\begin{array}{l}2 \\
3 \\
4 \\
5 \\
6\end{array}$ & & \\
\hline & .70 & $\begin{array}{l}2 \\
3 \\
4 \\
5 \\
6\end{array}$ & & \\
\hline & .90 & $\begin{array}{l}2 \\
3 \\
4 \\
5 \\
6\end{array}$ & & \\
\hline \multirow{3}{*}{$\mathrm{N}=200$} & .50 & $\begin{array}{l}2 \\
3 \\
4 \\
5 \\
6\end{array}$ & & \\
\hline & .70 & $\begin{array}{l}2 \\
3 \\
4 \\
5 \\
6\end{array}$ & & \\
\hline & .90 & $\begin{array}{l}2 \\
3 \\
4 \\
5 \\
6\end{array}$ & & \\
\hline \multirow{3}{*}{$N=500$} & .50 & $\begin{array}{l}2 \\
3 \\
4 \\
5 \\
6\end{array}$ & & \\
\hline & .70 & $\begin{array}{l}2 \\
3 \\
4 \\
5 \\
6\end{array}$ & & \\
\hline & .90 & $\begin{array}{l}2 \\
3 \\
4 \\
5 \\
6\end{array}$ & & \\
\hline
\end{tabular}


Table 2

Example of Population Variance-Covariance Matrix $(\mathrm{p} / \mathrm{m}=2$, Free Loadings $=0.5)$

$\begin{array}{lllllll}1.0 & & & & & \\ 0.25 & 1.0 & & & & \\ 0.0 & 0.0 & 1.0 & & & \\ 0.0 & 0.0 & 0.25 & 1.0 & & \\ 0.25 & 0.25 & 0.25 & 0.25 & 1.75 & \\ 0.125 & 0.125 & 0.125 & 0.125 & 0.5 & 1.0\end{array}$




\section{Data Analyses}

\section{(1) Nonconvergence and Boundary cases}

Frequency of nonconvergence and boundary cases are reported. If a sample did not converge with either GLS or ML or both, this sample was excluded from any further analysis.

\section{(2) Summary Statistics}

For $\chi^{2}$, the percentage of significant $\chi^{2}$ values with $\mathrm{p}<.05$ (i.e. those rejecting the null hypothesis) is reported as a summary statistic for each condition. For the other indices, the means and standard deviations for the indices are reported as summary statistics.

(3) Effects

A series of four-way Analyses of Variance were conducted to assess the following main effects and interaction effects on each of the fourteen fit indices (seven indices, both corrected and uncorrected for parsimony): (1) Main Effects: Sample Size (N), Loading size (L), Number of indicators per factor (k), i.e. p/m, Estimation Method (E); (2) Interaction Effects: $\mathrm{N} \times \mathrm{L}, \mathrm{N} \times \mathrm{k}, \mathrm{N} \times \mathrm{E}, \mathrm{L} \times \mathrm{k}, \mathrm{L} \times \mathrm{E}, \mathrm{k} \times \mathrm{E}$ and the higher order interactions. The critical value was set at $\alpha=0.01$ for all ANOVA tests. Because of the extreme power of this study, only results with $\eta^{2} \geq 0.05$ will be interpreted. 


\section{RESULTS}

\section{Non-convergence and boundary cases}

Non-convergence. The frequency of nonconvergence occurring among 100 replicates is summarized in Table 3. The large number of non-convergent cases happened under the conditions of $\mathrm{N}=50, \mathrm{~L}=.5$, the low sample size, low loading condition. This is consistent with results reported in a factor analysis context (e.g., Velicer \& Fava, 1987, 1993). The frequency of non-convergence ranged from 7 to 63 across five $\mathrm{p} / \mathrm{m}$ ratio models for the GLS solution and 3 to 73 for the ML solution. However, once the sample size reached 100 or the loading size reached .70 , non-convergent cases were rare. GLS produces slightly more nonconvergent cases than ML does, in general. Nonconvergent cases were deleted before performing any further analysis.

Boundary cases. The frequency of boundary cases occurring among 100 replications is summarized in Table 4. A clear relationships between the occurrence of boundary cases and sample size, loading size, and the number of indicators per factor can be seen. The occurrence of boundary cases decreased 1) when $N$ increased; 2) when L increased; and 3) when $\mathrm{p} / \mathrm{m}$ increased. These findings are consistent with previous findings ( Boomsma, 1982; Anderson \& Gerbing, 1984; Gerbing \& Anderson, 1987; Velicer \& Fava, 1987, 1993).

While the trends for both GLS and ML are the same, there are more boundary cases from the GLS solutions than from the ML solutions. When $\mathrm{p} / \mathrm{m}$ increases, there is a bigger drop in the number of boundary cases for the ML solutions than with GLS solutions. 
Table 3

Frequency distribution of non-convergent cases among 100 replicates across all conditions

\begin{tabular}{|c|c|c|c|c|c|c|c|c|c|}
\hline & $\mathrm{p} / \mathrm{m}$ & $\mathrm{N}=50$ & $\mathrm{~N}=100$ & $\begin{array}{r}\text { GLS } \\
N=200\end{array}$ & $\mathrm{~N}=500$ & $\mathrm{~N}=50$ & $\mathrm{~N}=100$ & $\begin{array}{c}\text { ML } \\
\mathrm{N}=200\end{array}$ & $\mathrm{~N}=500$ \\
\hline \multirow{5}{*}{$\mathrm{L}=.50$} & 2 & 7 & 3 & 0 & 0 & 3 & 1 & 0 & 0 \\
\hline & 3 & 31 & 0 & 1 & 0 & 42 & 1 & 0 & 0 \\
\hline & 4 & 10 & 1 & 0 & 0 & 5 & 0 & 0 & 0 \\
\hline & 5 & 63 & 2 & 0 & 0 & 73 & 0 & 0 & 0 \\
\hline & 6 & 22 & 3 & 0 & 0 & 1 & 0 & 0 & 0 \\
\hline \multirow{5}{*}{$L=.70$} & 2 & 9 & 0 & 0 & 0 & 0 & 0 & 0 & 0 \\
\hline & 3 & 0 & 0 & 0 & 0 & 0 & 0 & 0 & 0 \\
\hline & 4 & I & 0 & 0 & 0 & 0 & 0 & 0 & 0 \\
\hline & 5 & 2 & 0 & 0 & 0 & 0 & 0 & 0 & 0 \\
\hline & 6 & 6 & 0 & 0 & 0 & 0 & 0 & 0 & 0 \\
\hline \multirow{5}{*}{$\mathrm{L}=.90$} & 2 & 0 & 0 & 0 & 0 & 1 & 0 & 0 & 0 \\
\hline & 3 & 0 & 0 & 0 & 0 & 0 & 0 & 0 & 0 \\
\hline & 4 & 0 & 0 & 0 & 0 & 0 & 0 & 0 & 0 \\
\hline & 5 & 2 & 0 & 0 & 0 & 0 & 0 & 0 & 0 \\
\hline & 6 & 5 & 0 & 0 & 0 & 0 & 0 & 0 & 0 \\
\hline
\end{tabular}


Table 4

Frequency distribution of boundary cases

among 100 replicates across all conditions

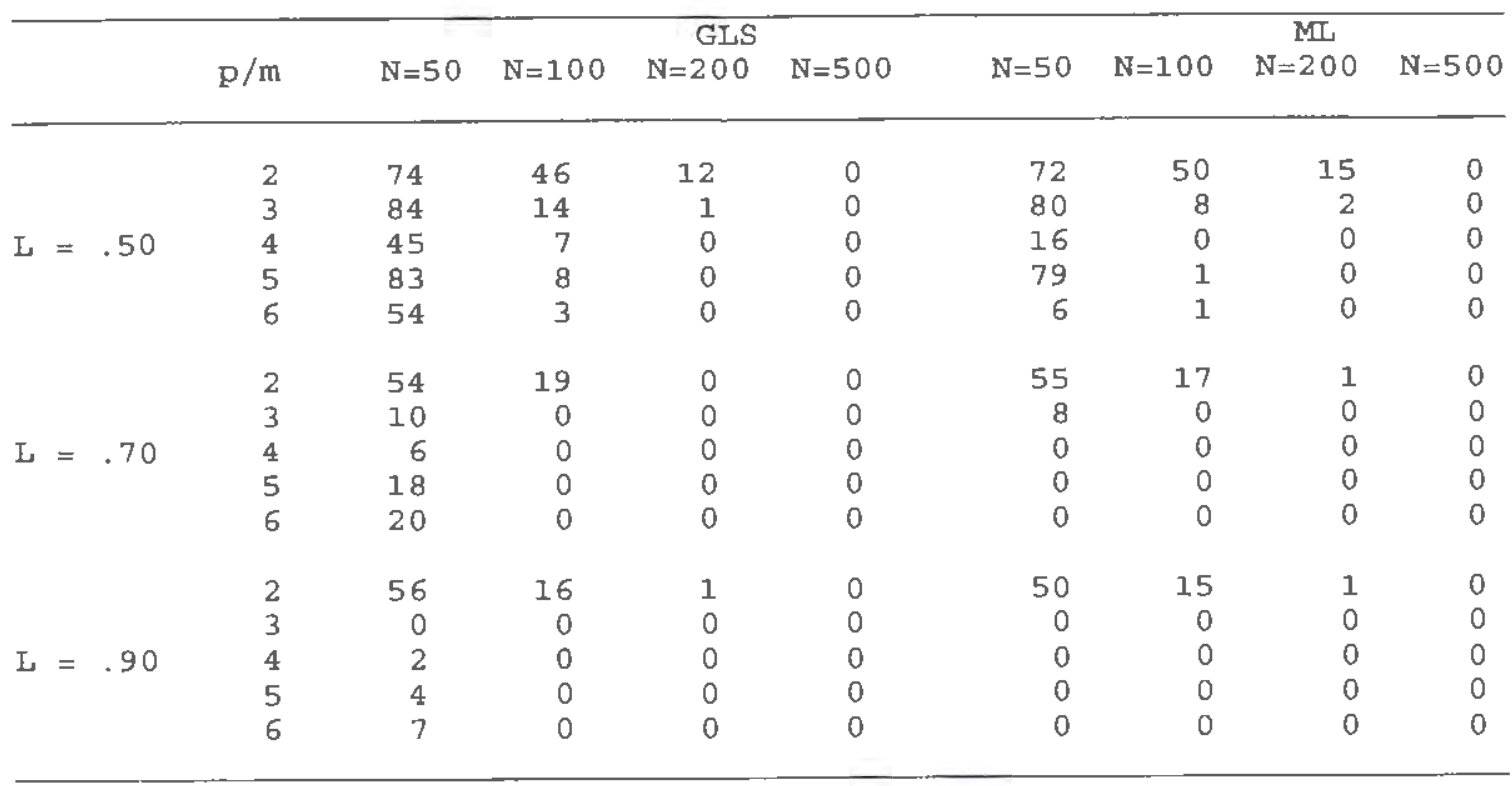




\section{Fit Indices}

\section{Chi-square $\left(x^{2}\right)$}

The percentage of significant $\chi^{2}$ values under each condition is summarized in Table 5. The $\alpha$ level chosen was .05.

Under GLS estimation, the null hypothesis is rarely rejected. The percentage of significant $\chi^{2}$ values ranged from 0.0 to 6.0 with one exception. With 100 replications, the expected percentage rejected is 5.0. No distinctive patterns can be detected, i.e. none of the factors seems to have a strong influence on the outcome. The overall average percentage of significant $\chi^{2}$ values was 2.58 for GLS, an underestimate.

The results from ML followed a very different pattern. Sample size had a strong effect on the $\chi^{2}$ values. However, the findings were contrary to a common criticism in applications, i.e., $\chi^{2}$ tends to be significant simply because the sample size is large. The result was in the other direction, .i.e., the test works better when sample size increases. For example, the percentage of significant $\chi^{2}$ values dropped from 39.4 to 6.0 when sample size increased from 50 to 500 under the condition of $\mathrm{p} / \mathrm{m}=6, \mathrm{~L}=0.5$. The $\mathrm{p} / \mathrm{m}$ ratio also had a very strong effect on $\chi^{2}$. This effect is strongly interactive with sample size. When $\mathrm{p} / \mathrm{m}$ becomes large, the percentage of significant $\chi^{2}$ values increased, under $\mathrm{N}=100$ and $\mathrm{L}=0.5$. The percentage of significant $\chi^{2}$ values ranged from 3.0 to 21.0 when $\mathrm{p} / \mathrm{m}$ increased from 2 to 6 . However, this situation improved dramatically when sample size increased. When $\mathrm{N}$ reached 500 , no $\mathrm{p} / \mathrm{m}$ effect was detected. The Loading size seems to have little influence on $\chi^{2}$. Overall the average percentage of rejection was 11.48 with $\mathrm{ML}$, an overestimate. 
Table 5

Percentage of significant Chi-square $\left(x^{2}\right)$ values $(\alpha=0.05)$ across all conditions

\begin{tabular}{|c|c|c|c|c|c|c|c|c|c|}
\hline & & & GLS & & & & $\mathrm{ML}$ & & \\
\hline & $\mathrm{p} / \mathrm{m}$ & $\mathrm{N}=50$ & $\mathrm{~N}=100$ & $\mathrm{~N}=200$ & $N=500$ & $N=50$ & $\mathrm{~N}=100$ & $\mathrm{~N}=200$ & $\mathrm{~N}=500$ \\
\hline & 2 & 3.2 & 0 & 5.0 & 6.0 & 10.3 & 3.0 & 6.0 & 6.0 \\
\hline & 3 & 11.6 & 1.0 & 4.0 & 1.0 & 36.2 & 5.1 & 6.0 & 1.0 \\
\hline $\mathrm{L}=.50$ & 4 & 0 & 2.0 & 0 & 2.0 & 20.0 & 8.0 & 3.0 & 3.0 \\
\hline & 5 & 0 & 4.1 & 4.0 & 3.0 & 25.9 & 10.0 & 10.0 & 6.0 \\
\hline & 6 & 0 & 1.0 & 2.0 & 5.0 & 39.4 & 21.0 & 12.0 & 6.0 \\
\hline & 2 & 0 & 3.0 & 4.0 & 5.0 & 6.0 & 5.0 & 4.0 & 5.0 \\
\hline & 3 & 1.0 & 0 & 4.0 & 0 & 8.0 & 4.0 & 6.0 & 2.0 \\
\hline$L=.70$ & 4 & 1.0 & 3.0 & 1.0 & 3.0 & 21.0 & 11.0 & 4.0 & 4.0 \\
\hline & 5 & 1.0 & 4.0 & 4.0 & 4.0 & 31.0 & 11.0 & 10.0 & 6.0 \\
\hline & 6 & 0 & 1.0 & 2.0 & 4.0 & 38.0 & 22.0 & 12.0 & 5.0 \\
\hline & 2 & 3.0 & 6.0 & 2.0 & 6.0 & 8.1 & 6.0 & 3.0 & 5.0 \\
\hline & 3 & 1.0 & 0 & 3.0 & 4.0 & 9.0 & 8.0 & 6.0 & 4.0 \\
\hline$L=-90$ & 4 & 2.0 & 3.0 & 3.0 & 4.0 & 22.0 & 9.0 & 6.0 & 3.0 \\
\hline & 5 & 1.0 & 4.0 & 5.0 & 3.0 & 34.0 & 15.0 & 9.0 & 6.0 \\
\hline & 6 & 0 & 1.0 & 1.0 & 3.0 & 39.0 & 24.0 & 13.0 & 7.0 \\
\hline
\end{tabular}


Table 6

Percentage of significant Parsimoniously adjusted Chi-scuare $(\mathrm{PX})$ values $(\alpha=0.05)$ across all conditions

\begin{tabular}{|c|c|c|c|c|c|c|c|c|c|}
\hline & \multirow[b]{2}{*}{$\mathrm{p} / \mathrm{m}$} & \multicolumn{4}{|c|}{ GLS } & \multicolumn{4}{|c|}{ ML } \\
\hline & & $\mathrm{N}=50$ & $N=1.00$ & $\mathrm{~N}=200$ & $\mathrm{~N}=500$ & $\mathrm{~N}=50$ & $\mathrm{~N}=100$ & $\mathrm{~N}=200$ & $\mathrm{~N}=500$ \\
\hline \multirow{5}{*}{$\mathrm{L}=.50$} & 2 & 0 & 0 & 0 & 0 & 0 & 0 & 0 & 0 \\
\hline & 3 & 0 & 0 & 0 & 0 & 25.9 & 0 & 0 & 0 \\
\hline & 4 & 0 & 0 & 0 & 0 & 1.1 & 0 & 0 & 0 \\
\hline & 5 & 0 & 0 & 1.0 & 0 & 0 & 1.0 & 1.0 & 0 \\
\hline & 6 & 0 & 0 & 0 & 0 & 4.0 & 1.0 & 0 & 0 \\
\hline \multirow{5}{*}{$L=.70$} & 2 & 0 & 0 & 0 & 0 & 0 & 0 & 0 & 0 \\
\hline & 3 & 0 & 0 & 0 & 0 & 1.0 & 0 & 0 & 0 \\
\hline & 4 & 0 & 0 & 0 & 0 & 1.0 & 0 & 0 & 0 \\
\hline & 5 & 0 & 0 & 1.0 & 0 & 1.0 & 1.0 & 1.0 & 0 \\
\hline & 6 & 0 & 0 & 0 & 0 & 6.0 & 2.0 & 0 & 0 \\
\hline \multirow{5}{*}{$L=.90$} & 2 & 0 & 0 & 0 & 0 & 0 & 0 & 0 & 0 \\
\hline & 3 & 0 & 0 & 0 & 0 & 1.0 & 0 & 0 & 0 \\
\hline & 4 & 0 & 0 & 0 & 0 & 3.0 & 1.0 & 0 & 0 \\
\hline & 5 & 0 & 0 & 0 & 0 & 1.0 & 1.0 & 1.0 & 0 \\
\hline & 6 & 0 & 0 & 0 & 0 & 7.0 & 2.0 & 0 & 0 \\
\hline
\end{tabular}


The overestimation effect was overcome by using James's Parsimony Index. The results of $\mathbf{P} \chi^{2}$ is presented in Table 6 . We can see that $\mathbf{P} \chi^{2}$ is rarely significant across all conditions except in one cell. The average percentage for the GLS estimation was 0.03 , and the average percentage for the ML was 1.07 . Therefore, the parsimoniously corrected Chi-square test would be a very conservative test, badly underestimating the true $\alpha$ level. $\mathbf{P} \chi^{2}$ will be discussed in more detail in the Discussion section.

\section{Normed Fit Index (NFT)}

The Means and Standard Deviations are reported in Table 7 for the NFI estimates. The results are also illustrated in Figure 3 (GLS results) and Figure 4 (ML results). The MANOVA results show that all the factors had a significant effect on NFI. This is summarized in Appendix A, Table A-1.

Magnitude of effects. The main effect of sample size is $F_{(3,5744)}=1725, \eta^{2}$ is 0.11. The main effect of loading is $\mathrm{F}_{(2,5744)}=2869.01, \eta^{2}$ is 0.13 . The main effect of estimation method is $F_{(1,5744)}=14402.41, \eta^{2}$ is 0.21 . The interaction between estimation and sample size is $F_{(3,24)}=1377.08, \eta^{2}=0.08$. All the other main and interaction effects were also significant but did not reach required $\eta^{2}$ level.

Variability. The Standard Deviations ranged from 0.0001 to 0.0152 across all conditions for GLS solutions and from 0.0017 to 0.7687 for ML solutions. The variability of NFI decreased when $\mathrm{N}$ increased or $\mathrm{L}$ increased. The ratio of $\mathrm{p} / \mathrm{m}$ does not appear to affect the variability very much. 
Table 7

Means and standard deviations for the Normed Fit Index

\begin{tabular}{|c|c|c|c|c|c|c|c|c|}
\hline \multirow{2}{*}{\multicolumn{2}{|c|}{$\begin{array}{c}\text { Sample } \\
\text { Size }\end{array}$}} & \multirow[b]{2}{*}{$\begin{array}{l}\text { p/m } \\
\text { ratio }\end{array}$} & \multicolumn{3}{|c|}{ GLS } & \multicolumn{3}{|c|}{ MI } \\
\hline & & & Mean & $\begin{array}{l}\text { Standard } \\
\text { Deviation }\end{array}$ & $\begin{array}{l}\text { Number } \\
\text { cases }\end{array}$ & Mean & $\begin{array}{l}\text { Standard } \\
\text { Deviation }\end{array}$ & $\begin{array}{l}\text { Number } \\
\text { cases }\end{array}$ \\
\hline \multirow{4}{*}{$\begin{array}{l}\text { Loading } \\
=0.50\end{array}$} & 50 & $\begin{array}{l}2 \\
3 \\
4 \\
5 \\
6\end{array}$ & $\begin{array}{l}0.9768 \\
0.9546 \\
0.9573 \\
0.9530 \\
0.9582\end{array}$ & $\begin{array}{l}0.0092 \\
0.0152 \\
0.0063 \\
0.0091 \\
0.0057\end{array}$ & $\begin{array}{l}93 \\
69 \\
90 \\
37 \\
78\end{array}$ & $\begin{array}{l}0.7710 \\
0.5488 \\
0.5769 \\
0.5128 \\
0.4740\end{array}$ & $\begin{array}{l}0.1075 \\
0.7687 \\
0.0837 \\
0.0746 \\
0.0635\end{array}$ & $\begin{array}{l}97 \\
55 \\
95 \\
27 \\
99\end{array}$ \\
\hline & 100 & $\begin{array}{l}2 \\
3 \\
4 \\
5 \\
6\end{array}$ & $\begin{array}{l}0.9870 \\
0.9742 \\
0.9643 \\
0.9575 \\
0.9528\end{array}$ & $\begin{array}{l}0.0056 \\
0.0059 \\
0.0054 \\
0.0058 \\
0.0050\end{array}$ & $\begin{array}{r}97 \\
100 \\
99 \\
98 \\
97\end{array}$ & $\begin{array}{l}0.8681 \\
0.7856 \\
0.7233 \\
0.6789 \\
0.6448\end{array}$ & $\begin{array}{l}0.0703 \\
0.0608 \\
0.0530 \\
0.0572 \\
0.0536\end{array}$ & $\begin{array}{r}99 \\
99 \\
100 \\
100 \\
100\end{array}$ \\
\hline & 200 & $\begin{array}{l}2 \\
3 \\
4 \\
5 \\
6\end{array}$ & $\begin{array}{l}0.9925 \\
0.9848 \\
0.9780 \\
0.9715 \\
0.9671\end{array}$ & $\begin{array}{l}0.0038 \\
0.0042 \\
0.0034 \\
0.0041 \\
0.0037\end{array}$ & $\begin{array}{r}100 \\
99 \\
100 \\
100 \\
100\end{array}$ & $\begin{array}{l}0.9249 \\
0.8764 \\
0.8413 \\
0.8057 \\
0.7884\end{array}$ & $\begin{array}{l}0.0387 \\
0.0372 \\
0.0281 \\
0.0339 \\
0.0307\end{array}$ & $\begin{array}{l}100 \\
100 \\
100 \\
100 \\
100\end{array}$ \\
\hline & 500 & $\begin{array}{l}2 \\
3 \\
4 \\
5 \\
6\end{array}$ & $\begin{array}{l}0.9971 \\
0.9932 \\
0.9899 \\
0.9870 \\
0.9841\end{array}$ & $\begin{array}{l}0.0017 \\
0.0018 \\
0.0017 \\
0.0020 \\
0.0021\end{array}$ & $\begin{array}{l}100 \\
100 \\
100 \\
100 \\
100\end{array}$ & $\begin{array}{l}0.9712 \\
0.9445 \\
0.9284 \\
0.9139 \\
0.9022\end{array}$ & $\begin{array}{l}0.0170 \\
0.0153 \\
0.0132 \\
0.0144 \\
0.0145\end{array}$ & $\begin{array}{l}100 \\
100 \\
100 \\
100 \\
100\end{array}$ \\
\hline \multirow{4}{*}{$\begin{array}{l}\text { Loading } \\
=0.70\end{array}$} & 50 & $\begin{array}{l}2 \\
3 \\
4 \\
5 \\
5\end{array}$ & $\begin{array}{l}0.9882 \\
0.9812 \\
0.9783 \\
0.9780 \\
0.9798\end{array}$ & $\begin{array}{l}0.0053 \\
0.0048 \\
0.0046 \\
0.0043 \\
0.0041\end{array}$ & $\begin{array}{r}100 \\
100 \\
99 \\
98 \\
94\end{array}$ & $\begin{array}{l}0.8983 \\
0.8280 \\
0.7776 \\
0.7309 \\
0.7002\end{array}$ & $\begin{array}{l}0.0523 \\
0.0505 \\
0.0497 \\
0.0394 \\
0.0438\end{array}$ & $\begin{array}{l}100 \\
100 \\
100 \\
100 \\
100\end{array}$ \\
\hline & 100 & $\begin{array}{l}2 \\
3 \\
4 \\
5 \\
5\end{array}$ & $\begin{array}{l}0.9927 \\
0.9867 \\
0.9821 \\
0.9791 \\
0.9774\end{array}$ & $\begin{array}{l}0.0033 \\
0.0034 \\
0.0032 \\
0.0035 \\
0.0034\end{array}$ & $\begin{array}{l}100 \\
100 \\
100 \\
100 \\
100\end{array}$ & $\begin{array}{l}0.9473 \\
0.9097 \\
0.8786 \\
0.8543 \\
0.8322\end{array}$ & $\begin{array}{l}0.0268 \\
0.0265 \\
0.0245 \\
0.0269 \\
0.0263\end{array}$ & $\begin{array}{l}100 \\
100 \\
100 \\
100 \\
100\end{array}$ \\
\hline & 200 & $\begin{array}{l}2 \\
3 \\
4 \\
5 \\
6\end{array}$ & $\begin{array}{l}0.9961 \\
0.9921 \\
0.9892 \\
0.9861 \\
0.9842\end{array}$ & $\begin{array}{l}0.0021 \\
0.0023 \\
0.0019 \\
0.0023 \\
0.0022\end{array}$ & $\begin{array}{l}100 \\
100 \\
100 \\
100 \\
100\end{array}$ & $\begin{array}{l}0.9732 \\
0.9531 \\
0.9381 \\
0.9225 \\
0.9129\end{array}$ & $\begin{array}{l}0.0155 \\
0.0141 \\
0.0106 \\
0.0136 \\
0.0128\end{array}$ & $\begin{array}{l}100 \\
100 \\
100 \\
100 \\
100\end{array}$ \\
\hline & 500 & $\begin{array}{l}2 \\
3 \\
4 \\
5 \\
6\end{array}$ & $\begin{array}{l}0.9984 \\
0.9965 \\
0.9950 \\
0.9937 \\
0.9924\end{array}$ & $\begin{array}{l}0.0009 \\
0.0009 \\
0.0009 \\
0.0010 \\
0.0011\end{array}$ & $\begin{array}{l}100 \\
100 \\
100 \\
100 \\
100\end{array}$ & $\begin{array}{l}0.9896 \\
0.9804 \\
0.9744 \\
0.9688 \\
0.9639\end{array}$ & $\begin{array}{l}0.0062 \\
0.0053 \\
0.0046 \\
0.0051 \\
0.0051\end{array}$ & $\begin{array}{l}100 \\
100 \\
100 \\
100 \\
100\end{array}$ \\
\hline \multirow{4}{*}{$\begin{array}{l}\text { Loading } \\
=0.90\end{array}$} & 50 & $\begin{array}{l}2 \\
3 \\
4 \\
5 \\
6\end{array}$ & $\begin{array}{l}0.9978 \\
0.9970 \\
0.9967 \\
0.9968 \\
0.9971\end{array}$ & $\begin{array}{l}0.0013 \\
0.0011 \\
0.0010 \\
0.0008 \\
0.0008\end{array}$ & $\begin{array}{r}100 \\
100 \\
100 \\
98 \\
95\end{array}$ & $\begin{array}{l}0.9592 \\
0.9328 \\
0.9100 \\
0.8868 \\
0.8685\end{array}$ & $\begin{array}{l}0.0218 \\
0.0200 \\
0.0199 \\
0.0160 \\
0.0183\end{array}$ & $\begin{array}{r}99 \\
100 \\
100 \\
100 \\
100\end{array}$ \\
\hline & 100 & $\begin{array}{l}2 \\
3 \\
4 \\
5 \\
6\end{array}$ & $\begin{array}{l}0.9988 \\
0.9979 \\
0.9973 \\
0.9969 \\
0.9967\end{array}$ & $\begin{array}{l}0.0006 \\
0.0006 \\
0.0006 \\
0.0007 \\
0.0007\end{array}$ & $\begin{array}{l}100 \\
100 \\
100 \\
100 \\
100\end{array}$ & $\begin{array}{l}0.9823 \\
0.9680 \\
0.9555 \\
0.9450 \\
0.9341\end{array}$ & $\begin{array}{l}0.0098 \\
0.0091 \\
0.0088 \\
0.0098 \\
0.0090\end{array}$ & $\begin{array}{l}100 \\
100 \\
100 \\
100 \\
100\end{array}$ \\
\hline & 200 & $\begin{array}{l}2 \\
3 \\
4 \\
5 \\
6\end{array}$ & $\begin{array}{l}0.9993 \\
0.9988 \\
0.9984 \\
0.9979 \\
0.9977\end{array}$ & $\begin{array}{l}0.0003 \\
0.0004 \\
0.0003 \\
0.0004 \\
0.0004\end{array}$ & $\begin{array}{l}100 \\
100 \\
100 \\
100 \\
100\end{array}$ & $\begin{array}{l}0.9912 \\
0.9840 \\
0.9782 \\
0.9722 \\
0.9679\end{array}$ & $\begin{array}{l}0.0043 \\
0.0047 \\
0.0036 \\
0.0045 \\
0.0045\end{array}$ & $\begin{array}{l}100 \\
100 \\
100 \\
100 \\
100\end{array}$ \\
\hline & 500 & $\begin{array}{l}2 \\
3 \\
4 \\
5 \\
6\end{array}$ & $\begin{array}{l}0.9997 \\
0.9995 \\
0.9993 \\
0.9991 \\
0.9989\end{array}$ & $\begin{array}{l}0.0002 \\
0.0002 \\
0.0002 \\
0.0001 \\
0.0002\end{array}$ & $\begin{array}{l}100 \\
100 \\
100 \\
100 \\
100\end{array}$ & $\begin{array}{l}0.9963 \\
0.9935 \\
0.9913 \\
0.9893 \\
0.9873\end{array}$ & $\begin{array}{l}0.0020 \\
0.0018 \\
0.0015 \\
0.0017 \\
0.0017\end{array}$ & $\begin{array}{l}100 \\
100 \\
100 \\
100 \\
100\end{array}$ \\
\hline
\end{tabular}




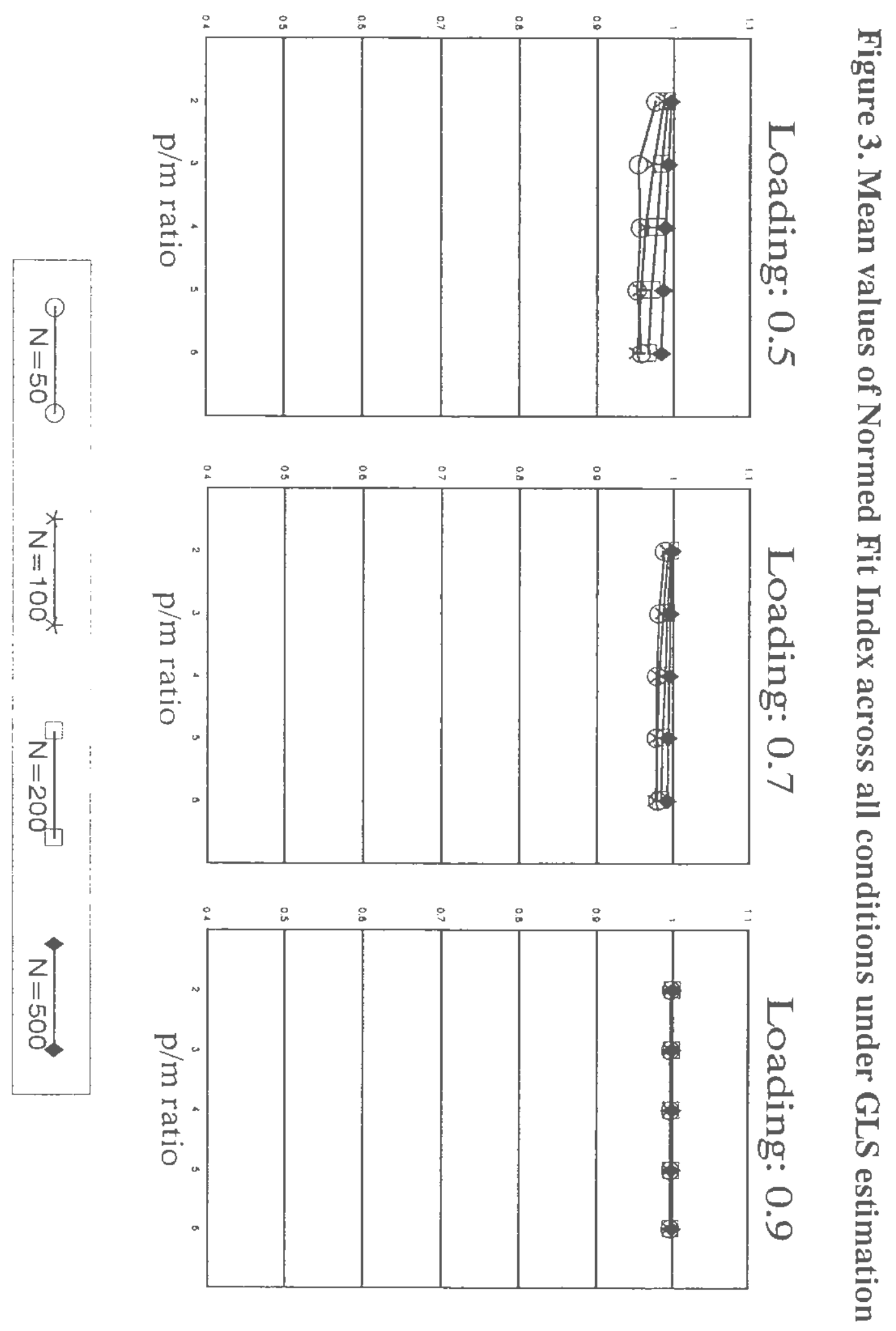




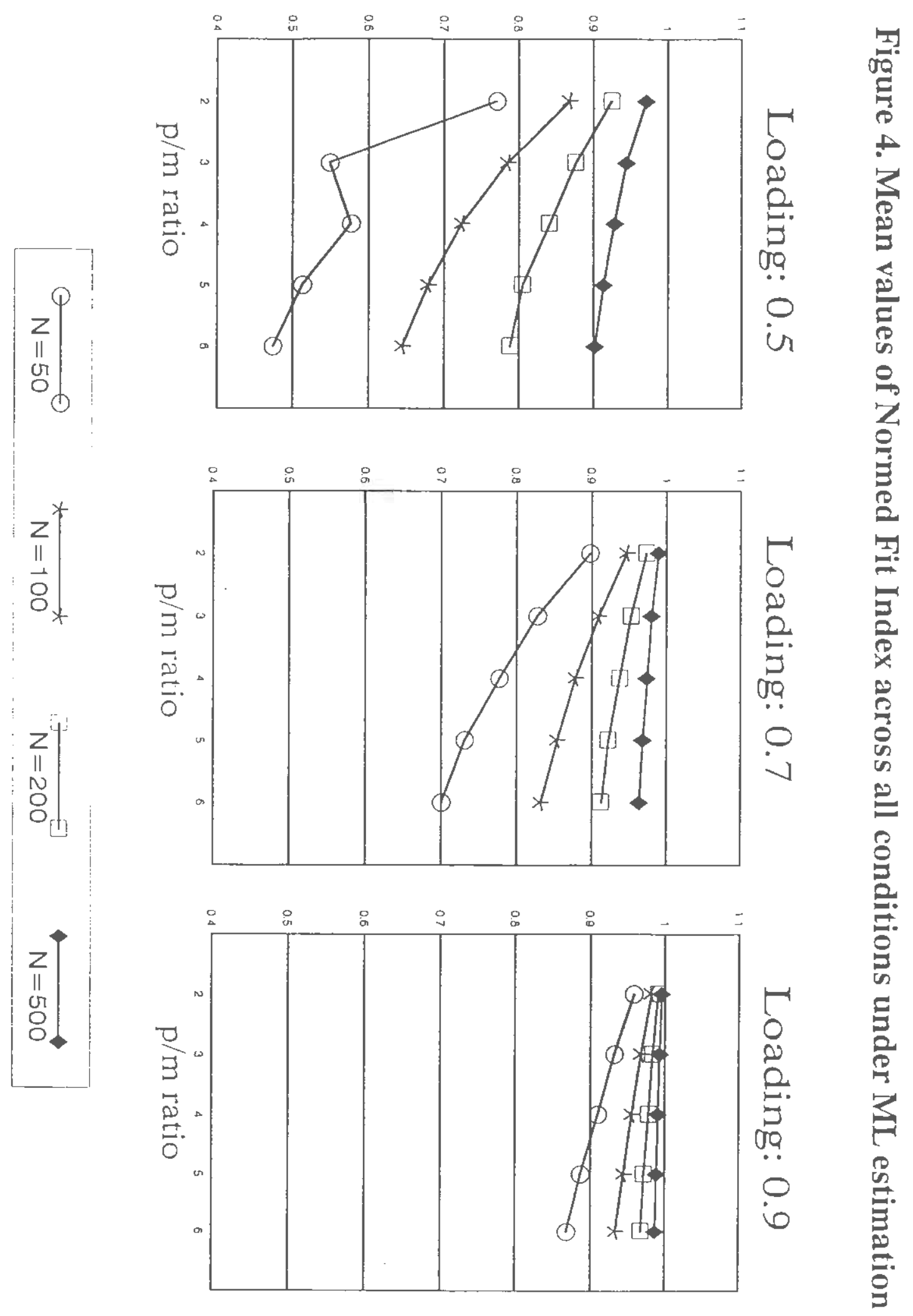


Pattern of performance. In general, NFI was estimation method specific, sample size dependent, and loading size dependent. The two estimators in this study generated quite different results. While NFI values from ML seem to be influenced by every factor, the NFI values from GLS were only slightly influenced by sample size and loading size. The GLS effects were too small to produce noticeable bias (All NFI values for GLS were above the acceptable value of 0.9 across all conditions). Issues regarding GLS estimation are discussed in the Discussion section.

Results from ML showed that sample size appears to have a strong effect on NFI. When $\mathrm{N}=50$, the value of NFI is severely biased downward, especially when small sample size is combined with a low loading and a large $\mathrm{p} / \mathrm{m}$ ratio. The loading size also has a strong effect on NFI. When loadings are low, the value of NFI is seriously biased downward. Only a very big sample size (at least 500 ) can compensate for a low loading of .5. The combined interaction effect of $\mathrm{N}$ and $\mathrm{L}$ is large. Although the effect of the $\mathrm{p} / \mathrm{m}$ ratio on NFI is relatively small $\left(\eta^{2}=0.03\right)$, the pattern of this effect is worth noting. With increased $\mathrm{p} / \mathrm{m}$, the value of $\mathrm{NFI}$ is decreased. When $\mathrm{L}=0.5, \mathrm{~N} \leq 200$, all the values of NFI for $\mathrm{p} / \mathrm{m}=5$ or 6 are below 0.8 . Under the worst condition $(\mathrm{N}=50$, $\mathrm{L}=0.5$ ), NFI ranged from 0.7710 to 0.474 for $\mathrm{p} / \mathrm{m}$ of 2 to 6 accordingly. None of these is above the acceptable value of .90 . This bias was decreased when $\mathrm{N}$ and $\mathrm{L}$ increased. However it did not totally disappeared even with $\mathrm{N}=500$ and $\mathrm{L}=0.9$. This bias may simply be due to the fact that there are relatively more free parameters in a small $\mathrm{p} / \mathrm{m}$ model than in a large $\mathrm{p} / \mathrm{m}$ model, compared to their corresponding number of variables. This issue is discussed in detail in the Discussion section. 


\section{Nonnormed Fit Index (NNFI)}

The Means and Standard Deviations (SDs) are reported in Table 8 for the NNFI estimates. The results are also illustrated in Figure 5 (GLS results) and Figure 6 (ML results). The MANOVA results are summarized in Appendix A, Table A-2.

Magnitude of effects. Although all main effects and 9 out of 11 interaction effects were significant, none of the $\eta^{2}$ s exceeded 0.01 . Therefore, these effects are not considered to be important.

Variability. The SDs ranged from 0.0002 to 0.0233 across all conditions for GLS and from 0.0019 to 0.7571 for ML. Like NFI, the variability decreased when: N increased or when $\mathrm{L}$ increased. Unlike NFI, when $\mathrm{p} / \mathrm{m}$ increased, variability of NNFI decreased as well, however, the influence of $\mathrm{p} / \mathrm{m}$ on variability was much smaller than that of N and L. Contrary to previous studies (e.g. Bentler \& Bonett, 1980), this study did not find that NNFI had a larger variability than that of NFI, in general.

Pattern of performance. NNFI values from GLS solutions are almost perfect under any conditions. Solutions from ML suggest that when sample size is 50 , the NNFI showed a downward bias. This bias is more severe with the increase of $\mathrm{p} / \mathrm{m}$. Note that NNFI is not completely independent of $\mathrm{p} / \mathrm{m}$. However, once sample sizes reach 100 , values of NNFI for all conditions are above the acceptable value of 0.90 . Both loading and $\mathrm{p} / \mathrm{m}$ ratio have small effects on NNFI. However, they were interactive with small sample size when both factors are at the low levels. Once sample size reach 100 , NNFI is almost independent of all three factors. 
Table 8

Means and standard deviationg for the Nonnormed Fit Index

\begin{tabular}{|c|c|c|c|c|c|c|c|c|}
\hline & \multirow[b]{2}{*}{$\underset{\text { Size }}{\text { Sample }}$} & \multirow[b]{2}{*}{$\begin{array}{l}\mathrm{p} / \mathrm{m} \\
\text { ratio }\end{array}$} & \multicolumn{3}{|c|}{ GLS } & \multicolumn{3}{|c|}{ ML } \\
\hline & & & Mean & $\begin{array}{l}\text { Standard } \\
\text { Deviation }\end{array}$ & $\begin{array}{r}\text { Number } \\
\text { cases }\end{array}$ & Mean & $\begin{array}{l}\text { Standard } \\
\text { Deviation }\end{array}$ & $\begin{array}{l}\text { Number } \\
\text { Cases }\end{array}$ \\
\hline \multirow{4}{*}{$\begin{array}{l}\text { Loading } \\
=0.50\end{array}$} & 50 & $\begin{array}{l}2 \\
3 \\
4 \\
5 \\
6\end{array}$ & $\begin{array}{l}1.0012 \\
0.9968 \\
1.0104 \\
1.0074 \\
1.0099\end{array}$ & $\begin{array}{l}0.0231 \\
0.0233 \\
0.0131 \\
0.0126 \\
0.0074\end{array}$ & $\begin{array}{l}93 \\
69 \\
90 \\
37 \\
78\end{array}$ & $\begin{array}{l}0.9536 \\
0.9800 \\
0.9235 \\
0.8740 \\
0.8216\end{array}$ & $\begin{array}{l}0.558 .7 \\
0.7571 \\
0.2775 \\
0.1867 \\
0.1352\end{array}$ & $\begin{array}{l}97 \\
55 \\
95 \\
27 \\
99\end{array}$ \\
\hline & 100 & $\begin{array}{l}2 \\
3 \\
4 \\
5 \\
6\end{array}$ & $\begin{array}{l}1.0030 \\
1.0048 \\
1.0034 \\
1.0046 \\
1.0032\end{array}$ & $\begin{array}{l}0.0124 \\
0.0102 \\
0.0095 \\
0.0091 \\
0.0069\end{array}$ & $\begin{array}{r}97 \\
100 \\
99 \\
98 \\
97\end{array}$ & $\begin{array}{l}1.0151 \\
1.0179 \\
0.9763 \\
0.9719 \\
0.9445\end{array}$ & $\begin{array}{l}0.2210 \\
0.1409 \\
0.1032 \\
0.1034 \\
0.0820\end{array}$ & $\begin{array}{r}99 \\
99 \\
100 \\
100 \\
100\end{array}$ \\
\hline & 200 & $\begin{array}{l}2 \\
3 \\
4 \\
5 \\
6\end{array}$ & $\begin{array}{l}1.0003 \\
1.0014 \\
1.0011 \\
1.0009 \\
1.0013\end{array}$ & $\begin{array}{l}0.0086 \\
0.0065 \\
0.0048 \\
0.0057 \\
0.0049\end{array}$ & $\begin{array}{r}100 \\
99 \\
100 \\
100 \\
100\end{array}$ & $\begin{array}{l}1.0005 \\
1.0049 \\
0.9937 \\
0.9886 \\
0.9890\end{array}$ & $\begin{array}{l}0.1082 \\
0.0659 \\
0.0408 \\
0.0475 \\
0.0425\end{array}$ & $\begin{array}{l}100 \\
100 \\
100 \\
100 \\
100\end{array}$ \\
\hline & 500 & $\begin{array}{l}2 \\
3 \\
4 \\
5 \\
6\end{array}$ & $\begin{array}{l}1.0005 \\
1.0002 \\
1.0001 \\
1.0004 \\
1.0003\end{array}$ & $\begin{array}{l}0.0037 \\
0.0026 \\
0.0022 \\
0.0025 \\
0.0024\end{array}$ & $\begin{array}{l}100 \\
100 \\
100 \\
100 \\
100\end{array}$ & $\begin{array}{l}1.0052 \\
1.0005 \\
0.9981 \\
0.9993 \\
0.9991\end{array}$ & $\begin{array}{l}0.0400 \\
0.0228 \\
0.0164 \\
0.0184 \\
0.0164\end{array}$ & $\begin{array}{l}100 \\
100 \\
100 \\
100 \\
100\end{array}$ \\
\hline \multirow{4}{*}{$\begin{array}{l}\text { Loading } \\
=0.70\end{array}$} & 50 & $\begin{array}{l}2 \\
3 \\
4 \\
5 \\
6\end{array}$ & $\begin{array}{l}1.0043 \\
1.0047 \\
1.0040 \\
1.0041 \\
1.0042\end{array}$ & $\begin{array}{l}0.0130 \\
0.0074 \\
0.0066 \\
0.0049 \\
0.0034\end{array}$ & $\begin{array}{r}100 \\
100 \\
99 \\
90 \\
94\end{array}$ & $\begin{array}{l}0.9974 \\
0.9752 \\
0.9584 \\
0.9370 \\
0.9259\end{array}$ & $\begin{array}{l}0.1517 \\
0.0084 \\
0.0824 \\
0.0594 \\
0.0567\end{array}$ & $\begin{array}{l}100 \\
100 \\
100 \\
100 \\
100\end{array}$ \\
\hline & 100 & $\begin{array}{l}2 \\
3 \\
4 \\
5 \\
6\end{array}$ & $\begin{array}{l}1.0016 \\
1.0022 \\
1.0014 \\
1.0019 \\
1.0013\end{array}$ & $\begin{array}{l}0.0077 \\
0.0051 \\
0.0046 \\
0.0044 \\
0.0032\end{array}$ & $\begin{array}{l}100 \\
100 \\
100 \\
100 \\
100\end{array}$ & $\begin{array}{l}1.0030 \\
1.0001 \\
0.9899 \\
0.9871 \\
0.9784\end{array}$ & $\begin{array}{l}0.0653 \\
0.0431 \\
0.0354 \\
0.0344 \\
0.0290\end{array}$ & $\begin{array}{l}100 \\
100 \\
100 \\
100 \\
100\end{array}$ \\
\hline & 200 & $\begin{array}{l}2 \\
3 \\
4 \\
5 \\
6\end{array}$ & $\begin{array}{l}1.0007 \\
1.0006 \\
1.0005 \\
1.0003 \\
1.0005\end{array}$ & $\begin{array}{l}0.0045 \\
0.0033 \\
0.0023 \\
0.0027 \\
0.0023\end{array}$ & $\begin{array}{l}100 \\
100 \\
100 \\
100 \\
100\end{array}$ & $\begin{array}{l}1.0022 \\
1.0003 \\
0.9973 \\
0.9955 \\
0.9956\end{array}$ & $\begin{array}{l}0.0341 \\
0.0211 \\
0.0136 \\
0.0161 \\
0.0148\end{array}$ & $\begin{array}{l}100 \\
100 \\
100 \\
100 \\
100\end{array}$ \\
\hline & 500 & $\begin{array}{l}2 \\
3 \\
4 \\
5 \\
6\end{array}$ & $\begin{array}{l}1.0004 \\
1.0001 \\
1.0001 \\
1.0002 \\
1.0001\end{array}$ & $\begin{array}{l}0.0021 \\
0.0013 \\
0.0011 \\
0.0012 \\
0.0011\end{array}$ & $\begin{array}{l}100 \\
100 \\
100 \\
100 \\
100\end{array}$ & $\begin{array}{l}1.0022 \\
0.9999 \\
0.9995 \\
0.9998 \\
0.9997\end{array}$ & $\begin{array}{l}0.0139 \\
0.0076 \\
0.0056 \\
0.0062 \\
0.0055\end{array}$ & $\begin{array}{l}100 \\
100 \\
100 \\
100 \\
100\end{array}$ \\
\hline \multirow{4}{*}{$\begin{array}{l}\text { Loading } \\
=0.90\end{array}$} & 50 & $\begin{array}{l}2 \\
3 \\
4 \\
5 \\
6\end{array}$ & $\begin{array}{r}1.0001 \\
1.0006 \\
1.0005 \\
1.0006 \\
1.0006\end{array}$ & $\begin{array}{l}0.0023 \\
0.0011 \\
0.0010 \\
0.0007 \\
0.0005\end{array}$ & $\begin{array}{r}100 \\
100 \\
100 \\
98 \\
95\end{array}$ & $\begin{array}{l}0.9858 \\
0.9894 \\
0.9848 \\
0.9771 \\
0.9730\end{array}$ & $\begin{array}{l}0.0494 \\
0.0300 \\
0.0281 \\
0.0206 \\
0.0204\end{array}$ & $\begin{array}{r}99 \\
100 \\
100 \\
100 \\
100\end{array}$ \\
\hline & 100 & $\begin{array}{l}2 \\
3 \\
4 \\
5 \\
6\end{array}$ & $\begin{array}{l}1.0003 \\
1.0003 \\
1.0002 \\
1.0003 \\
1.0002\end{array}$ & $\begin{array}{l}0.0015 \\
0.0007 \\
0.0007 \\
0.0006 \\
0.0005\end{array}$ & $\begin{array}{l}100 \\
100 \\
100 \\
100 \\
100\end{array}$ & $\begin{array}{l}1.0008 \\
0.9993 \\
0.9962 \\
0.9954 \\
0.9922\end{array}$ & $\begin{array}{l}0.0221 \\
0.0137 \\
0.0119 \\
0.0115 \\
0.0098\end{array}$ & $\begin{array}{l}100 \\
100 \\
100 \\
100 \\
100\end{array}$ \\
\hline & 200 & $\begin{array}{l}2 \\
3 \\
4 \\
5 \\
6\end{array}$ & $\begin{array}{l}1.0001 \\
1.0001 \\
1.0001 \\
1.0000 \\
1.0001\end{array}$ & $\begin{array}{l}0.0007 \\
0.0005 \\
0.0004 \\
0.0004 \\
0.0003\end{array}$ & $\begin{array}{l}100 \\
100 \\
100 \\
100 \\
100\end{array}$ & $\begin{array}{r}1.0008 \\
1.0000 \\
0.9990 \\
0.9982 \\
0.9984\end{array}$ & $\begin{array}{l}0.0095 \\
0.0068 \\
0.0045 \\
0.0053 \\
0.0051\end{array}$ & $\begin{array}{l}100 \\
100 \\
100 \\
100 \\
100\end{array}$ \\
\hline & 500 & $\begin{array}{l}2 \\
3 \\
4 \\
5 \\
6\end{array}$ & $\begin{array}{l}1.0000 \\
1-0000 \\
1-0000 \\
1.0000 \\
1.0000\end{array}$ & $\begin{array}{l}0.0003 \\
0.0002 \\
0.0002 \\
0.0002 \\
0.0002\end{array}$ & $\begin{array}{l}100 \\
100 \\
100 \\
100 \\
100\end{array}$ & $\begin{array}{l}0.9999 \\
1.0000 \\
0.9999 \\
0.9999 \\
0.9999\end{array}$ & $\begin{array}{l}0.0043 \\
0.0025 \\
0.0019 \\
0.0020 \\
0.0019\end{array}$ & $\begin{array}{l}100 \\
100 \\
100 \\
100 \\
100\end{array}$ \\
\hline
\end{tabular}




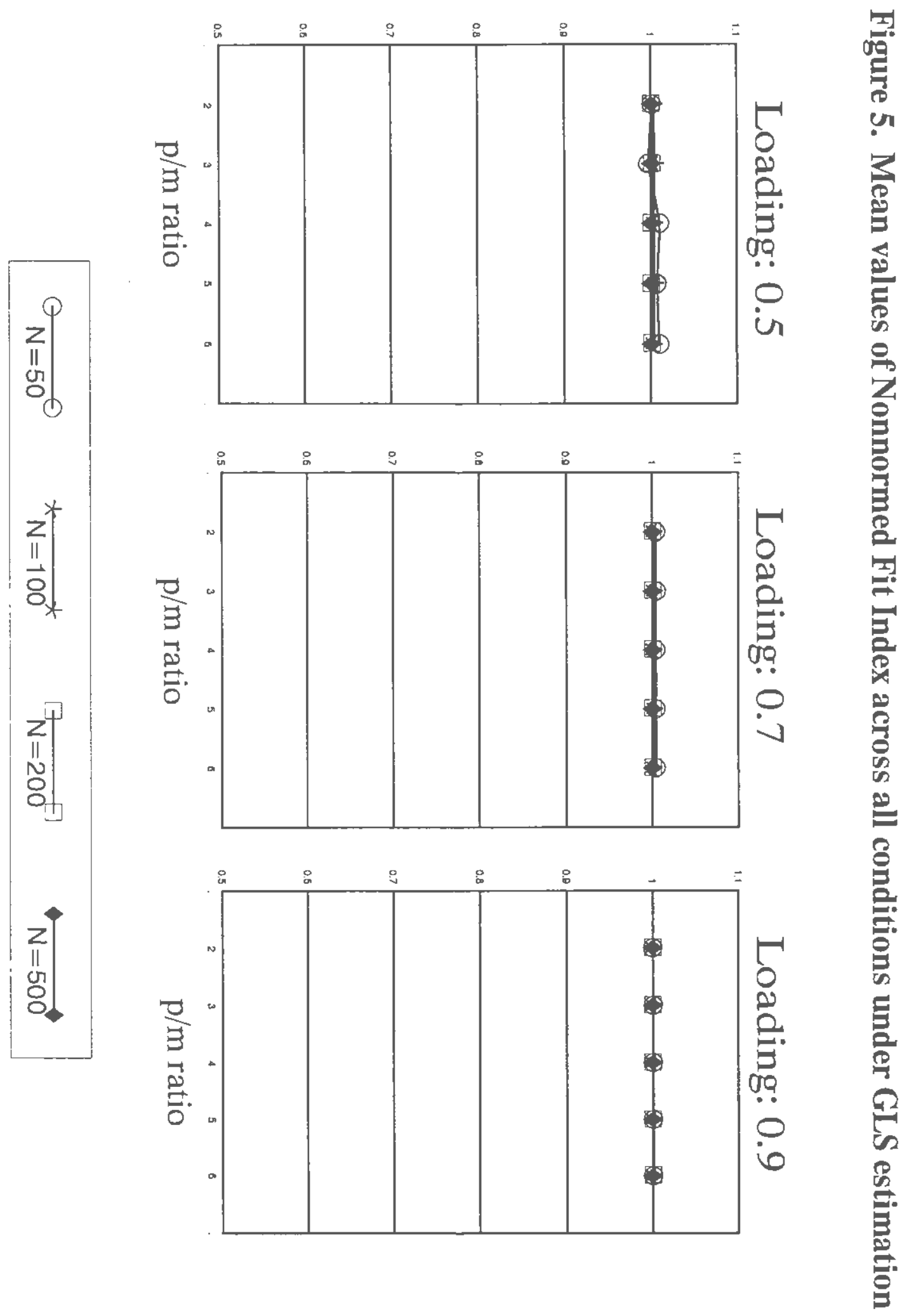



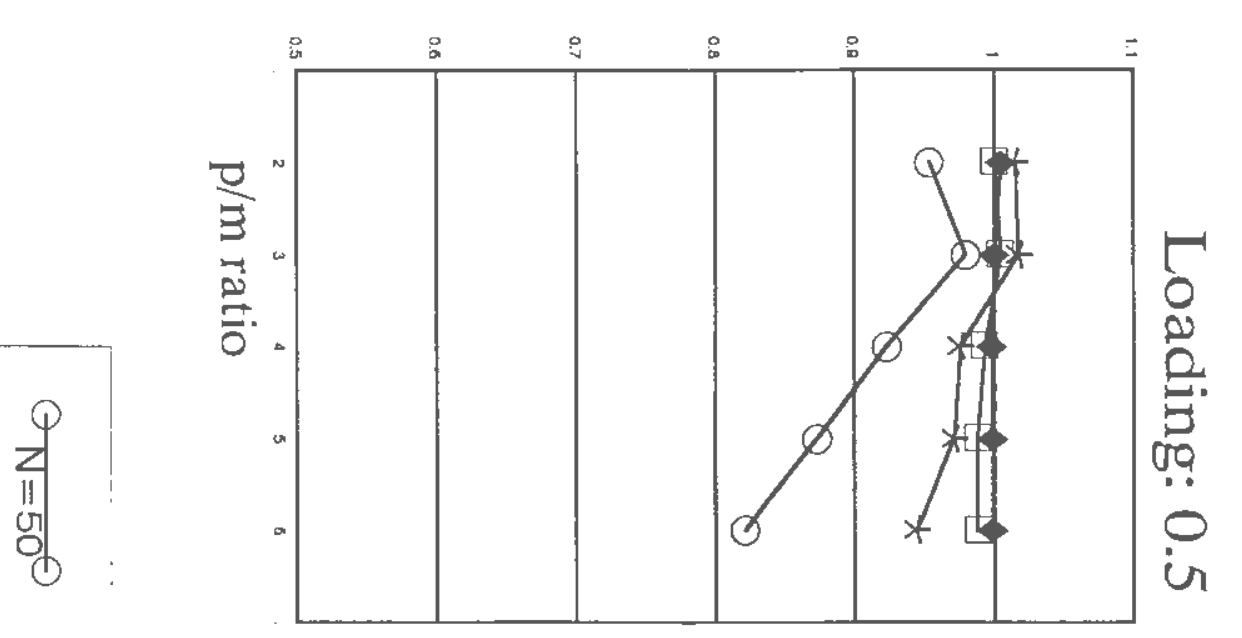

함
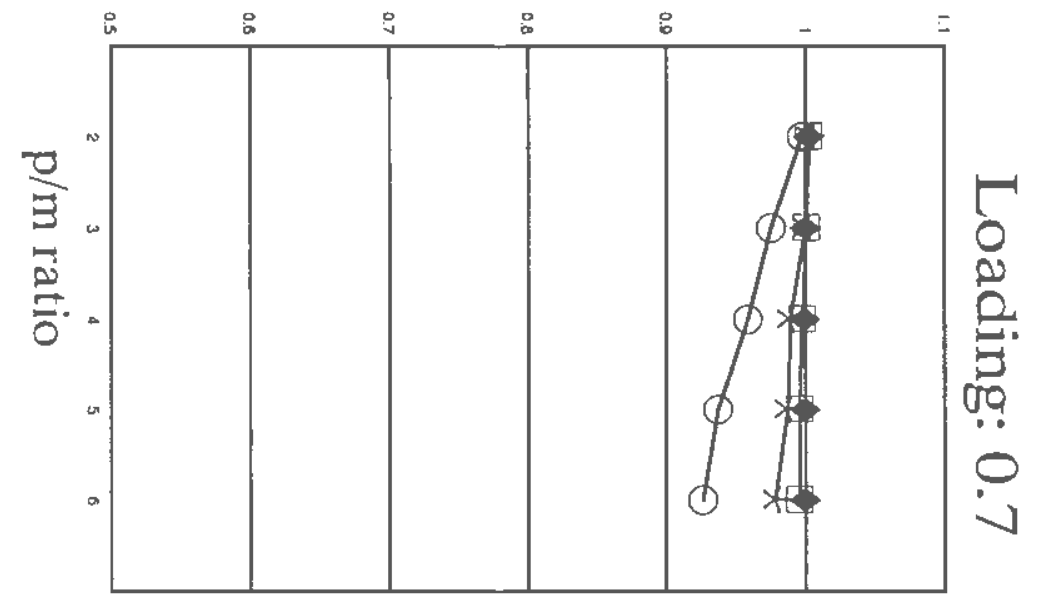

경

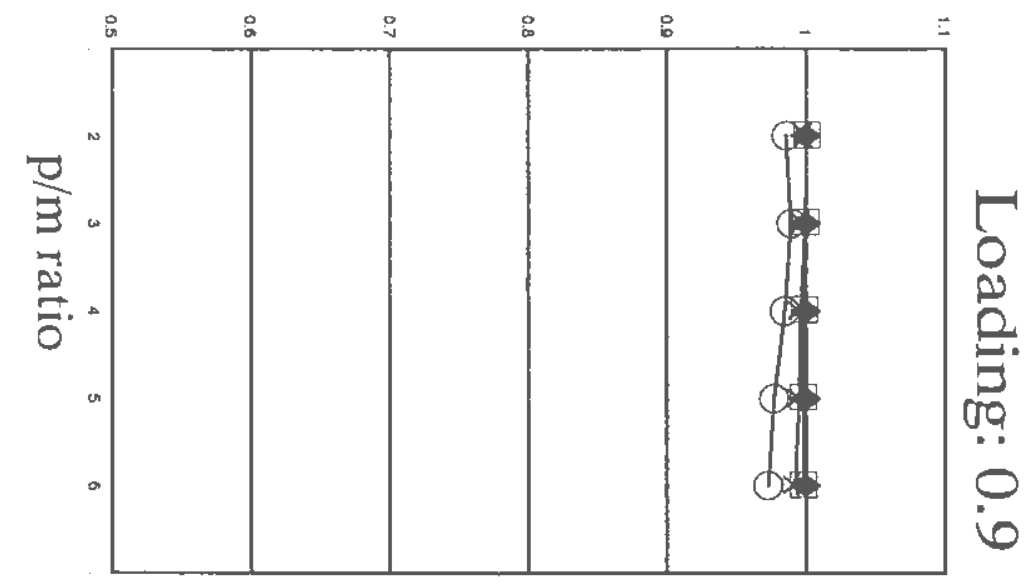

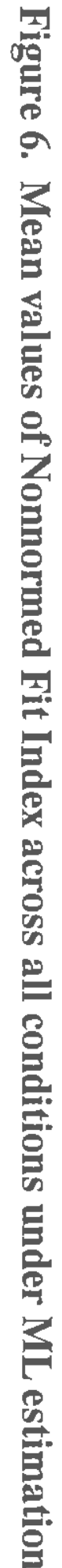




\section{Noncentrality $d$}

The Means and Standard Deviations are reported in Table 9 for estimates of d. The results are also illustrated in Figure 7 (GLS results) and Figure 8 (ML results). The MANOVA results are summarized in Appendix A, Table A-3.

Magnitude of effect. The main effect of estimation method was $F_{(1,5747)}=$ $11409.29, \eta^{2}=0.11$. Among the interaction effects, estimation method by sample size was $\mathrm{F}_{(3,24)}=5143.07, \eta^{2}=0.14$. Estimation method by $\mathrm{p} / \mathrm{m}$ was $\mathrm{F}_{(4.24)}=1937.84, \eta^{2}$ $=0.07$. All other main effects and interaction effects (except the main effect of loading and its interaction effects with sample size ) were also significant but did not reach the required $\eta^{2}$ level of .05 required for interpretation.

Variability. The SDs ranged from 0.0085 to 0.2704 for GLS across all conditions and from 0.0084 to 0.3667 for $\mathrm{ML}$ (except for the condition of $\mathrm{N}=50, \mathrm{~L}=.5$ and $\mathrm{p} / \mathrm{m}=3$, where SD was exceptionally large $(\mathrm{SD}=2.8779))$. The variability of $d$ was strongly influenced by sample size and $\mathrm{p} / \mathrm{m}$ ratio. The variability decreased when $\mathrm{N}$ increased and $\mathrm{p} / \mathrm{m}$ decreased. Loading size had no influence on the variability of this index.

Pattern of Performance. Findings from this study suggest that $d$ is very much estimation method specific. GLS and ML produce substantially different results for $d$. For GLS solutions, almost all the mean values across conditions are negative. $d$ is not completely independent of sample size, particularly when $\mathrm{N}$ is less than 200 (see Figure 7). The $d$ value decreased a great deal when $\mathrm{p} / \mathrm{m}$ increased. However, since $d$ is a parameter of noncentrality, it is determined approximately by $\left(x^{2}-\mathrm{df}\right) / \mathrm{N}$. Therefore, a 
negative sign means that $\chi^{2}$ is smaller than $d f$. Theoretically, this simply represents sampling error under the condition where the alternative distribution does not differ from the null distribution. In this study, since all models are correctly specified, the difference between two distributions should only be due to random error, therefore the extreme and consistent pattern of departure in the negative direction is difficult to understand. This may have more to do with the estimator used than with the index itself (see below). When sample size reach 200 , all values of $d$ are close to 0 , which is the true value for the correct specified model. Loading size had no effect on this index. Although the main effect of $\mathrm{p} / \mathrm{m}$ is small, the interaction effect of $\mathrm{p} / \mathrm{m}$ with estimation method is very strong.

The performance of $d$ from $\mathrm{ML}$ solutions was almost the reverse of the performance of $d$ from GLS solutions (see Figure 8). Almost all the values were positive. When sample size was 50 and 100 , the interaction effect of $\mathrm{N}$ and $\mathrm{p} / \mathrm{m}$ was strong. With an increased $\mathrm{p} / \mathrm{m}$ ratio, $d$ increased, which represents a departure from the null distribution. This departure is quite large when $\mathrm{p} / \mathrm{m}$ was 5 or $6 . d$ goes to an extreme value under the condition of $\mathrm{N}=50, \mathrm{~L}=.5$ and $\mathrm{p} / \mathrm{m}=3$. However, when sample size reached 200 , these departures almost disappeared. The loading size appeared to have no effect on $d$ with ML. Compared to the GLS solutions, we can see that the negative bias of $d$ with GLS was reversed with ML. The latter makes sense, while the former does not. However, with a sample size of 200 , the solutions were quite similar and they merged completely when $\mathrm{N}=500$. 
Table 9

Means and standard deviations for the Noncentrality $p$ it Index $d$

\begin{tabular}{|c|c|c|c|c|c|c|c|c|}
\hline & \multirow[b]{2}{*}{$\begin{array}{l}\text { Sample } \\
\text { Size }\end{array}$} & \multirow[b]{2}{*}{$\begin{array}{l}\mathrm{p} / \mathrm{m} \\
\text { ratio }\end{array}$} & \multicolumn{3}{|c|}{ GLS } & \multicolumn{3}{|c|}{ ML } \\
\hline & & & Hean & $\begin{array}{l}\text { Standard } \\
\text { Deviation }\end{array}$ & $\begin{array}{l}\text { Number } \\
\text { cases }\end{array}$ & Mean & $\begin{array}{l}\text { Standard } \\
\text { Deviation }\end{array}$ & $\begin{array}{l}\text { Number } \\
\text { cases }\end{array}$ \\
\hline \multirow{4}{*}{$\begin{array}{l}\text { Loading } \\
=0.50\end{array}$} & 50 & $\begin{array}{l}2 \\
3 \\
4 \\
5 \\
6\end{array}$ & $\begin{array}{r}0.0057 \\
0.0441 \\
-0.1073 \\
-0.1154 \\
-0.3427\end{array}$ & $\begin{array}{l}0.0669 \\
0.1839 \\
0.1858 \\
0.2768 \\
0.2616\end{array}$ & $\begin{array}{l}93 \\
69 \\
90 \\
37 \\
78\end{array}$ & $\begin{array}{l}0.0352 \\
0.8878 \\
0.1538 \\
0.2841 \\
0.5375\end{array}$ & $\begin{array}{l}0.0927 \\
2.8779 \\
0.2498 \\
0.3023 \\
0.3638\end{array}$ & $\begin{array}{l}97 \\
58 \\
95 \\
27 \\
99\end{array}$ \\
\hline & 100 & $\begin{array}{l}2 \\
3 \\
4 \\
5 \\
6\end{array}$ & $\begin{array}{l}-0.0059 \\
-0.0223 \\
-0.0223 \\
-0.0530 \\
-0.0470\end{array}$ & $\begin{array}{l}0.0268 \\
0.0573 \\
0.0967 \\
0.1379 \\
0.1493\end{array}$ & $\begin{array}{r}97 \\
100 \\
99 \\
98 \\
97\end{array}$ & $\begin{array}{r}-0.0008 \\
0.0009 \\
0.0394 \\
0.0613 \\
0.1451\end{array}$ & $\begin{array}{l}0.0310 \\
0.0716 \\
0.1098 \\
0.1577 \\
0.1789\end{array}$ & $\begin{array}{r}99 \\
99 \\
100 \\
100 \\
100\end{array}$ \\
\hline & 200 & $\begin{array}{l}2 \\
3 \\
4 \\
5 \\
6\end{array}$ & $\begin{array}{r}0.0000 \\
-0.0066 \\
-0.0067 \\
-0.0072 \\
-0.0164\end{array}$ & $\begin{array}{l}0.0187 \\
0.0339 \\
0.0419 \\
0.0690 \\
0.0799\end{array}$ & $\begin{array}{r}100 \\
99 \\
100 \\
100 \\
100\end{array}$ & $\begin{array}{r}0.0020 \\
-0.0005 \\
0.0096 \\
0.0212 \\
0.0296\end{array}$ & $\begin{array}{l}0.0207 \\
0.0367 \\
0.0436 \\
0.0735 \\
0.0944\end{array}$ & $\begin{array}{l}100 \\
100 \\
100 \\
100 \\
100\end{array}$ \\
\hline & 500 & $\begin{array}{l}2 \\
3 \\
4 \\
5 \\
5\end{array}$ & $\begin{array}{l}-0.0015 \\
-0.0009 \\
-0.0009 \\
-0.0033 \\
-0.0040\end{array}$ & $\begin{array}{l}0.0086 \\
0.0135 \\
0.0174 \\
0.0271 \\
0.0343\end{array}$ & $\begin{array}{l}100 \\
100 \\
100 \\
100 \\
100\end{array}$ & $\begin{array}{r}-0.0015 \\
0.0000 \\
0.0017 \\
0.0017 \\
0.0024\end{array}$ & $\begin{array}{l}0.0086 \\
0.0132 \\
0.0175 \\
0.0289 \\
0.0349\end{array}$ & $\begin{array}{l}100 \\
100 \\
100 \\
100 \\
100\end{array}$ \\
\hline \multirow{4}{*}{$\begin{array}{l}\text { Loading } \\
=0.70\end{array}$} & 50 & $\begin{array}{l}2 \\
3 \\
4 \\
5 \\
6\end{array}$ & $\begin{array}{l}-0.0109 \\
-0.0510 \\
-0.0793 \\
-0.1601 \\
-0.3070\end{array}$ & $\begin{array}{l}0.0592 \\
0.1197 \\
0.1950 \\
0.2329 \\
0.2594\end{array}$ & $\begin{array}{r}100 \\
100 \\
99 \\
98 \\
94\end{array}$ & $\begin{array}{l}0.0127 \\
0.0597 \\
0.1667 \\
0.3477 \\
0.5508\end{array}$ & $\begin{array}{l}0.0797 \\
0.1602 \\
0.2550 \\
0.2865 \\
0.3667\end{array}$ & $\begin{array}{l}100 \\
100 \\
100 \\
100 \\
100\end{array}$ \\
\hline & 100 & $\begin{array}{l}2 \\
3 \\
4 \\
5 \\
6\end{array}$ & $\begin{array}{l}-0.0040 \\
-0.0213 \\
-0.0173 \\
-0.0448 \\
-0.0425\end{array}$ & $\begin{array}{l}0.0339 \\
0.0561 \\
0.0984 \\
0.1415 \\
0.1474\end{array}$ & $\begin{array}{l}100 \\
100 \\
100 \\
100 \\
100\end{array}$ & $\begin{array}{l}0.0004 \\
0.0045 \\
0.0429 \\
0.0691 \\
0.1511\end{array}$ & $\begin{array}{l}0.0371 \\
0.0713 \\
0.1109 \\
0.1571 \\
0.1778\end{array}$ & $\begin{array}{l}100 \\
100 \\
100 \\
100 \\
100\end{array}$ \\
\hline & 200 & $\begin{array}{l}2 \\
3 \\
4 \\
5 \\
6\end{array}$ & $\begin{array}{l}-0.0022 \\
-0.0045 \\
-0.0067 \\
-0.0050 \\
-0.0142\end{array}$ & $\begin{array}{l}0.0174 \\
0.0337 \\
0.0423 \\
0.0700 \\
0.0820\end{array}$ & $\begin{array}{l}100 \\
100 \\
100 \\
100 \\
100\end{array}$ & $\begin{array}{r}-0.0009 \\
0.0003 \\
0.0102 \\
0.0232 \\
0.0316\end{array}$ & $\begin{array}{l}0.0186 \\
0.0368 \\
0.0432 \\
0.0733 \\
0.0945\end{array}$ & $\begin{array}{l}100 \\
100 \\
100 \\
100 \\
100\end{array}$ \\
\hline & 500 & $\begin{array}{l}2 \\
3 \\
4 \\
5 \\
6\end{array}$ & $\begin{array}{l}-0.0016 \\
-0.0010 \\
-0.0009 \\
=0.0034 \\
-0.0043\end{array}$ & $\begin{array}{l}0.0084 \\
0.0130 \\
0.0184 \\
0.0271 \\
0.0341\end{array}$ & $\begin{array}{l}100 \\
100 \\
100 \\
100 \\
100\end{array}$ & $\begin{array}{r}-0.0011 \\
0.0002 \\
0.0019 \\
0.0014 \\
0.0018\end{array}$ & $\begin{array}{l}0.0086 \\
0.0135 \\
0.0179 \\
0.0290 \\
0.0347\end{array}$ & $\begin{array}{l}100 \\
100 \\
100 \\
100 \\
100\end{array}$ \\
\hline \multirow{4}{*}{$\begin{array}{l}\text { Loading } \\
=0.90\end{array}$} & 50 & $\begin{array}{l}2 \\
3 \\
4 \\
5 \\
6\end{array}$ & $\begin{array}{r}0.0040 \\
-0.0462 \\
-0.0666 \\
-0.1558 \\
-0.2877\end{array}$ & $\begin{array}{l}0.0680 \\
0.1168 \\
0.2059 \\
0.2318 \\
0.2704\end{array}$ & $\begin{array}{r}100 \\
100 \\
100 \\
98 \\
95\end{array}$ & $\begin{array}{l}0.0281 \\
0.0687 \\
0.1725 \\
0.3570 \\
0.5581\end{array}$ & $\begin{array}{l}0.0893 \\
0.1649 \\
0.2631 \\
0.2876 \\
0.3688\end{array}$ & $\begin{aligned} 99 \\
100 \\
100 \\
100 \\
100\end{aligned}$ \\
\hline & 100 & $\begin{array}{l}2 \\
3 \\
4 \\
5 \\
6\end{array}$ & $\begin{array}{l}-0.0043 \\
-0.0208 \\
-0.0165 \\
-0.0458 \\
-0.0464\end{array}$ & $\begin{array}{l}0.0350 \\
0.0534 \\
0.1014 \\
0.1427 \\
0.1437\end{array}$ & $\begin{array}{l}100 \\
100 \\
100 \\
100 \\
100\end{array}$ & $\begin{array}{l}0.0005 \\
0.0069 \\
0.0424 \\
0.0702 \\
0.1559\end{array}$ & $\begin{array}{l}0.0388 \\
0.0719 \\
0.1120 \\
0.1586 \\
0.1770\end{array}$ & $\begin{array}{l}100 \\
100 \\
100 \\
100 \\
100\end{array}$ \\
\hline & 200 & $\begin{array}{l}2 \\
3 \\
4 \\
5 \\
6\end{array}$ & $\begin{array}{l}-0.0019 \\
-0.0055 \\
-0.0062 \\
-0.0016 \\
-0.0135\end{array}$ & $\begin{array}{l}0.0157 \\
0.0333 \\
0.0437 \\
0.0696 \\
0.0828\end{array}$ & $\begin{array}{l}100 \\
100 \\
100 \\
100 \\
100\end{array}$ & $\begin{array}{r}0.0011 \\
0.0002 \\
0.0103 \\
0.0265 \\
0.0333\end{array}$ & $\begin{array}{l}0.0168 \\
0.0372 \\
0.0427 \\
0.0721 \\
0.0946\end{array}$ & $\begin{array}{l}100 \\
100 \\
100 \\
100 \\
100\end{array}$ \\
\hline & 500 & $\begin{array}{l}2 \\
3 \\
4 \\
5 \\
6\end{array}$ & $\begin{array}{r}0.0003 \\
-0.0007 \\
-0.0007 \\
-0.0036 \\
-0.0034\end{array}$ & $\begin{array}{l}0.0085 \\
0.0134 \\
0.0182 \\
0.0266 \\
0.0351\end{array}$ & $\begin{array}{l}100 \\
100 \\
100 \\
100 \\
100\end{array}$ & $\begin{array}{r}0.0004 \\
-0.0005 \\
0.0015 \\
0.0015 \\
0.0021\end{array}$ & $\begin{array}{l}0.0084 \\
0.0135 \\
0.0175 \\
0.0274 \\
0.0356\end{array}$ & $\begin{array}{l}100 \\
100 \\
100 \\
100 \\
100\end{array}$ \\
\hline
\end{tabular}




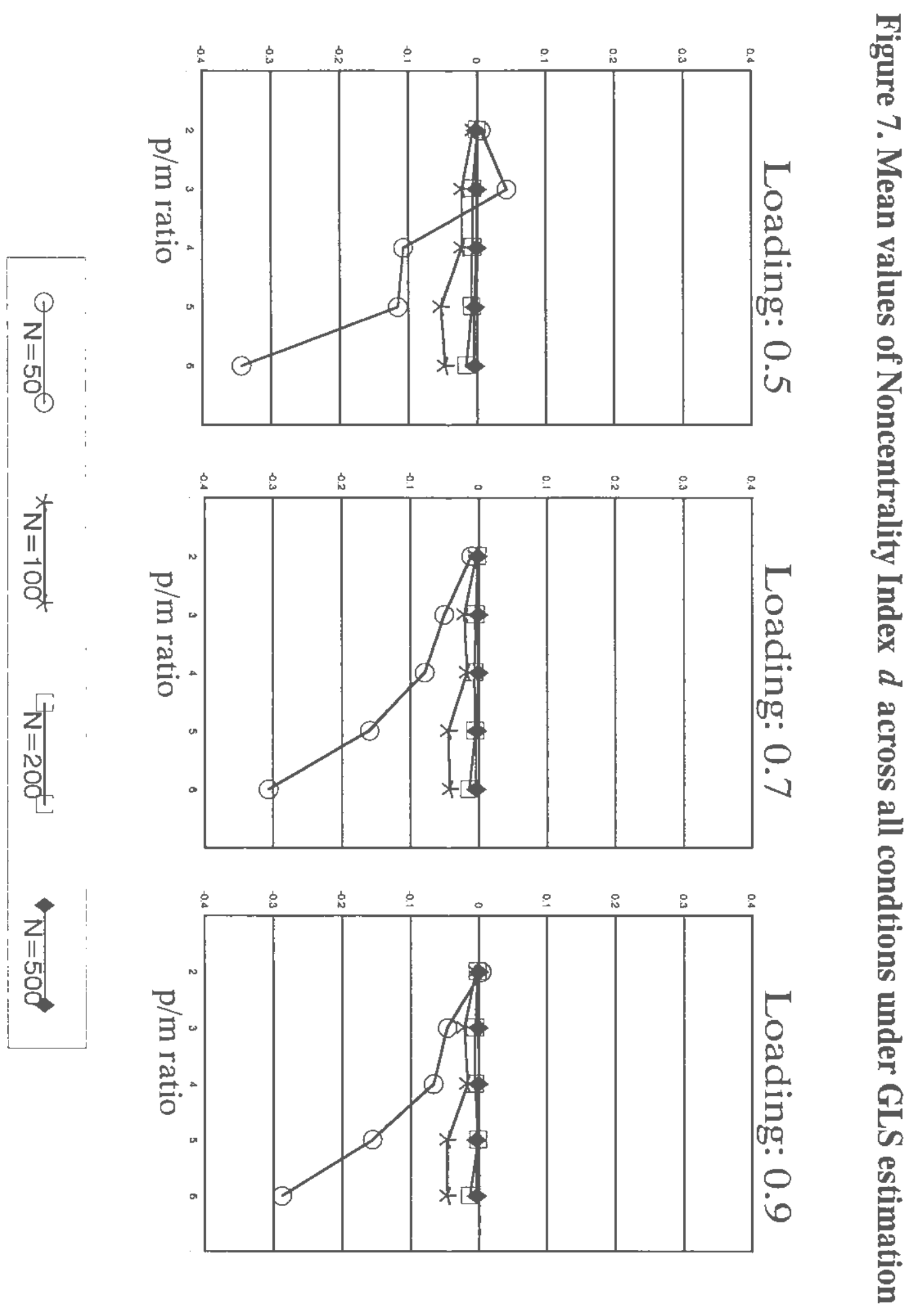




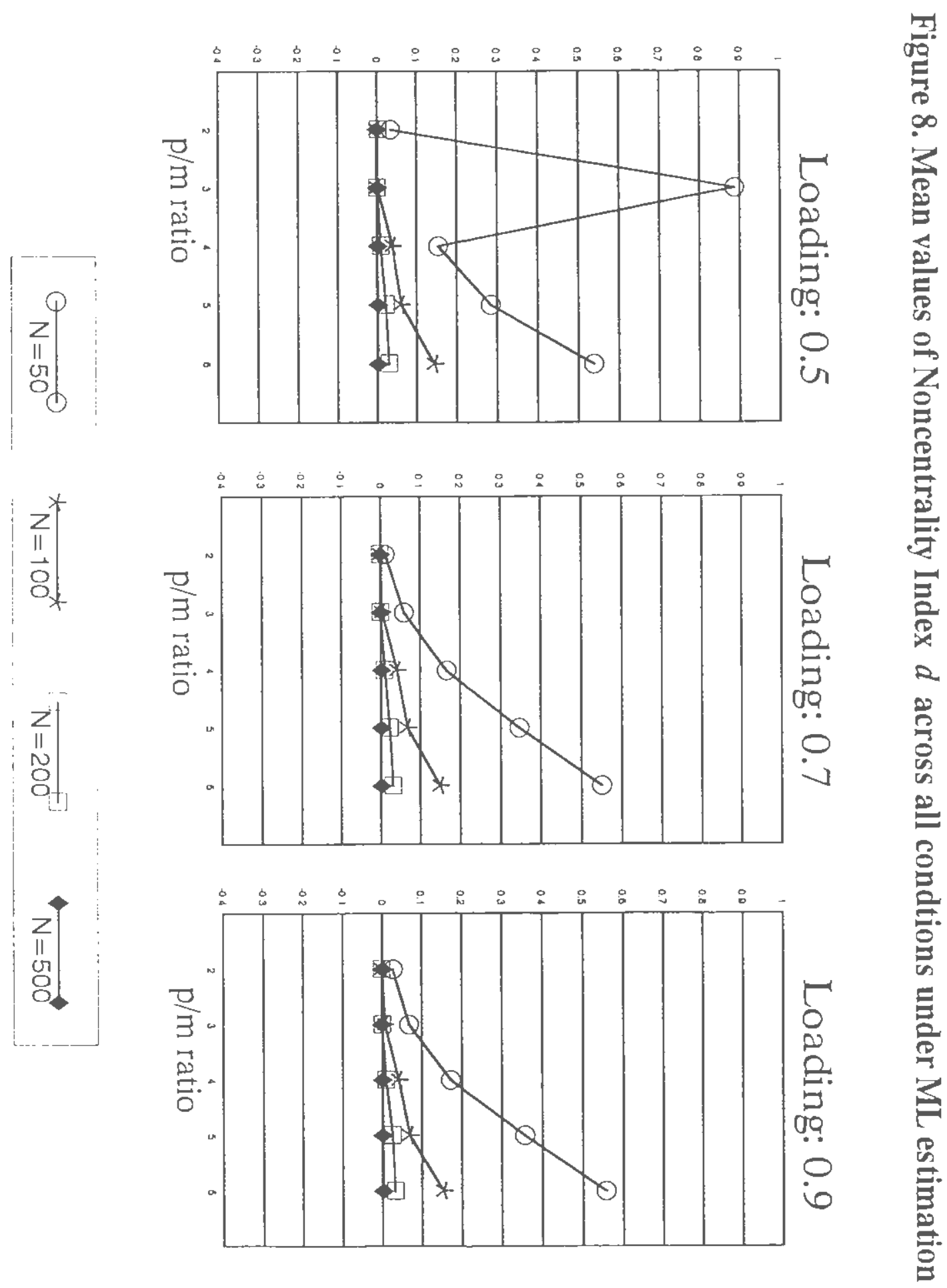




\section{Centrality $m$}

The Means and Standard Deviations are summarized in table 10 for estimates of $m$. The results are also illustrated in Figure 9 (GLS results) and Figure 10 (ML results). The MANOVA results for $m$ is summarized on Appendix A, Table A-4.

Magnitude of effects. The main effect of estimation method is $F_{(1,5747)}=1031.42$, $\eta^{2}=0.05$. The interaction effect between estimation method and sample size is $F_{(3.24)}$ $=495.72, \eta^{2}=0.07$. All other main and interaction effects were significant but their $\eta^{2}$ values were less than 0.05

The centrality index $m$ is the $\log$ transformation of $d$. This transformation narrowed the range of the value. Also note that a negative value of $d$ will result in an $m$ value that exceeds 1 . A value of 0 for $d$ is equal to an $m$ value of 1 , which reflects a perfect fit. Since the pattern of performance of this index is similar to that for noncentrality $d$, it is not necessary to describe the results in detail. 
Table 10

Means and standard deviations for Centrality Fit Index $m$

\begin{tabular}{|c|c|c|c|c|c|c|c|c|}
\hline & \multirow[b]{2}{*}{$\begin{array}{l}\text { Sample } \\
\text { Size }\end{array}$} & \multirow[b]{2}{*}{${ }_{\text {ratio }}$} & \multicolumn{3}{|c|}{ GLS } & \multicolumn{3}{|c|}{ ML } \\
\hline & & & Mean & $\begin{array}{l}\text { Standard } \\
\text { Deviation }\end{array}$ & $\begin{array}{l}\text { Number } \\
\text { cases }\end{array}$ & Hean & $\begin{array}{l}\text { Standard } \\
\text { Deviation }\end{array}$ & $\begin{array}{l}\text { Number } \\
\text { cases }\end{array}$ \\
\hline \multirow{4}{*}{$\begin{array}{l}\text { Loading } \\
=0.50\end{array}$} & 50 & $\begin{array}{l}2 \\
3 \\
4 \\
5 \\
5\end{array}$ & $\begin{array}{l}0.9977 \\
0.9819 \\
1.0591 \\
1.0705 \\
1.1972\end{array}$ & $\begin{array}{l}0.0332 \\
0.0882 \\
0.0962 \\
0.1519 \\
0.1536\end{array}$ & $\begin{array}{l}93 \\
69 \\
90 \\
37 \\
78\end{array}$ & $\begin{array}{l}0.9836 \\
0.8374 \\
0.9328 \\
0.8767 \\
0.7765\end{array}$ & $\begin{array}{l}0.0448 \\
0.2722 \\
0.1129 \\
0.1373 \\
0.1378\end{array}$ & $\begin{array}{l}97 \\
58 \\
95 \\
27 \\
99\end{array}$ \\
\hline & 100 & $\begin{array}{l}2 \\
3 \\
4 \\
5 \\
6\end{array}$ & $\begin{array}{l}1.0026 \\
1.0120 \\
1.0118 \\
1.0299 \\
1.0272\end{array}$ & $\begin{array}{l}0.0133 \\
0.0293 \\
0.0489 \\
0.0697 \\
0.0758\end{array}$ & $\begin{array}{r}97 \\
100 \\
99 \\
98 \\
97\end{array}$ & $\begin{array}{l}1.0004 \\
1.0003 \\
0.9816 \\
0.9730 \\
0.9339\end{array}$ & $\begin{array}{l}0.0154 \\
0.0357 \\
0.0534 \\
0.0753 \\
0.0827\end{array}$ & $\begin{array}{r}99 \\
99 \\
100 \\
100 \\
100\end{array}$ \\
\hline & 200 & $\begin{array}{l}2 \\
3 \\
4 \\
5 \\
6\end{array}$ & $\begin{array}{l}0.9996 \\
1.0034 \\
1.0043 \\
1.0040 \\
1.0082\end{array}$ & $\begin{array}{l}0.0101 \\
0.0172 \\
0.0210 \\
0.0348 \\
0.0409\end{array}$ & $\begin{array}{r}100 \\
99 \\
100 \\
100 \\
100\end{array}$ & $\begin{array}{l}0.9989 \\
1.9004 \\
0.9955 \\
0.9898 \\
0.9865\end{array}$ & $\begin{array}{l}0.0107 \\
0.0181 \\
0.0215 \\
0.0360 \\
0.0471\end{array}$ & $\begin{array}{l}100 \\
100 \\
100 \\
100 \\
100\end{array}$ \\
\hline & 500 & $\begin{array}{l}2 \\
3 \\
4 \\
5 \\
6\end{array}$ & $\begin{array}{l}0.9996 \\
1.0003 \\
1.0003 \\
1.0020 \\
1.0024\end{array}$ & $\begin{array}{l}0.0035 \\
0.0069 \\
0.0096 \\
0.0141 \\
0.0176\end{array}$ & $\begin{array}{l}100 \\
100 \\
100 \\
100 \\
100\end{array}$ & $\begin{array}{l}0.9994 \\
0.9999 \\
0.9995 \\
0.9992 \\
0.9991\end{array}$ & $\begin{array}{l}0.0037 \\
0.0072 \\
0.0090 \\
0.0147 \\
0.0176\end{array}$ & $\begin{array}{l}100 \\
100 \\
100 \\
100 \\
100\end{array}$ \\
\hline \multirow{4}{*}{$\begin{array}{l}\text { Loading } \\
=0.70\end{array}$} & 50 & $\begin{array}{l}2 \\
3 \\
4 \\
5 \\
6\end{array}$ & $\begin{array}{l}1.0053 \\
1.0269 \\
1.0455 \\
1.0897 \\
1.1759\end{array}$ & $\begin{array}{l}0.0290 \\
0.0584 \\
0.0999 \\
0.1260 \\
0.1513\end{array}$ & $\begin{array}{r}100 \\
100 \\
99 \\
98 \\
94\end{array}$ & $\begin{array}{l}0.9948 \\
0.9733 \\
0.9269 \\
0.8487 \\
0.7715\end{array}$ & $\begin{array}{l}0.0386 \\
0.0748 \\
0.1141 \\
0.1240 \\
0.1397\end{array}$ & $\begin{array}{l}100 \\
100 \\
100 \\
100 \\
100\end{array}$ \\
\hline & 100 & $\begin{array}{l}2 \\
3 \\
4 \\
5 \\
6\end{array}$ & $\begin{array}{l}1.0023 \\
1.0109 \\
1.0097 \\
1.0252 \\
1.0244\end{array}$ & $\begin{array}{l}0.0170 \\
0.0282 \\
0.0497 \\
0.0706 \\
0.0756\end{array}$ & $\begin{array}{l}100 \\
100 \\
100 \\
100 \\
100\end{array}$ & $\begin{array}{l}1.0002 \\
0.9985 \\
0.9804 \\
0.9688 \\
0.9307\end{array}$ & $\begin{array}{l}0.0191 \\
0.0348 \\
0.0541 \\
0.0755 \\
0.0824\end{array}$ & $\begin{array}{l}100 \\
100 \\
100 \\
100 \\
100\end{array}$ \\
\hline & 200 & $\begin{array}{l}2 \\
3 \\
4 \\
5 \\
6\end{array}$ & $\begin{array}{l}1.0013 \\
1.0025 \\
1.0033 \\
1.0028 \\
1.0077\end{array}$ & $\begin{array}{l}0.0090 \\
0.0171 \\
0.0216 \\
0.0349 \\
0.0418\end{array}$ & $\begin{array}{l}100 \\
100 \\
100 \\
100 \\
100\end{array}$ & $\begin{array}{l}1.0008 \\
0.9998 \\
0.9950 \\
0.9895 \\
0.9855\end{array}$ & $\begin{array}{l}0.0094 \\
0.0179 \\
0.0208 \\
0.0359 \\
0.0465\end{array}$ & $\begin{array}{l}100 \\
100 \\
100 \\
100 \\
100\end{array}$ \\
\hline & 500 & $\begin{array}{l}2 \\
3 \\
4 \\
5 \\
6\end{array}$ & $\begin{array}{l}1.0003 \\
1.0003 \\
1.0002 \\
1.0020 \\
1.0022\end{array}$ & $\begin{array}{l}0.0039 \\
0.0067 \\
0.0095 \\
0.0136 \\
0.0177\end{array}$ & $\begin{array}{l}100 \\
100 \\
100 \\
100 \\
100\end{array}$ & $\begin{array}{l}1.0003 \\
0.9997 \\
0.9994 \\
0.9989 \\
0.9995\end{array}$ & $\begin{array}{l}0.0039 \\
0.0069 \\
0.0093 \\
0.0141 \\
0.0178\end{array}$ & $\begin{array}{l}100 \\
100 \\
100 \\
100 \\
100\end{array}$ \\
\hline \multirow{4}{*}{$\begin{array}{l}\text { Loading } \\
=0.90\end{array}$} & 50 & $\begin{array}{l}2 \\
3 \\
4 \\
5 \\
6\end{array}$ & $\begin{array}{l}0.9989 \\
1.0253 \\
1.0390 \\
1.0881 \\
1.1648\end{array}$ & $\begin{array}{l}0.0341 \\
0.0581 \\
0.1036 \\
0.1258 \\
0.1543\end{array}$ & $\begin{array}{r}100 \\
100 \\
100 \\
98 \\
95\end{array}$ & $\begin{array}{l}0.9867 \\
0.9697 \\
0.9252 \\
0.8455 \\
0.7701\end{array}$ & $\begin{array}{l}0.0432 \\
0.0770 \\
0.1177 \\
0.1237 \\
0.1411\end{array}$ & $\begin{array}{r}99 \\
100 \\
100 \\
100 \\
100\end{array}$ \\
\hline & 100 & $\begin{array}{l}2 \\
3 \\
4 \\
5 \\
6\end{array}$ & $\begin{array}{l}1.0018 \\
1.0102 \\
1.0094 \\
1.0258 \\
1.0260\end{array}$ & $\begin{array}{l}0.0182 \\
0.0276 \\
0.0508 \\
0.0716 \\
0.0737\end{array}$ & $\begin{array}{l}100 \\
100 \\
100 \\
100 \\
100\end{array}$ & $\begin{array}{l}1.0003 \\
0.9971 \\
0.9806 \\
0.9683 \\
0.9289\end{array}$ & $\begin{array}{l}0.0195 \\
0.0364 \\
0.0545 \\
0.0764 \\
0.0821\end{array}$ & $\begin{array}{l}100 \\
100 \\
100 \\
100 \\
100\end{array}$ \\
\hline & 200 & $\begin{array}{l}2 \\
3 \\
4 \\
5 \\
6\end{array}$ & $\begin{array}{l}1.0012 \\
1.0029 \\
1.0031 \\
1.0014 \\
1.0076\end{array}$ & $\begin{array}{l}0.0081 \\
0.0162 \\
0.0222 \\
0.0342 \\
0.0419\end{array}$ & $\begin{array}{l}100 \\
100 \\
100 \\
100 \\
100\end{array}$ & $\begin{array}{l}1.0006 \\
0.9995 \\
0.9948 \\
0.9874 \\
0.9947\end{array}$ & $\begin{array}{l}0.0085 \\
0.0178 \\
0.0219 \\
0.0352 \\
0.0470\end{array}$ & $\begin{array}{l}100 \\
100 \\
100 \\
100 \\
100\end{array}$ \\
\hline & 500 & $\begin{array}{l}2 \\
3 \\
4 \\
5 \\
6\end{array}$ & $\begin{array}{l}0.9992 \\
1.0004 \\
1.0005 \\
1.0016 \\
1.0021\end{array}$ & $\begin{array}{l}0.0037 \\
0.0070 \\
0.0097 \\
0.0132 \\
0.0181\end{array}$ & $\begin{array}{l}100 \\
100 \\
100 \\
100 \\
100\end{array}$ & $\begin{array}{l}0.9990 \\
1.0000 \\
0.9992 \\
0.9997 \\
0.9992\end{array}$ & $\begin{array}{l}0.0039 \\
0.0074 \\
0.0096 \\
0.0134 \\
0.0172\end{array}$ & $\begin{array}{l}100 \\
100 \\
100 \\
100 \\
100\end{array}$ \\
\hline
\end{tabular}




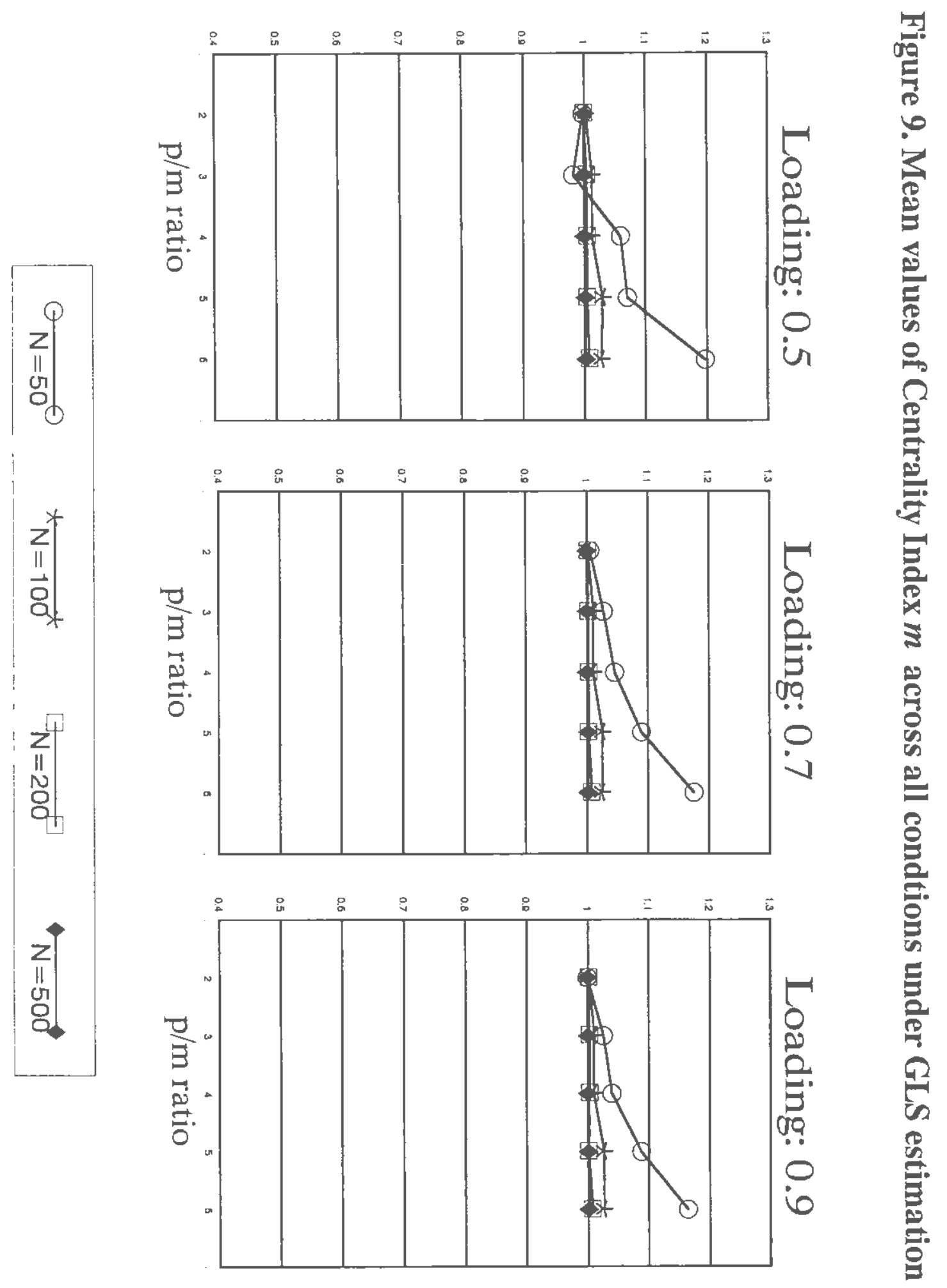




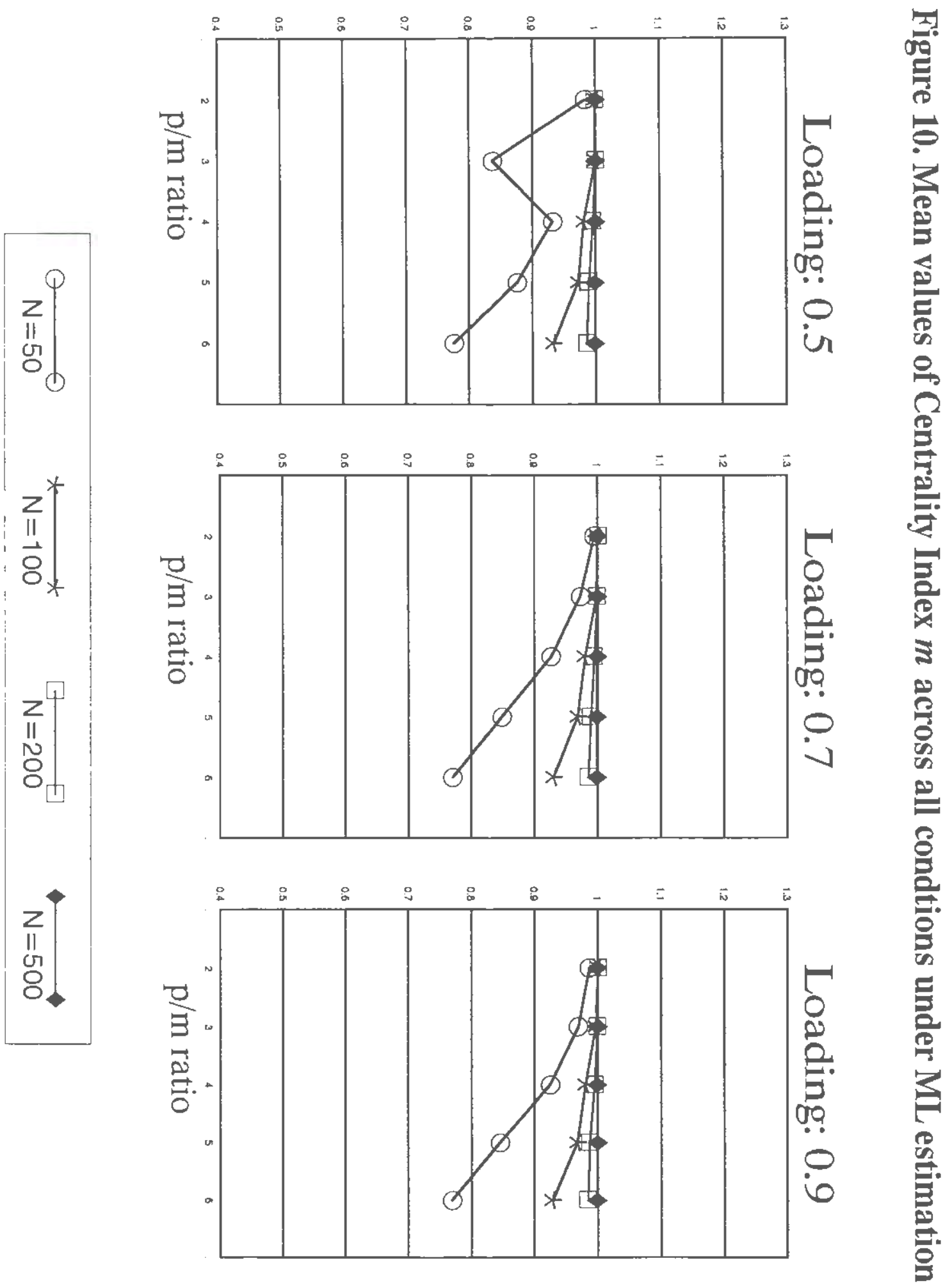




\section{Relative Noncentrality Index (RN)}

The Means and Standard Deviations are reported in Table 11 for RNI estimates. The results are also illustrated in Figure 11 (GLS results) and Figure 12 (ML results). The MANOVA results are summarized in Appendix A, Table A-5.

Magnitude of effects. The only significant effect for RNI is the main effect of estimation method, $\mathrm{F}_{(1,574)}=7.84, \mathrm{p}<.01$. However, the $\eta^{2}<0.01$. RNI appears to be relatively independent of $\mathrm{N}, \mathrm{L}$ and $\mathrm{p} / \mathrm{m}$.

Variability. The SDs from GLS are ranged from 0.0000 to 0.0169 across all conditions for GLS, and from 0.0000 to 0.5010 for ML (excluding the condition $\mathrm{N}=50$, $\mathrm{L}=.5$ and $\mathrm{p} / \mathrm{m}=3$, where $\mathrm{SD}=3.3389$ ). The variability of $\mathrm{RNI}$ is decreased when $\mathrm{N}$ increased, L increased, and $\mathrm{p} / \mathrm{m}$ increased. Compared to NNFI and NFI, RNI had the smallest variability.

Pattern of Performance. Solutions from GLS appear almost perfect. However, RNI from ML showed some downward bias when sample size was 50 . Once $\mathrm{N}$ reached 100 , all factors examined here do not appear to have serious effects on RNI. 
Table 11

Means and standard Deviations for the Relative Noncentrality Index

\begin{tabular}{|c|c|c|c|c|c|c|c|c|}
\hline & \multirow[b]{2}{*}{$\begin{array}{c}\text { Sample } \\
\text { Size }\end{array}$} & \multirow[b]{2}{*}{$\begin{array}{l}\mathrm{p} / \mathrm{m} \\
\mathrm{ratio}\end{array}$} & \multicolumn{3}{|c|}{ GISS } & \multicolumn{3}{|c|}{ MI } \\
\hline & & & Mean & $\begin{array}{l}\text { Standard } \\
\text { Deviation }\end{array}$ & $\begin{array}{l}\text { Number } \\
\text { cases }\end{array}$ & Mean & $\begin{array}{l}\text { Standard } \\
\text { Deviation }\end{array}$ & $\begin{array}{l}\text { Number } \\
\text { cases }\end{array}$ \\
\hline \multirow{4}{*}{$\begin{array}{l}\text { Loading } \\
=0.50\end{array}$} & 50 & $\begin{array}{l}2 \\
3 \\
4 \\
5 \\
6\end{array}$ & $\begin{array}{l}1.0002 \\
0.9965 \\
1.0070 \\
1.0049 \\
1.0076\end{array}$ & $\begin{array}{l}0.0118 \\
0.0169 \\
0.0105 \\
0.0104 \\
0.0069\end{array}$ & $\begin{array}{l}93 \\
69 \\
90 \\
37 \\
78\end{array}$ & $\begin{array}{l}0.9021 \\
1.1360 \\
0.9241 \\
0.8789 \\
0.8295\end{array}$ & $\begin{array}{l}0.5010 \\
3.3389 \\
0.2046 \\
0.1508 \\
0.1139\end{array}$ & $\begin{array}{l}97 \\
58 \\
95 \\
27 \\
99\end{array}$ \\
\hline & 100 & $\begin{array}{l}2 \\
3 \\
4 \\
5 \\
6\end{array}$ & $\begin{array}{l}1.0010 \\
1.0031 \\
1.0029 \\
1.0037 \\
1.0024\end{array}$ & $\begin{array}{l}0.0064 \\
0.0075 \\
0.0074 \\
0.0083 \\
0.0067\end{array}$ & $\begin{array}{r}97 \\
100 \\
99 \\
98 \\
97\end{array}$ & $\begin{array}{l}1.0046 \\
1.0093 \\
0.9773 \\
0.9717 \\
0.9467\end{array}$ & $\begin{array}{l}0.1027 \\
0.0974 \\
0.0809 \\
0.0052 \\
0.0711\end{array}$ & $\begin{array}{r}99 \\
99 \\
100 \\
100 \\
100\end{array}$ \\
\hline & 200 & $\begin{array}{l}2 \\
3 \\
4 \\
5 \\
6\end{array}$ & $\begin{array}{l}0.9996 \\
1.0007 \\
1.0004 \\
1.0006 \\
1.0011\end{array}$ & $\begin{array}{l}0.0042 \\
0.0052 \\
0.0049 \\
0.0055 \\
0.0045\end{array}$ & $\begin{array}{r}100 \\
99 \\
100 \\
100 \\
100\end{array}$ & $\begin{array}{l}1.0002 \\
1.0027 \\
0.9941 \\
0.9889 \\
0.9889\end{array}$ & $\begin{array}{l}0.0506 \\
0.0458 \\
0.0322 \\
0.0399 \\
0.0363\end{array}$ & $\begin{array}{l}100 \\
100 \\
100 \\
100 \\
100\end{array}$ \\
\hline & 500 & $\begin{array}{l}2 \\
3 \\
4 \\
5 \\
6\end{array}$ & $\begin{array}{l}0.9999 \\
1.0000 \\
1.0000 \\
0.9999 \\
1.0000\end{array}$ & $\begin{array}{l}0.0010 \\
0.0000 \\
0.0000 \\
0.0010 \\
0.0000\end{array}$ & $\begin{array}{l}100 \\
100 \\
100 \\
100 \\
100\end{array}$ & $\begin{array}{l}1.0024 \\
1.0005 \\
0.9987 \\
0.9995 \\
0.9988\end{array}$ & $\begin{array}{l}0.0192 \\
0.0159 \\
0.0132 \\
0.0160 \\
0.0139\end{array}$ & $\begin{array}{l}100 \\
100 \\
100 \\
100 \\
100\end{array}$ \\
\hline \multirow{4}{*}{$\begin{array}{l}\text { Loading } \\
=0.70\end{array}$} & 50 & $\begin{array}{l}2 \\
3 \\
4 \\
5 \\
6\end{array}$ & $\begin{array}{l}1.0019 \\
1.0031 \\
1.0028 \\
1.0024 \\
1.0022\end{array}$ & $\begin{array}{l}0.0065 \\
0.0060 \\
0.0055 \\
0.0046 \\
0.0042\end{array}$ & $\begin{array}{r}100 \\
100 \\
99 \\
98 \\
94\end{array}$ & $\begin{array}{l}0.9960 \\
0.9786 \\
0.9625 \\
0.9415 \\
0.9288\end{array}$ & $\begin{array}{l}0.0702 \\
0.0609 \\
0.0642 \\
0.0492 \\
0.0493\end{array}$ & $\begin{array}{l}100 \\
100 \\
100 \\
100 \\
100\end{array}$ \\
\hline & 100 & $\begin{array}{l}2 \\
3 \\
4 \\
5 \\
6\end{array}$ & $\begin{array}{l}0.9995 \\
1.0012 \\
1.0010 \\
1.0010 \\
1.0006\end{array}$ & $\begin{array}{l}0.0039 \\
0.0043 \\
0.0041 \\
0.0046 \\
0.0028\end{array}$ & $\begin{array}{l}100 \\
100 \\
100 \\
100 \\
100\end{array}$ & $\begin{array}{l}1.0009 \\
0.9995 \\
0.9902 \\
0.9880 \\
0.9796\end{array}$ & $\begin{array}{l}0.0308 \\
0.0299 \\
0.0263 \\
0.0292 \\
0.0253\end{array}$ & $\begin{array}{l}100 \\
100 \\
100 \\
100 \\
100\end{array}$ \\
\hline & 200 & $\begin{array}{l}2 \\
3 \\
4 \\
5 \\
6\end{array}$ & $\begin{array}{l}0.9998 \\
1.0000 \\
1.0000 \\
1.0000 \\
1.0003\end{array}$ & $\begin{array}{l}0.0014 \\
0.0014 \\
0.0000 \\
0.0014 \\
0.0017\end{array}$ & $\begin{array}{l}100 \\
100 \\
100 \\
100 \\
100\end{array}$ & $\begin{array}{l}1.0014 \\
0.9997 \\
0.9973 \\
0.9955 \\
0.9956\end{array}$ & $\begin{array}{l}0.0168 \\
0.0148 \\
0.0112 \\
0.0142 \\
0.0127\end{array}$ & $\begin{array}{l}100 \\
100 \\
100 \\
100 \\
100\end{array}$ \\
\hline & 500 & $\begin{array}{l}2 \\
3 \\
4 \\
5 \\
6\end{array}$ & $\begin{array}{l}1.0000 \\
1.0000 \\
1.0000 \\
1.0000 \\
1.0000\end{array}$ & $\begin{array}{l}0.0000 \\
0.0000 \\
0.0000 \\
0.0000 \\
0.0000\end{array}$ & $\begin{array}{l}100 \\
100 \\
100 \\
100 \\
100\end{array}$ & $\begin{array}{l}1.0014 \\
1.0002 \\
0.9995 \\
0.9997 \\
1.0003\end{array}$ & $\begin{array}{l}0.0075 \\
0.0060 \\
0.0054 \\
0.0059 \\
0.0058\end{array}$ & $\begin{array}{l}100 \\
100 \\
100 \\
100 \\
100\end{array}$ \\
\hline \multirow{4}{*}{$\begin{array}{l}\text { Loading } \\
=0.90^{\circ}\end{array}$} & 50 & $\begin{array}{l}2 \\
3 \\
4 \\
5 \\
6\end{array}$ & $\begin{array}{l}1.0000 \\
1.0000 \\
1.0000 \\
1.0000 \\
1.0000\end{array}$ & $\begin{array}{l}0.0000 \\
0.0000 \\
0.0000 \\
0.0000 \\
0.0000\end{array}$ & $\begin{array}{r}100 \\
100 \\
100 \\
98 \\
95\end{array}$ & $\begin{array}{l}0.9923 \\
0.9916 \\
0.9864 \\
0.9785 \\
0.9745\end{array}$ & $\begin{array}{l}0.0232 \\
0.0210 \\
0.0220 \\
0.0174 \\
0.0180\end{array}$ & $\begin{array}{r}99 \\
100 \\
100 \\
100 \\
100\end{array}$ \\
\hline & 100 & $\begin{array}{l}2 \\
3 \\
4 \\
5 \\
6\end{array}$ & $\begin{array}{l}1.0000 \\
1.0000 \\
1.0000 \\
1.0000 \\
1.0000\end{array}$ & $\begin{array}{l}0.0000 \\
0.0000 \\
0.0000 \\
0.0000 \\
0.0000\end{array}$ & $\begin{array}{l}100 \\
100 \\
100 \\
100 \\
100\end{array}$ & $\begin{array}{l}1.0004 \\
0.9997 \\
0.9967 \\
0.9957 \\
0.9934\end{array}$ & $\begin{array}{l}0.0108 \\
0.0098 \\
0.0097 \\
0.0097 \\
0.0093\end{array}$ & $\begin{array}{l}100 \\
100 \\
100 \\
100 \\
100\end{array}$ \\
\hline & 200 & $\begin{array}{l}2 \\
3 \\
4 \\
5 \\
6\end{array}$ & $\begin{array}{l}1.0000 \\
1.0000 \\
1.0000 \\
1.0000 \\
1.0000\end{array}$ & $\begin{array}{l}0.0000 \\
0.0000 \\
0.0000 \\
0.0000 \\
0.0000\end{array}$ & $\begin{array}{l}100 \\
100 \\
100 \\
100 \\
100\end{array}$ & $\begin{array}{l}1.0004 \\
0.9997 \\
0.9991 \\
0.9983 \\
0.9990\end{array}$ & $\begin{array}{l}0.0053 \\
0.0056 \\
0.0040 \\
0.0055 \\
0.0052\end{array}$ & $\begin{array}{l}100 \\
100 \\
100 \\
100 \\
100\end{array}$ \\
\hline & 500 & $\begin{array}{l}2 \\
3 \\
4 \\
5 \\
6\end{array}$ & $\begin{array}{l}1.0000 \\
1.0000 \\
1.0000 \\
1.0000 \\
1.0000\end{array}$ & $\begin{array}{l}0.0000 \\
0.0000 \\
0.0000 \\
0.0000 \\
0.0000\end{array}$ & $\begin{array}{l}100 \\
100 \\
100 \\
100 \\
100\end{array}$ & $\begin{array}{l}0.9997 \\
1.0000 \\
1.0000 \\
1.0000 \\
1.0000\end{array}$ & $\begin{array}{l}0.0017 \\
0.0000 \\
0.0000 \\
0.0000 \\
0.0000\end{array}$ & $\begin{array}{l}100 \\
100 \\
100 \\
100 \\
100\end{array}$ \\
\hline
\end{tabular}




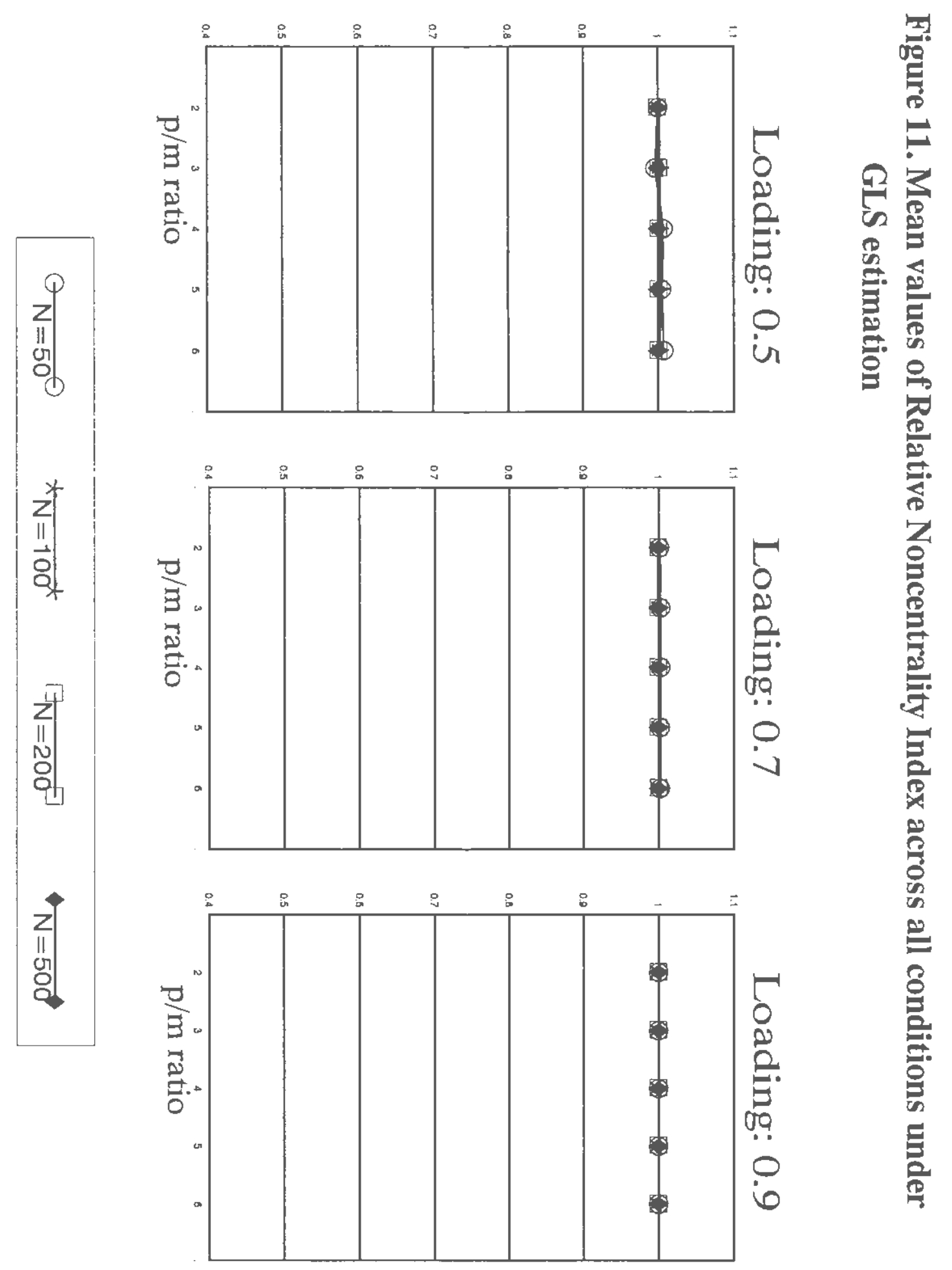


9
0
0
0
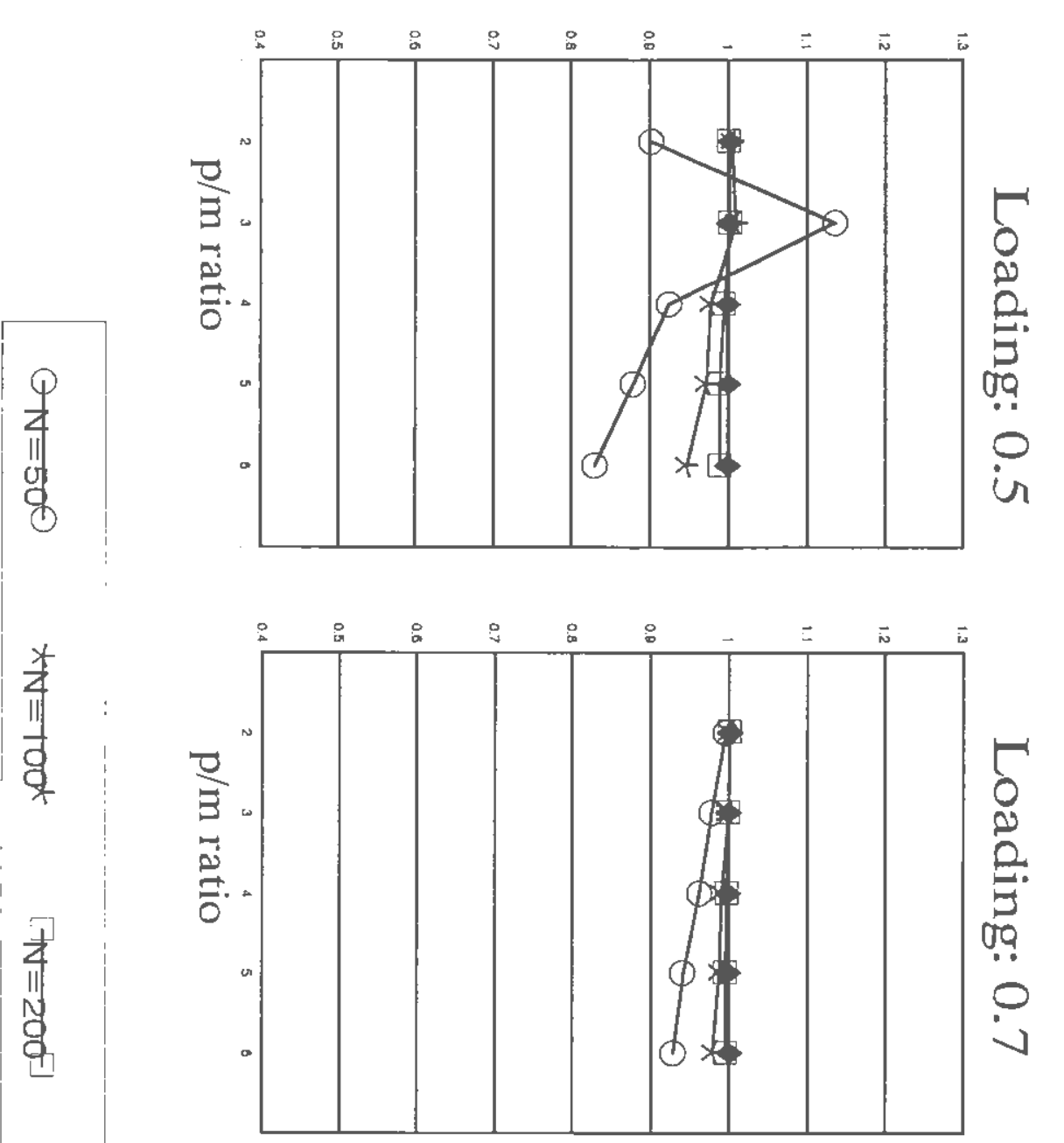

娄

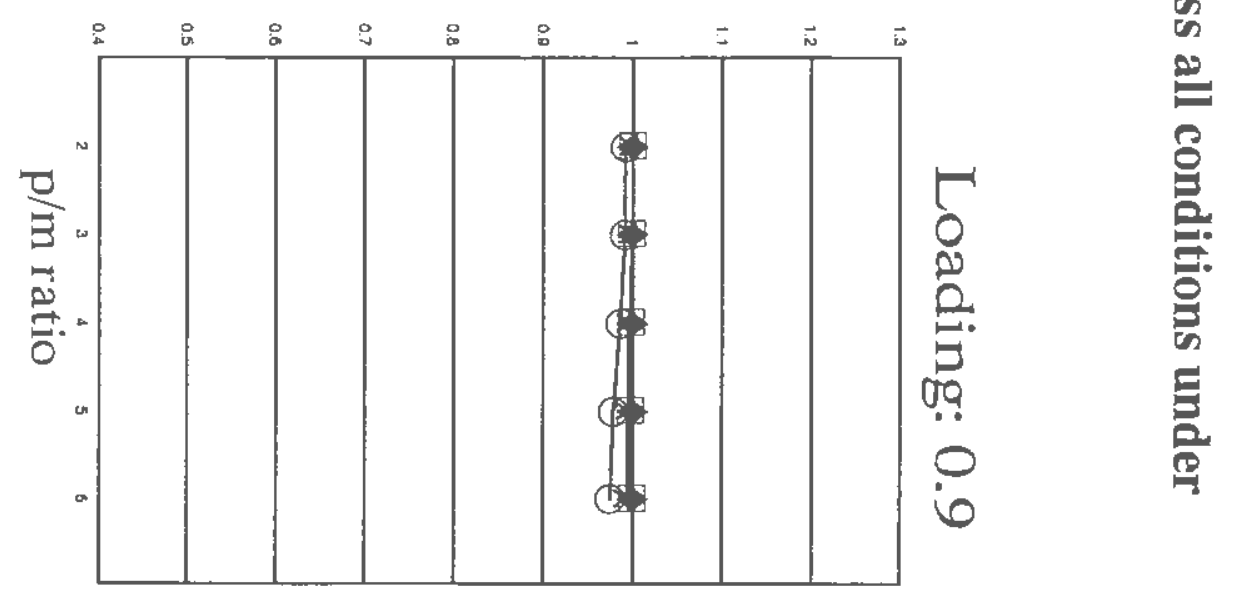




\section{Comparative Fit Index (CFD)}

The Means and Standard Deviations are reported in Table 12 for CFI estimates. The results are also illustrated in Figure 13 (GLS results) and Figure 14 (ML results). The MANOVA results are summarized in Appendix A, Table A-6.

Magnitude of effects. The main effect of sample size was $F_{(3,5746)}=457.59$, $\eta^{2}=0.07$. The main effect of estimation method was $F_{(1,5746)}=1446.43, \eta^{2}=0.06$. The interaction effect between estimation method and sample size was $F_{(3.24)}=484.58, \eta^{2}=$ 0.07. All other main effects and interaction effects were significant but did not reach the required $\eta^{2}$ level of .05 .

Variability. The Standard Deviations ranged from 0.0000 to 0.0119 across all conditions for GLS solutions and from 0.0000 to 0.1463 for ML solutions (except for the condition of $\mathrm{N}=50, \mathrm{~L}=.5, \mathrm{p} / \mathrm{m}=3$, which is 0.4067 ). SDs are decreased when $\mathrm{N}$ increased or $\mathrm{L}$ increased. The $\mathrm{p} / \mathrm{m}$ ratio had only a small influence on CFI. CFI had the smallest variability compare to all other indices in this study.

Pattern of performance. The effects of sample size and loading size are bigger on CFI than that on RNI. However, CFI performs similar to RNI in general given the fact that $\mathrm{CFI}=\mathrm{RN}$ when RNI $\leq 1$ (see Figure 13 and Figure 14). The magnitude of the bias of these two indices are very close. 
Table 12

Means and standard Deviations for the Comparative Fit Index

\begin{tabular}{|c|c|c|c|c|c|c|c|c|}
\hline & \multirow[b]{2}{*}{$\begin{array}{l}\text { Sample } \\
\text { Size }\end{array}$} & \multirow[b]{2}{*}{$\begin{array}{l}\mathrm{p} / \mathrm{m} \\
\text { Iatio }\end{array}$} & \multicolumn{3}{|c|}{ GLS } & \multicolumn{3}{|c|}{ MI } \\
\hline & & & Hean & $\begin{array}{l}\text { Standard } \\
\text { Deviation }\end{array}$ & $\begin{array}{l}\text { Number } \\
\text { cases }\end{array}$ & Mean & $\begin{array}{l}\text { Standard } \\
\text { Deviation }\end{array}$ & $\begin{array}{l}\text { Number } \\
\text { cases }\end{array}$ \\
\hline \multirow{4}{*}{$\begin{array}{l}\text { Loading } \\
=0.50\end{array}$} & 50 & $\begin{array}{l}2 \\
3 \\
4 \\
5 \\
6\end{array}$ & $\begin{array}{l}0.9958 \\
0.9914 \\
0.9987 \\
0.9986 \\
1.0000\end{array}$ & $\begin{array}{l}0.0077 \\
0.0119 \\
0.0034 \\
0.0035 \\
0.0000\end{array}$ & $\begin{array}{l}93 \\
69 \\
90 \\
37 \\
78\end{array}$ & $\begin{array}{l}0.8973 \\
0.6798 \\
0.9871 \\
0.8574 \\
0.8269\end{array}$ & $\begin{array}{l}0.1463 \\
0.4067 \\
0.1285 \\
0.1165 \\
0.1089\end{array}$ & $\begin{array}{l}96 \\
59 \\
95 \\
27 \\
99\end{array}$ \\
\hline & 100 & $\begin{array}{l}2 \\
3 \\
4 \\
5 \\
6\end{array}$ & $\begin{array}{l}0.9986 \\
0.9989 \\
0.9988 \\
0.9987 \\
0.9990\end{array}$ & $\begin{array}{l}0.0035 \\
0.0031 \\
0.0036 \\
0.0037 \\
0.0034\end{array}$ & $\begin{array}{r}97 \\
100 \\
99 \\
98 \\
97\end{array}$ & $\begin{array}{l}0.9661 \\
0.9676 \\
0.9545 \\
0.9512 \\
0.9376\end{array}$ & $\begin{array}{l}0.0629 \\
0.0524 \\
0.0543 \\
0.0593 \\
0.0575\end{array}$ & $\begin{array}{r}99 \\
99 \\
100 \\
100 \\
100\end{array}$ \\
\hline & 200 & $\begin{array}{l}2 \\
3 \\
4 \\
5 \\
6\end{array}$ & $\begin{array}{l}0.9989 \\
0.9990 \\
0.9990 \\
0.9989 \\
0.9995\end{array}$ & $\begin{array}{l}0.0031 \\
0.0030 \\
0.0030 \\
0.0035 \\
0.0022\end{array}$ & $\begin{array}{l}100 \\
99 \\
100 \\
100 \\
100\end{array}$ & $\begin{array}{l}0.9816 \\
0.9833 \\
0.9840 \\
0.9777 \\
0.9791\end{array}$ & $\begin{array}{l}0.0346 \\
0.0272 \\
0.0215 \\
0.0273 \\
0.0230\end{array}$ & $\begin{array}{l}100 \\
100 \\
100 \\
100 \\
100\end{array}$ \\
\hline & 500 & $\begin{array}{l}2 \\
3 \\
4 \\
5 \\
6\end{array}$ & $\begin{array}{l}0.9999 \\
1.0000 \\
1.0000 \\
0.9999 \\
1.0000\end{array}$ & $\begin{array}{l}0.0010 \\
0.0000 \\
0.0000 \\
0.0010 \\
0.0000\end{array}$ & $\begin{array}{l}100 \\
100 \\
100 \\
100 \\
100\end{array}$ & $\begin{array}{l}0.9937 \\
0.9940 \\
0.9942 \\
0.9935 \\
0.9940\end{array}$ & $\begin{array}{l}0.0128 \\
0.0086 \\
0.0087 \\
0.0095 \\
0.0089\end{array}$ & $\begin{array}{l}100 \\
100 \\
100 \\
100 \\
100\end{array}$ \\
\hline \multirow{4}{*}{$\begin{array}{l}\text { Loading } \\
=0.70\end{array}$} & 50 & $\begin{array}{l}2 \\
3 \\
4 \\
5 \\
6\end{array}$ & $\begin{array}{l}0.9988 \\
0.9994 \\
0.9996 \\
1.0000 \\
1.0000\end{array}$ & $\begin{array}{l}0.0033 \\
0.0024 \\
0.0020 \\
0.0000 \\
0.0000\end{array}$ & $\begin{array}{r}100 \\
100 \\
99 \\
98 \\
94\end{array}$ & $\begin{array}{l}0.9696 \\
0.9646 \\
0.9541 \\
0.9379 \\
0.9279\end{array}$ & $\begin{array}{l}0.0439 \\
0.0459 \\
0.0540 \\
0.0428 \\
0.0476\end{array}$ & $\begin{array}{l}100 \\
100 \\
100 \\
100 \\
100\end{array}$ \\
\hline & 100 & $\begin{array}{l}2 \\
3 \\
4 \\
5 \\
6\end{array}$ & $\begin{array}{l}0.9990 \\
0.9996 \\
0.9996 \\
0.9994 \\
0.9999\end{array}$ & $\begin{array}{l}0.0030 \\
0.0020 \\
0.0020 \\
0.0024 \\
0.0010\end{array}$ & $\begin{array}{l}100 \\
100 \\
100 \\
100 \\
100\end{array}$ & $\begin{array}{l}0.9884 \\
0.9891 \\
0.9831 \\
0.9820 \\
0.9770\end{array}$ & $\begin{array}{l}0.0208 \\
0.0189 \\
0.0206 \\
0.0221 \\
0.0215\end{array}$ & $\begin{array}{l}100 \\
100 \\
100 \\
100 \\
100\end{array}$ \\
\hline & 200 & $\begin{array}{l}2 \\
3 \\
4 \\
5 \\
6\end{array}$ & $\begin{array}{l}0.9999 \\
0.9999 \\
1.0000 \\
0.9999 \\
1.0000\end{array}$ & $\begin{array}{l}0.0014 \\
0.0010 \\
0.0000 \\
0.0010 \\
0.0000\end{array}$ & $\begin{array}{l}100 \\
100 \\
100 \\
100 \\
100\end{array}$ & $\begin{array}{l}0.9944 \\
0.9941 \\
0.9943 \\
0.9919 \\
0.9926\end{array}$ & $\begin{array}{l}0.0116 \\
0.0096 \\
0.0079 \\
0.0100 \\
0.0094\end{array}$ & $\begin{array}{l}100 \\
100 \\
100 \\
100 \\
100\end{array}$ \\
\hline & 500 & $\begin{array}{l}2 \\
3 \\
4 \\
5 \\
6\end{array}$ & $\begin{array}{l}1.0000 \\
1.0000 \\
1.0000 \\
1.0000 \\
1.0000\end{array}$ & $\begin{array}{l}0.0000 \\
0.0000 \\
0.0000 \\
0.0000 \\
0.0000\end{array}$ & $\begin{array}{l}100 \\
100 \\
100 \\
100 \\
100\end{array}$ & $\begin{array}{l}0.9982 \\
0.9983 \\
0.9983 \\
0.9981 \\
0.9985\end{array}$ & $\begin{array}{l}0.0048 \\
0.0038 \\
0.0038 \\
0.0039 \\
0.0036\end{array}$ & $\begin{array}{l}100 \\
100 \\
100 \\
100 \\
100\end{array}$ \\
\hline \multirow{4}{*}{$\begin{array}{l}\text { Loading } \\
=0.90\end{array}$} & 50 & $\begin{array}{l}2 \\
3 \\
4 \\
5 \\
6\end{array}$ & $\begin{array}{l}1.0000 \\
1.0000 \\
1.0000 \\
1.0000 \\
1.0000\end{array}$ & $\begin{array}{l}0.0000 \\
0.0000 \\
0.0000 \\
0.0000 \\
0.0000\end{array}$ & $\begin{array}{r}100 \\
100 \\
100 \\
98 \\
95\end{array}$ & $\begin{array}{l}0.9870 \\
0.9875 \\
0.9839 \\
0.9775 \\
0.9741\end{array}$ & $\begin{array}{l}0.0183 \\
0.0164 \\
0.0190 \\
0.0157 \\
0.0172\end{array}$ & $\begin{array}{r}99 \\
100 \\
100 \\
100 \\
100\end{array}$ \\
\hline & 100 & $\begin{array}{l}2 \\
3 \\
4 \\
5 \\
6\end{array}$ & $\begin{array}{l}1.0000 \\
1.0000 \\
1.0000 \\
1.0000 \\
1.0000\end{array}$ & $\begin{array}{l}0.0000 \\
0.0000 \\
0.0000 \\
0.0000 \\
0.0000\end{array}$ & $\begin{array}{l}100 \\
100 \\
100 \\
100 \\
100\end{array}$ & $\begin{array}{l}0.9963 \\
0.9962 \\
0.9945 \\
0.9942 \\
0.9924\end{array}$ & $\begin{array}{l}0.0075 \\
0.0063 \\
0.0070 \\
0.0079 \\
0.0079\end{array}$ & $\begin{array}{l}100 \\
100 \\
100 \\
100 \\
100\end{array}$ \\
\hline & 200 & $\begin{array}{l}2 \\
3 \\
4 \\
5 \\
6\end{array}$ & $\begin{array}{l}1.0000 \\
1.0000 \\
1.0000 \\
1.0000 \\
1.0000\end{array}$ & $\begin{array}{l}0.0000 \\
0.0000 \\
0.0000 \\
0.0000 \\
0.0000\end{array}$ & $\begin{array}{l}100 \\
100 \\
100 \\
100 \\
100\end{array}$ & $\begin{array}{l}0.9989 \\
0.9983 \\
0.9987 \\
0.9975 \\
0.9981\end{array}$ & $\begin{array}{l}0.0035 \\
0.0038 \\
0.0034 \\
0.0044 \\
0.0039\end{array}$ & $\begin{array}{l}100 \\
100 \\
100 \\
100 \\
100\end{array}$ \\
\hline & 500 & $\begin{array}{l}2 \\
3 \\
4 \\
5 \\
6\end{array}$ & $\begin{array}{l}1.0000 \\
1.0000 \\
1.0000 \\
1.0000 \\
1.0000\end{array}$ & $\begin{array}{l}0.0000 \\
0.0000 \\
0.0000 \\
0.0000 \\
0.0000\end{array}$ & $\begin{array}{l}100 \\
100 \\
100 \\
100 \\
100\end{array}$ & $\begin{array}{l}0.9997 \\
1.0000 \\
1.0000 \\
1.0000 \\
1.0000\end{array}$ & $\begin{array}{l}0.0017 \\
0.0000 \\
0.0000 \\
0.0000 \\
0.0000\end{array}$ & $\begin{array}{l}100 \\
100 \\
100 \\
100 \\
100\end{array}$ \\
\hline
\end{tabular}




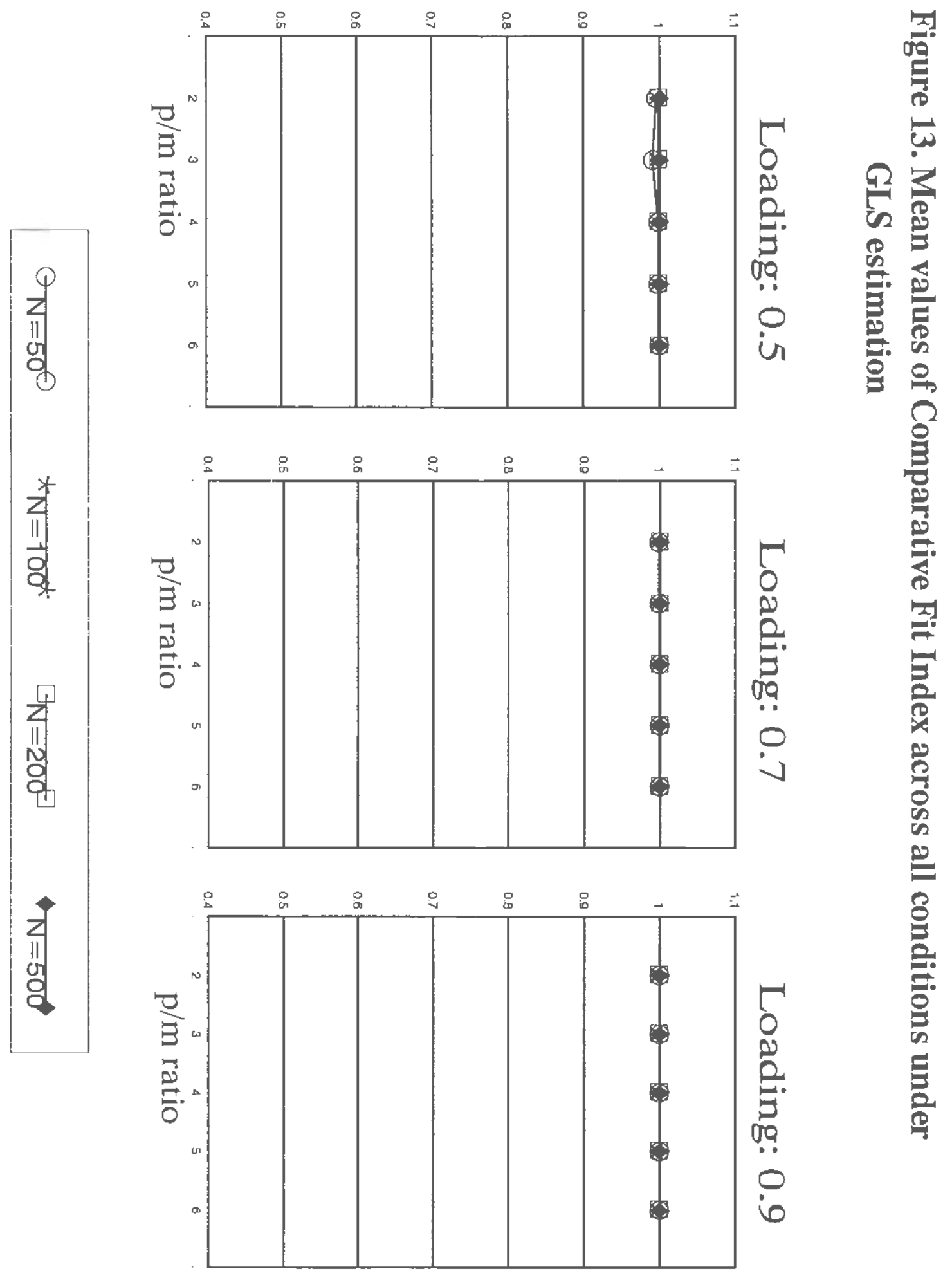




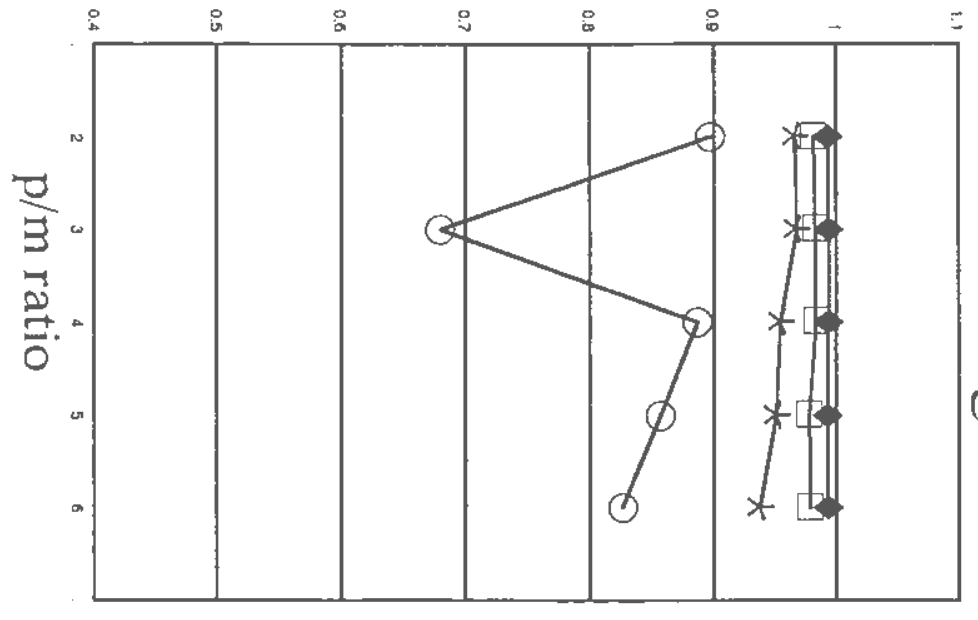

㐘

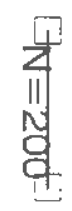
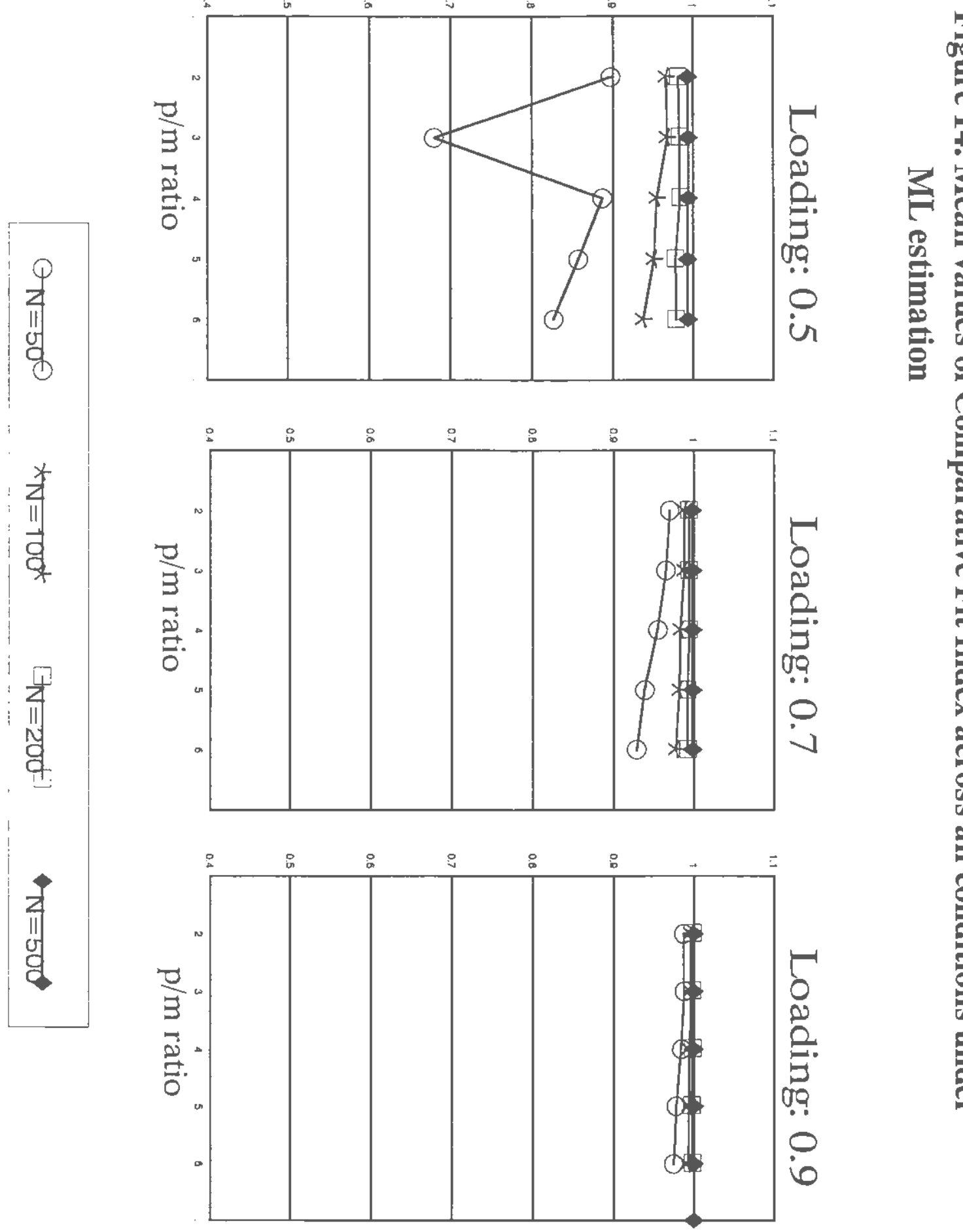

年

$\stackrel{2}{=}$

尽 


\section{Parsimonious indices}

ALL the Means and Standard Deviations for parsimonious indices are reported in Appendix B. Table B-1 for PNFI, Table B-2 for PNNFI, Table B-3 for Pd, Table B-4 for Pm, Table B-5 for PRNI, Table B-6 for PCFI. Results for PNFI is also graphed as Appendix C, Figure C-1 (GLS results) and Figure C-2 (ML results). Since all the PIs have linear relationships with the original indices, the result are not presented here, related issues will be discussed in the Discussion section.

\section{DISCUSSION}

\section{Findings and implications from this study}

Major findings from this study are presented below for each of the factors examined in this study.

Sample dependency. All the seven fit indices were influenced by sample size. However, the biases were very small for $d, m$ and three Type II incremental fit indices (NNFI, RNI, CFI) once a minimum sample size 100 is reached. There was no bias for these indices when $\mathrm{N}$ was 200 or larger. NFI produced severe bias when sample sizes were small. The influences of sample size are also reflected on the variability of the indices. The variabilities was decreased for all indices when sample size increased.

The influence of loading. NFI and CFI are the only two indices which were influenced by loading size. The downward bias under low loading conditions is big for 
NFI. The effect of loading on CFI occurred only when sample size was 50 . These findings are not in the agreement with findings from PCA/FA studies (e.g. Guadagnoli \& Velicer, 1988). The fact that the effect of loading is not as strong may partially be due to the limitations of the study design. In this study all indicators have unique loadings and the lower bound of 0.5 is large compared to that of 0.0 for most PCA/FA studies. Therefore, the low loadings may not produce enough fusion to affect the structure pattern. However, since serious bias does occur in the case of NFI, we can conclude that other indices are less affected by loading size, if at all.

The effect of $\mathbf{p} / \mathbf{m}$ ratio. Contrary to the findings from PCA/FA studies (e.g. Velicer, 1974; Velicer \& Fava, 1987, 1993; Fava \& Velicer, 1992a, 1992b), an increase of $\mathrm{p} / \mathrm{m}$ had negative effects on some of the fit indices (such as NFI, $d, m$ ). The negative effects are reflected as either a bias of the fit index value or an increased SD when $\mathrm{p} / \mathrm{m}$ becomes larger. The only benefit was found with the variability of NNFI and RNI, i.e. an increase of $\mathrm{p} / \mathrm{m}$ resulted in decreased SDs. However, this effect was small compared to the effects produced by $\mathrm{N}$ and $\mathrm{L}$. The negative effect of increased $\mathrm{p} / \mathrm{m}$ has been related to the problem of parsimony (Gerbing \& Anderson, 1993). We discuss this in more detail later. All three Type II Incremental Fit Indices (NNFI, RNI, CFI) did not show any serious bias when $\mathrm{p} / \mathrm{m}$ increased if sample size was 100 or more. The fact that they had taken $d f$ into account did a good job of decreasing this bias.

Estimation Method Specific. An interesting phenomenon is that all indices estimated under GLS were much less affected by any factors in this study than those estimated with ML. Additionally, the variability was much smaller under GLS than under 
ML. Even the NFI had very little bias under the worst conditions when GLS was used. Since our models are perfectly specified, we would expect the index to indicate a perfect fit. The less bias, the better an index is. However we can not conclude that all indices work better with the GLS estimator. Possibly the GLS estimator is generally insensitive, as La Du \& Tanaka (1989) had detected in their study. If an estimator is not sensitive to sampling error such as these produced by small sample size or low loading, it is very possible that it is also not sensitive to misspecification of the model. We could not evaluate this hypothesis because misspecification conditions were not included in this study. This issue will be investigated more thoroughly in a future study which will focus on the problem of misspecification.

In conclusion, we found that the three Type II Fit Indices (NNFI, RNI, CFI) and the noncentrality $d$ and centrality $m$ were relatively independent of sample size as long as $\mathrm{N}$ is 200 or bigger. They are also independent of loading size and $\mathrm{p} / \mathrm{m}$ ratio, once the requirement for sample size is met ( $\mathrm{N} \geq 200$ ). Among all these indices, CFI and $\mathrm{RNI}$ appear to be the two most appealing. CFI is normed, and it has the least variability. RNI had the least bias across all conditions, and its variability was small as well. However, it is important to remember that good fit indices should not only be relatively independent of factors studied here, they should also be sensitive to misspecification. Our conclusions therefore are limited by the study design.

\section{The effect of $\mathrm{p} / \mathrm{m}$ ratio and the parsimony problem.}

We have talked about the negative effect of $\mathrm{p} / \mathrm{m}$ on some fit indices and we have 
related this effect to the problem of parsimony in fit indices (James et al., 1982). However, these two are not the same things. When we talk about $\mathrm{p} / \mathrm{m}$ ratio, we are referring to a more parsimonious model or structure. PCA/FA studies (Velicer, 1974; Guadagnoli \& Velicer, 1988; Fava \& Velicer, 1992) have demonstrated that the larger the $\mathrm{p} / \mathrm{m}$ ratio, the more stable a factor pattern and the more well identified the factors are. A large $\mathrm{p} / \mathrm{m}$ ratio has produced positive effects with PCA/FA studies. Theoretically, this positive effect should exist with structural models as well. More indicators should result in better identified latent variables. A fit index should reflect this effect and produce a better fit when we hold the structure constant and have more indicators per factor. In other words, this is a question of whether a more parsimonious structural model should be rewarded. On the other hand, the parsimony problem with some fit indices, such as the NFI proposed by James et al. (1982), is actually referring to the fact that $\chi^{2}$ and NFI (or stand-alone and Type I Fit Indices in general) can be improved simply by freeing more parameters. When we free a parameter in a particular model, we are not making the structure more stable or easier to be identified, we are just increasing the error allowance for that model. Although these two problems are different in nature, they are related by the fact that the bigger the $\mathrm{p} / \mathrm{m}$ ratio, the larger the $\mathrm{df}_{\mathrm{l}} / \mathrm{df}_{\mathrm{n}}$ ratio, and the more parameters being freed in a particular model. This confusion is hard to separate in practice. The investigation of the effects of the $\mathrm{p} / \mathrm{m}$ ratio and the correctness of parsimony justification in this study leads to the following observations:

(1) In this study, all models were correctly specified and the downward bias when $\mathrm{p} / \mathrm{m}$ increased which occurred for the NFI is obviously a problem for this index. 
However, parsimonious adjusted index PNFI does not appear to be the solution for the problem (see Figure $\mathrm{C}=1$ and Figure $\mathrm{C}-2$ in appendix). The values of the PIs are largely determined by the $\mathrm{df}_{\mathrm{l}} / \mathrm{df}_{\mathrm{n}}$ ratio in a particular model. The optimal values of PIs are equal to $\mathrm{df}_{\mathrm{t}} / \mathrm{df}_{\mathrm{a}}$ ratios for indices with a upper bound value of 1 , such as NFI, $m, \mathrm{RNI}$, and CFI. For each particular $\mathrm{df}_{\mathrm{l}} / \mathrm{df}_{\mathrm{n}}$, the optimal value of PI is different. This made it very difficult to compare the fit across models. However, since NNFI, RNI and CFI are relatively unbiased against the gain of $\mathrm{p} / \mathrm{m}$, we could conclude that these fit indices overcome the problem caused by a $\mathrm{df}_{\imath} / \mathrm{df}_{\mathrm{n}}$ gain when $\mathrm{p} / \mathrm{m}$ increases. However, these indices do not reward a more parsimonious model, that is, a higher $\mathrm{p} / \mathrm{m}$ ratio does not improve the values of these fit indices.

(2) Although PIs with Incremental Fit Indices are difficult to interpret, $\mathrm{P} \chi^{2}$ in this study did correct the negative effect of $\mathrm{p} / \mathrm{m}$. Since $\chi^{2}$ is a badness-fit index, there is no requirement for a comparable optimal value across models. The findings from this study suggest that $\mathrm{P} \chi^{2}$ may be a good solution to reduce the $\chi^{2}$ statistic's tendency to reject the null hypothesis when there is indeed a good fit. However, until the behavior of $\mathrm{P}^{2}$ under misspecification conditions can be examined, no definitive conclusions can be drawn. It is possible that the reduction of $\chi^{2}$, i.e. the use of $\mathrm{P}^{2}$, also reduces the sensitivity of the $\chi^{2}$ test to real misspecification. In addition, there are other serious problems with the $\chi^{2}$ test, such as the inability to provide information with regard to the degree of fit and impact of nonnormality, which still can not be resolved.

(3) The parsimony problem (James et al., 1982) could not be adequately studied in this project because that problem is always related to misspecification. Given the same 
number of variables, if a model which has more free parameters were correct, then the other(s) would be misspecified, or vice versa. Therefore, in order to study this problem, an appropriate focus would be to compare the effect produced by the gain or loss of $d f_{t}$ to the effect produced by misspecification in a series of nested models. We would expect that a good fit index should improve more by the closeness to the correct structure than by freeing a parameter in a wrong place.

\section{Limitations of the study}

A good fit index should have a value such as 1.0 when the specified model is correct. When the specified model is incorrect, the fit index should be sensitive to the degree of misspecification and a lower fit index value, which indicates the lack of fit should be obtained. The lack of fit should be affected more by misspecification than by simple sampling error (Gerbing \& Anderson, 1993). Only if a fit index satisfies all these criteria, can an index be reliable and valuable. Because misspecification is a big issue, including misspecification would require a much larger simulation study. Since all models were accurately specified in this project, our conclusions about the performance of indices therefore were limited.

A fit index may perform excellently under the conditions of a correctly specified model and may be insensitive to misspecification. For example, when the model is misspecified, the fit index may still indicate good fit. If that occurs, the index can not be considered to be a good index. This study was not able to assess this aspect.

However, determining the performance of an index when the model is correctly 
specified is an essential first step. An ideal index should perform well for accepting the correctly specified model and rejecting a misspecified model. Poor performance under either circumstance represents a basis for rejecting that fit index. Good performance under correct specification alone is not an adequate basis for recommending an index. Poor performance, however is an adequate basis for rejecting an index.

\section{CONCLUSIONS}

Findings from this study are summaried in Table 13.

1. Overall, all seven fit indices examined in this study were affected by sample size to some degree. When sample size increased, the performance of all fit indices improved. In general, a sample size of 200 or more can produce unbiased fit for three Type II Incremental fit indices (NNFI, RNI and CFI), and two Stand-alone fit indices ( $d$ and $m$ ).

2. The reliability/loading size had a strong effect only on NFI, had a small effect on NNFI and CFI, and had no effect on Chi-square, $d, m$ and RNI. A loading size of 0.50 seems to be sufficient for fit indices studied here (except NFI) as long as the requirement for sample size $(200)$ is met.

3. The number of indicators per factor $(\mathrm{p} / \mathrm{m}$ ratio) had a negative effect on three stand-alone fit indices $\left(\chi^{2}, d, m\right)$ and Type I Incremental fit index (NFI). In general, the larger the $\mathrm{p} / \mathrm{m}$ ratio (especially when $\mathrm{p} / \mathrm{m} \geq 4$ ), the more biased the indices ( $d, m$ and 


\begin{tabular}{|c|c|c|c|c|c|c|c|}
\hline$\underline{\rho}$ & $\stackrel{\nsupseteq}{\underline{Z}}$ & $\exists$ & $\mathbf{Q}$ & $\frac{z}{\underline{Z}}$ & $\underline{z}$ & $\frac{n}{\frac{0}{0}} \stackrel{\Omega}{\frac{D}{D}}$ & ż \\
\hline 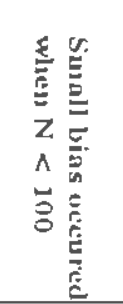 & 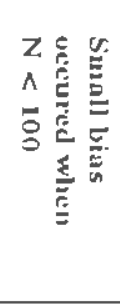 & 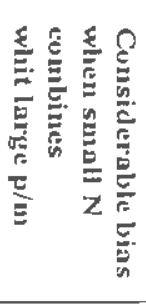 & 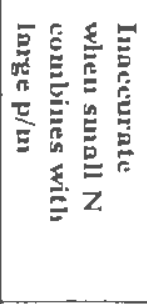 & 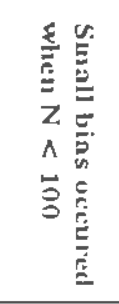 & 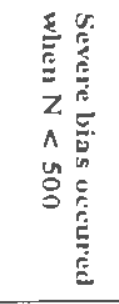 & 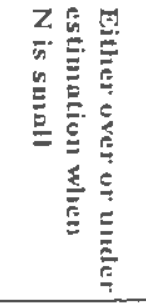 & 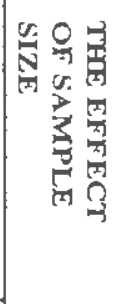 \\
\hline 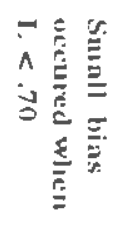 & 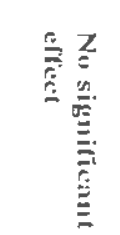 & 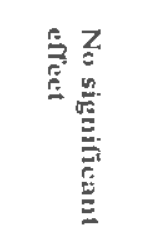 & 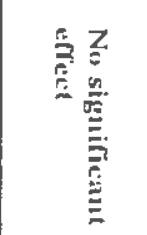 & 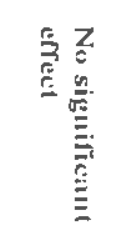 & 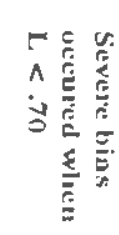 & 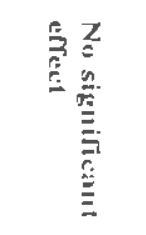 & 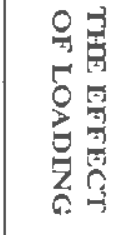 \\
\hline 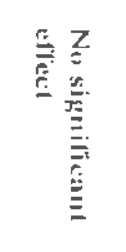 & 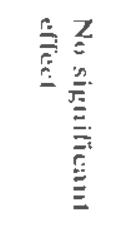 & 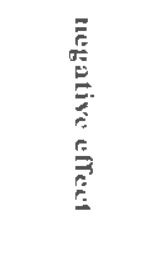 & 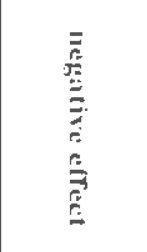 & 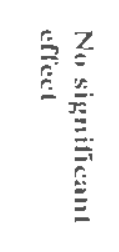 & 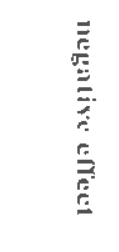 & 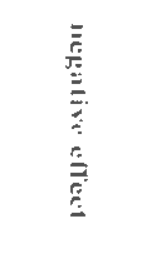 & 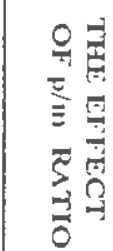 \\
\hline 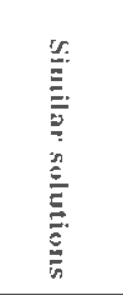 & 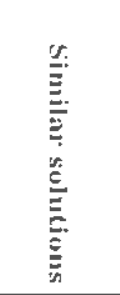 & 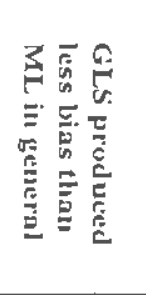 & 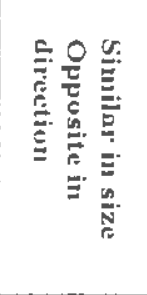 & 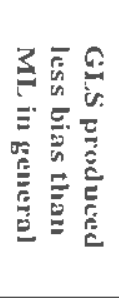 & 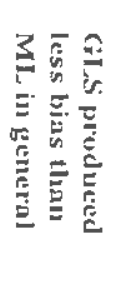 & 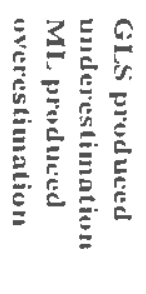 & 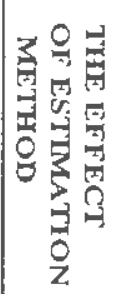 \\
\hline 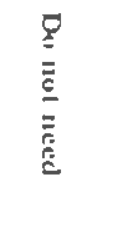 & 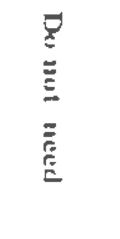 & 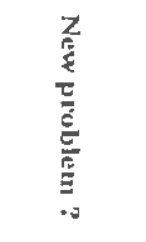 & 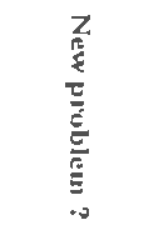 & 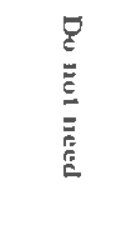 & 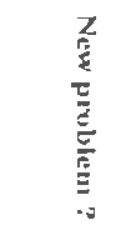 & 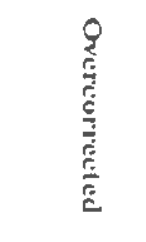 & 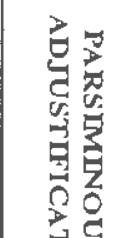 \\
\hline 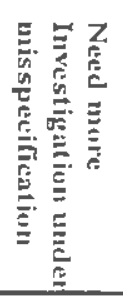 & 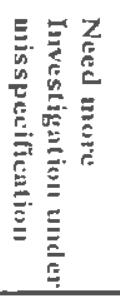 & 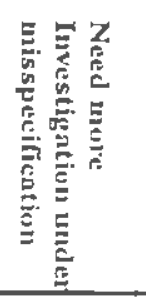 & 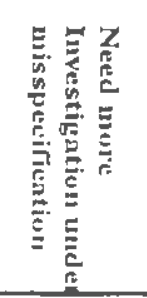 & 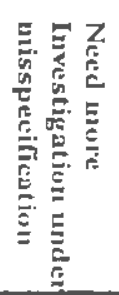 & 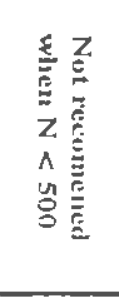 & 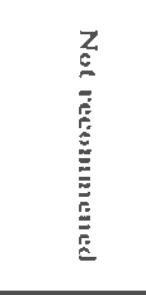 & $\begin{array}{l}8 \\
8 \\
z \\
8 \\
5 \\
0 \\
0 \\
0 \\
z \\
0\end{array}$ \\
\hline
\end{tabular}


NFI ) were, or the less accurate the indices (e.g. $\chi^{2}$ ) were. The $\mathrm{p} / \mathrm{m}$ ratio had no significant effect on three Type II Incremental fit indices (NNFI, RNI, and CFI).

4. We found that all seven fit indices were estimation method specific. Incremental fit indices from GLS were much less biased than that from ML under small to medium sample sizes ( $N \leq 200$ ). Stand-alone indices from GLS can either appear as under estimation $\left(\chi^{2}\right)$ or upward bias ( $d$ and $m$ ), while estimates from ML appear as overestimation $\left(\chi^{2}\right)$ or downward bias ( $d$ and $m$ ).

5. Chi-square $\left(\chi^{2}\right)$ appears to be a poor fit index. Even under perfect conditions, it either under estimated (with GLS) or over estimated (with ML). $\chi^{2}$ was seriously affected by sample size and $\mathrm{p} / \mathrm{m}$ ratio. When $\mathrm{N} \leq 200$ and $\mathrm{p} / \mathrm{m} \geq 4, \chi^{2}$ was very inaccurate.

6. NFI values with ML were affected by all the factors examined here. Severe bias occurred when $\mathrm{N} \leq 200$, or $\mathrm{L} \leq 0.7$ and $\mathrm{p} / \mathrm{m} \geq 3$. Even with $\mathrm{N}=500$, the bias did not completely disappear. NFI values with GLS were relatively unbiased once N reached 100 or $\mathrm{L}$ reached 0.7 .

7. NNFI values with ML were biased downward when $\mathrm{N} \leq 100$ and $\mathrm{L}=0.50$. There was no bias at all when either $N$ reached 200 or $L$ reached 0.70 . The $\mathrm{p} / \mathrm{m}$ ratio had no significant effect on NNFI. NNFI values with GLS were relatively unbiased under all conditions studied here.

8. Noncentrality $d$ Index and Centrality $m$ Index were affected by $\mathrm{p} / \mathrm{m}$ ratio when $\mathrm{N} \leq 100$. The bias increased when $\mathrm{p} / \mathrm{m}$ ratio become larger. GLS produced upward bias for these two indices while ML produced downward bias. However, once N reached 200, 
no bias occurred with either GLS or ML estimation.

9. RNI and CFI were not seriously affected by all four factors examined in this study. However, downward bias can occur under small sample size $(N \leq 100)$ when $\mathrm{ML}$ is used. There was no bias occurring when GLS was used under all conditions.

10. The sample size had a strong effect on the variabilities of all seven fit indices studied here. In general, when $\mathrm{N}$ increased, the SDs of fit indices decreased.

11. The loading size had a strong effect on the variabilities of four incremental fit indices (NFI, NNFI, RNI, and CFI). When L increased, SDs of these fit indices decreased. The loading size had no effect on the variabilities of $d$ and $m$.

12. The $\mathrm{p} / \mathrm{m}$ ratio had a strong positive effect on the variability of NNFI and a small positive effect on the variability of $\mathrm{RNI}$. When $\mathrm{p} / \mathrm{m}$ ratio goes up, the SDs of NNFI and RNI go down. The $\mathrm{p} / \mathrm{m}$ ratio had a strong negative effect on $d$ and $m$. When $\mathrm{p} / \mathrm{m}$ ratio goes up, so do the SDs of these two indices. The $\mathrm{p} / \mathrm{m}$ ratio had no effect on the variabilities of NFI and CFI.

13. GLS produced much smaller SDs for all seven fit indices than ML did in general.

14. Among all seven fit indices examined here, RNI and CFI were not only the two indices with the smallest bias, they also have the least variabilities.

15. Based on the findings from this study, we recommend that $\chi^{2}$ and NFI should not be used, due to their inaccurate and severe bias even under perfect conditions studied here. The other five fit indices (NNFI, $d, m$, RNI and CFI) were relatively unbiased once sample size was 200 or larger. However, they need to be tested for sensitivity under 
misspecification conditions.

16. Although GLS seems to produce smaller bias and smaller variabilities for all the fit indices examined in this study, this could either because GLS is more robust or because GLS is insensitive. Therefore, before these two estimators are examined under misspecification, GLS should not be assumed to be better that ML.

17. While parsimony is clearly a problem for Stand-alone indices $\left(\chi^{2}, d\right.$ and $\left.m\right)$ and Type I Incremental fit index NFI, parsimonious adjusted indices (PIs) do not appear to be the solution. This is because the optimal values of PIs varied from model to model, depending on the model's $d f_{\imath} / d f_{n}$ ratio. Type II Incremental fit indices (NNFI, RNI and CFI) do not appear to need this adjustment, because they already take $d f$ into account. 
APPENDLX A 


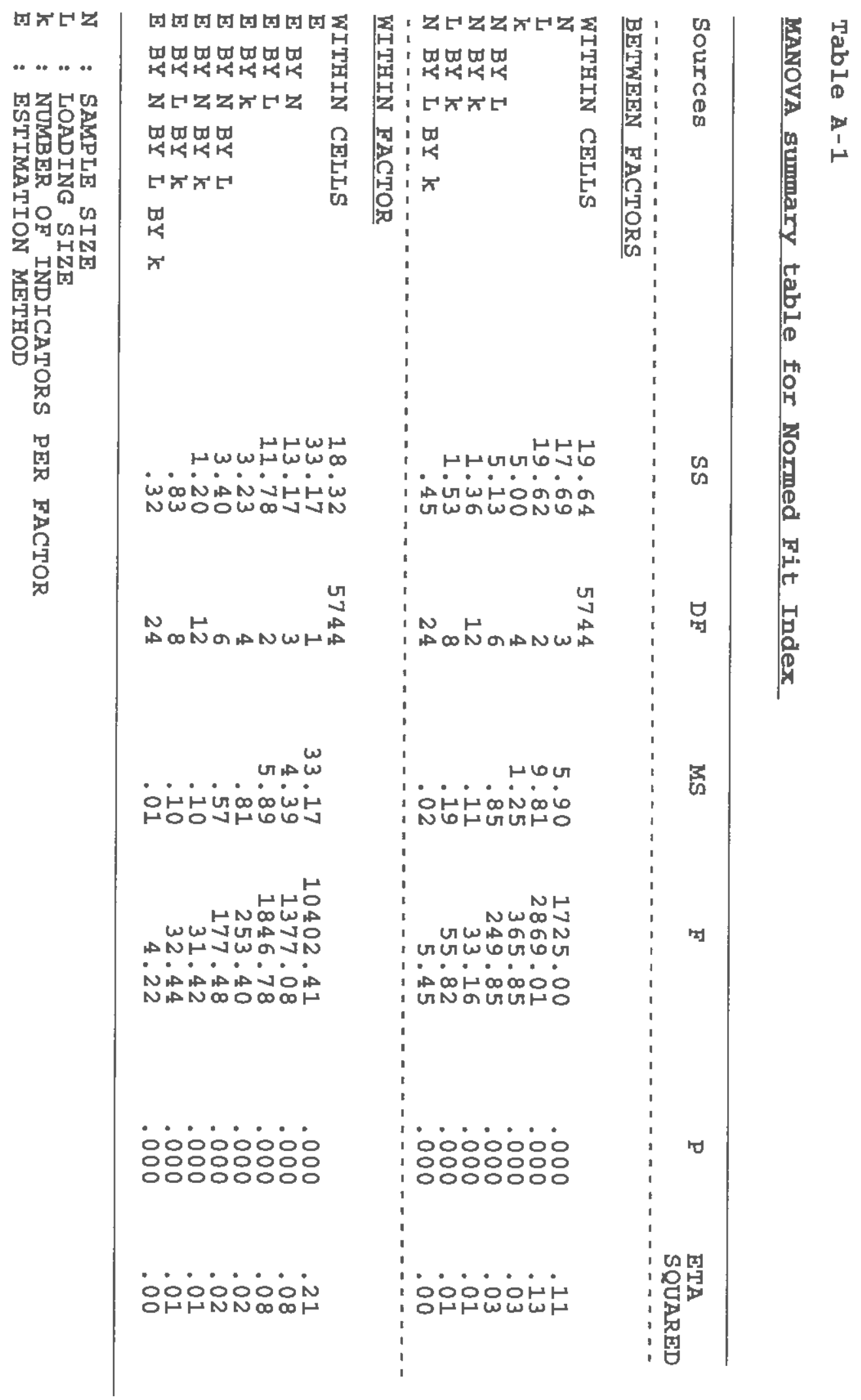




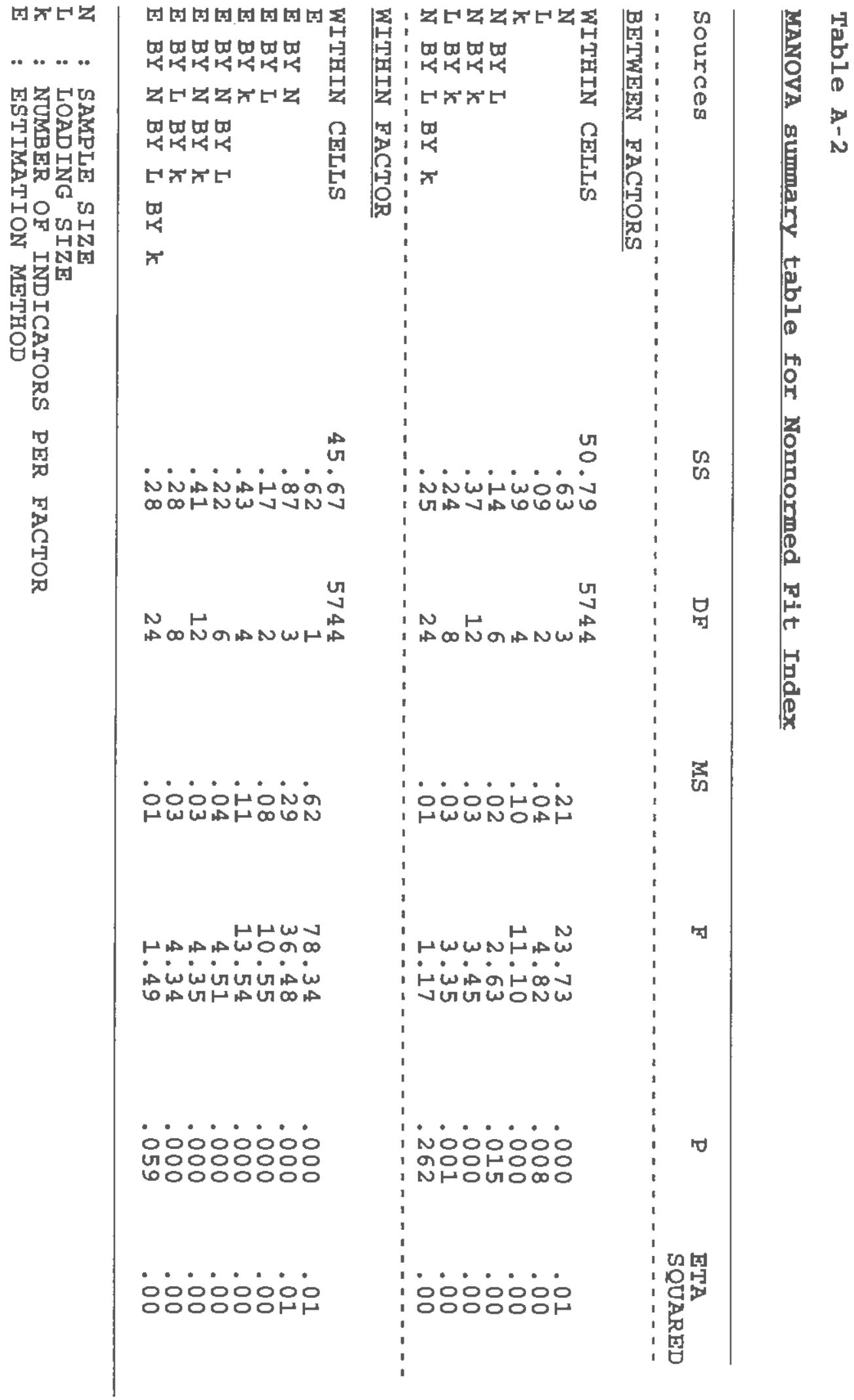




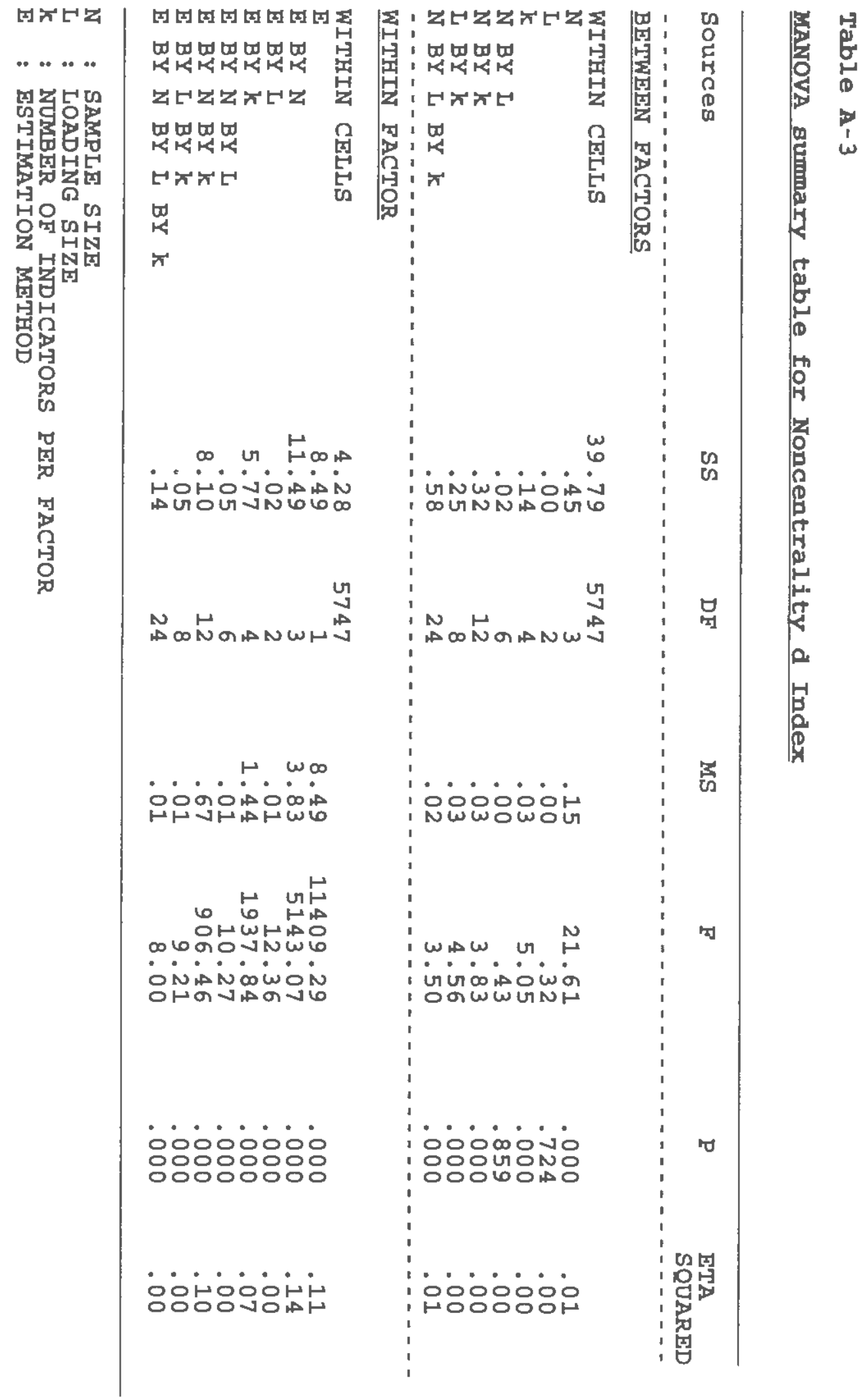




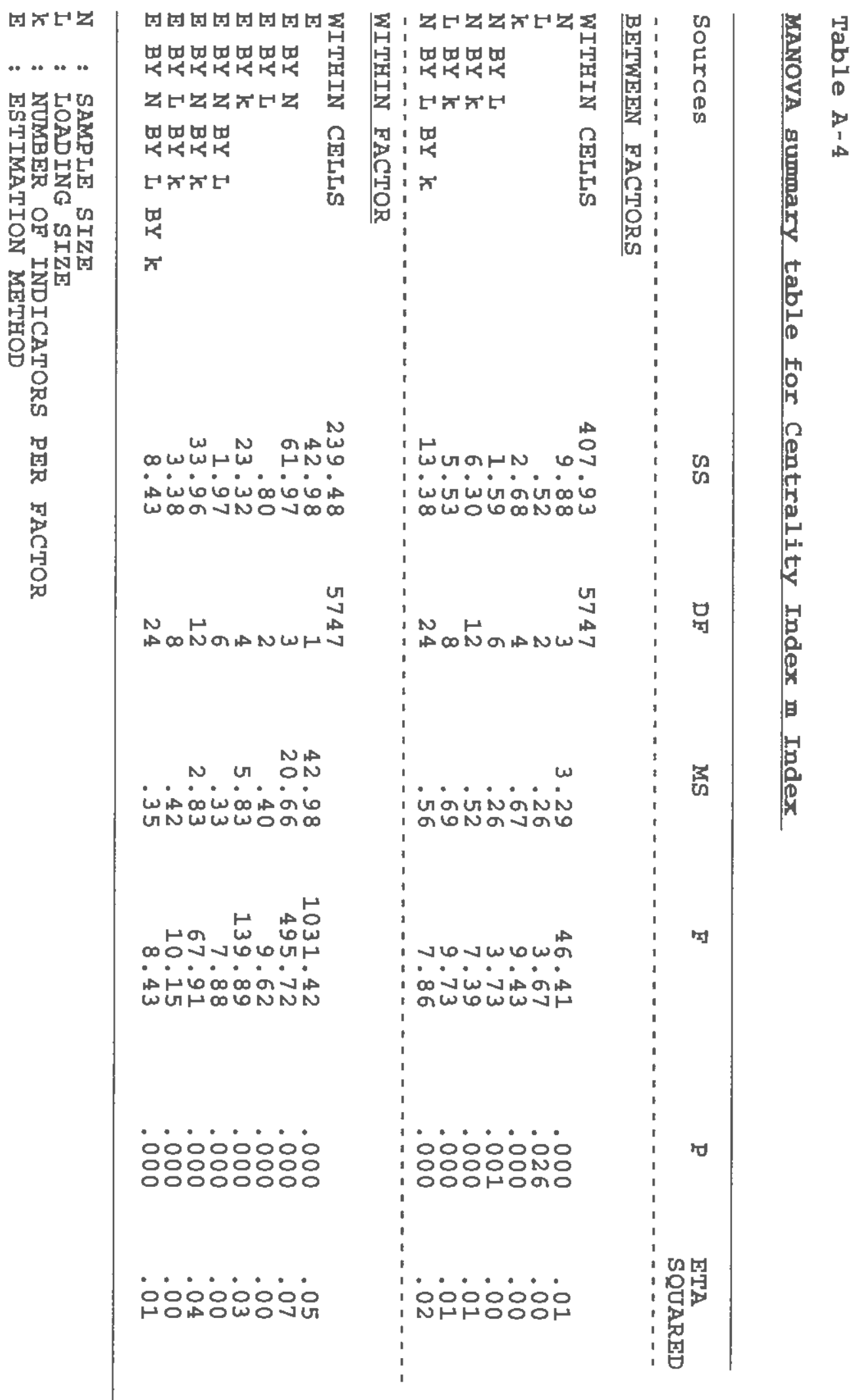




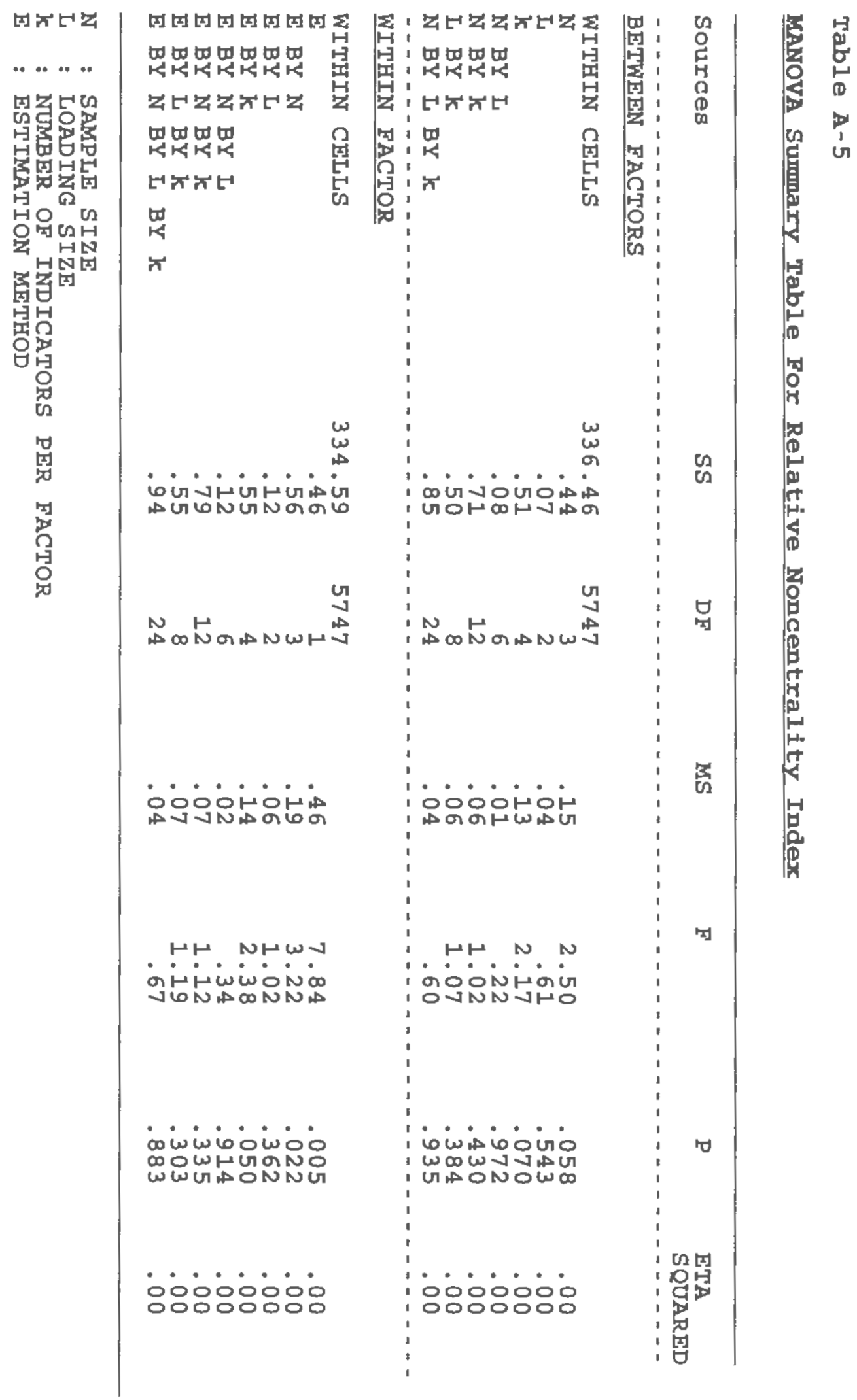




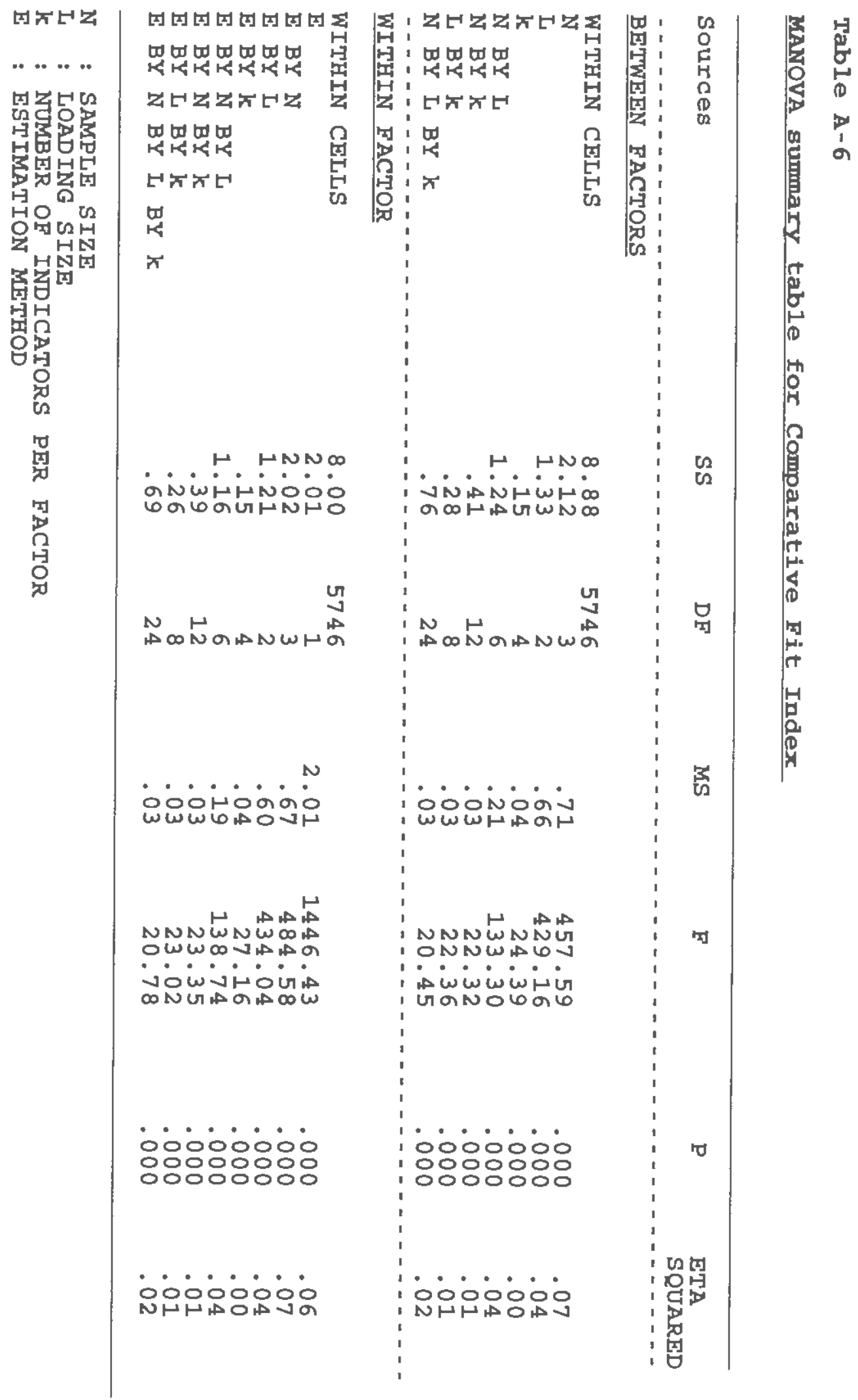


APPENDIX $\mathrm{B}$ 
Table $\mathrm{B}-1$

Means and gtandard deviations for paxgimoniougly adjusted

\begin{tabular}{|c|c|c|c|c|c|c|c|c|}
\hline & \multirow{2}{*}{$\begin{array}{l}\text { Sample } \\
\text { size }\end{array}$} & \multirow{2}{*}{$\begin{array}{l}\mathrm{p} / \mathrm{m} \\
\text { ratio }\end{array}$} & \multicolumn{3}{|c|}{ GLS } & \multicolumn{3}{|c|}{ ML } \\
\hline$\frac{S a}{s}$ & & & Mean & $S D$ & I & Mean & SD & $\mathrm{n}$ \\
\hline \multirow{4}{*}{$\begin{array}{l}\text { Loading } \\
=0.50\end{array}$} & 50 & $\begin{array}{l}2 \\
3 \\
4 \\
5 \\
6\end{array}$ & $\begin{array}{l}0.4557 \\
0.6630 \\
0.7539 \\
0.7986 \\
0.8337\end{array}$ & $\begin{array}{l}0.0052 \\
0.0112 \\
0.0059 \\
0.0082 \\
0.0056\end{array}$ & $\begin{array}{l}93 \\
69 \\
90 \\
37 \\
7 \mathrm{~B}\end{array}$ & $\begin{array}{l}0.3594 \\
0.8862 \\
0.4547 \\
0.4296 \\
0.4127\end{array}$ & $\begin{array}{l}0.0502 \\
4.2023 \\
0.0659 \\
0.0624 \\
0.0553\end{array}$ & $\begin{array}{l}97 \\
55 \\
95 \\
27 \\
99\end{array}$ \\
\hline & 100 & $\begin{array}{l}2 \\
3 \\
4 \\
5 \\
6\end{array}$ & $\begin{array}{l}0.4600 \\
0.6765 \\
0.7594 \\
0.8027 \\
0.8291\end{array}$ & $\begin{array}{l}0.0020 \\
0.0048 \\
0.0047 \\
0.0057 \\
0.0050\end{array}$ & $\begin{array}{r}97 \\
100 \\
99 \\
98 \\
97\end{array}$ & $\begin{array}{l}0.4045 \\
0.5455 \\
0.5696 \\
0.5688 \\
0.5609\end{array}$ & $\begin{array}{l}0.0332 \\
0.0424 \\
0.0413 \\
0.0479 \\
0.0470\end{array}$ & $\begin{array}{r}99 \\
99 \\
100 \\
100 \\
100\end{array}$ \\
\hline & 200 & $\begin{array}{l}2 \\
3 \\
4 \\
5 \\
6\end{array}$ & $\begin{array}{l}0.4611 \\
0.6843 \\
0.7701 \\
0.8145 \\
0.8410\end{array}$ & $\begin{array}{l}0.0031 \\
0.0052 \\
0.0017 \\
0.0052 \\
0.0033\end{array}$ & $\begin{array}{r}100 \\
99 \\
100 \\
100 \\
100\end{array}$ & $\begin{array}{l}0.4319 \\
0.6086 \\
0.6628 \\
0.6753 \\
0.6854\end{array}$ & $\begin{array}{l}0.0186 \\
0.0255 \\
0.0223 \\
0.0290 \\
0.0268\end{array}$ & $\begin{array}{l}100 \\
100 \\
100 \\
100 \\
100\end{array}$ \\
\hline & 500 & $\begin{array}{l}2 \\
3 \\
4 \\
5 \\
6\end{array}$ & $\begin{array}{l}0.4671 \\
0.6900 \\
0.7800 \\
0.8292 \\
0.8559\end{array}$ & $\begin{array}{l}0.0046 \\
0.0000 \\
0.0000 \\
0.0027 \\
0.0049\end{array}$ & $\begin{array}{ll}1 & 00 \\
1 & 00 \\
1 & 00 \\
1 & 00 \\
1 & 00\end{array}$ & $\begin{array}{l}0.4533 \\
0.6553 \\
0.7313 \\
0.7656 \\
0.7843\end{array}$ & $\begin{array}{l}0.0083 \\
0.0108 \\
0.0109 \\
0.0123 \\
0.0129\end{array}$ & $\begin{array}{l}100 \\
100 \\
100 \\
100 \\
100\end{array}$ \\
\hline \multirow{4}{*}{$\begin{array}{l}\text { Loading } \\
=0.70\end{array}$} & 50 & $\begin{array}{l}2 \\
3 \\
4 \\
5 \\
6\end{array}$ & $\begin{array}{l}0.4599 \\
0.6811 \\
0.7704 \\
0.8198 \\
0.8520\end{array}$ & $\begin{array}{l}0.0017 \\
0.0042 \\
0.0043 \\
0.0041 \\
0.0045\end{array}$ & $\begin{array}{r}100 \\
100 \\
99 \\
98 \\
94\end{array}$ & $\begin{array}{l}0.4192 \\
0.5755 \\
0.6126 \\
0.6121 \\
0.6087\end{array}$ & $\begin{array}{l}0.0244 \\
0.0354 \\
0.0390 \\
0.0325 \\
0.0380\end{array}$ & $\begin{array}{l}100 \\
100 \\
100 \\
100 \\
100\end{array}$ \\
\hline & 100 & $\begin{array}{l}2 \\
3 \\
4 \\
5 \\
6\end{array}$ & $\begin{array}{l}0.4610 \\
0.6861 \\
0.7733 \\
0.8203 \\
0.8491\end{array}$ & $\begin{array}{l}0.0030 \\
0.0049 \\
0.0047 \\
0.0030 \\
0.0032\end{array}$ & $\begin{array}{l}100 \\
100 \\
100 \\
100 \\
100\end{array}$ & $\begin{array}{l}0.4420 \\
0.6319 \\
0.6925 \\
0.7159 \\
0.7239\end{array}$ & $\begin{array}{l}0.0131 \\
0.0187 \\
0.0192 \\
0.0223 \\
0.0227\end{array}$ & $\begin{array}{l}100 \\
100 \\
100 \\
100 \\
100\end{array}$ \\
\hline & 200 & $\begin{array}{l}2 \\
3 \\
4 \\
5 \\
6\end{array}$ & $\begin{array}{l}0.4652 \\
0.6898 \\
0.7800 \\
0.8282 \\
0.8559\end{array}$ & $\begin{array}{l}0.0050 \\
0.0014 \\
0.0000 \\
0.0039 \\
0.0049\end{array}$ & $\begin{array}{l}100 \\
100 \\
100 \\
100 \\
100\end{array}$ & $\begin{array}{l}0.4542 \\
0.6620 \\
0.7388 \\
0.7730 \\
0.7930\end{array}$ & $\begin{array}{l}0.0073 \\
0.0102 \\
0.0092 \\
0.0118 \\
0.0112\end{array}$ & $\begin{array}{l}100 \\
100 \\
100 \\
100 \\
100\end{array}$ \\
\hline & 500 & $\begin{array}{l}2 \\
3 \\
4 \\
5 \\
6\end{array}$ & $\begin{array}{l}0.4695 \\
0.6900 \\
0.7805 \\
0.8300 \\
0.8600\end{array}$ & $\begin{array}{l}0.0022 \\
0.0000 \\
0.0022 \\
0.0000 \\
0.0000\end{array}$ & $\begin{array}{l}100 \\
100 \\
100 \\
100 \\
100\end{array}$ & $\begin{array}{l}0.4604 \\
0.6812 \\
0.76 .81 \\
0.8123 \\
0.8377\end{array}$ & $\begin{array}{l}0.0037 \\
0.0048 \\
0.0044 \\
0.0053 \\
0.0049\end{array}$ & $\begin{array}{l}100 \\
100 \\
100 \\
100 \\
100\end{array}$ \\
\hline \multirow{4}{*}{$\begin{array}{l}\text { Goading } \\
=0.90\end{array}$} & 50 & $\begin{array}{l}2 \\
3 \\
4 \\
5 \\
6\end{array}$ & $\begin{array}{l}0.4687 \\
0.6900 \\
0.7875 \\
0.8374 \\
0.8699\end{array}$ & $\begin{array}{l}0.0034 \\
0.0000 \\
0.0044 \\
0.0044 \\
0.0010\end{array}$ & $\begin{array}{r}100 \\
100 \\
100 \\
98 \\
95\end{array}$ & $\begin{array}{l}0.4476 \\
0.6478 \\
0.7170 \\
0.7437 \\
0.7547\end{array}$ & $\begin{array}{l}0.0104 \\
0.0138 \\
0.0158 \\
0.0137 \\
0.0164\end{array}$ & $\begin{array}{l}99 \\
100 \\
100 \\
100 \\
100\end{array}$ \\
\hline & 100 & $\begin{array}{l}2 \\
3 \\
4 \\
5 \\
6\end{array}$ & $\begin{array}{l}0.4699 \\
0.6900 \\
0.7896 \\
0.8382 \\
0.8699\end{array}$ & $\begin{array}{l}0.0010 \\
0.0000 \\
0.0020 \\
0.0039 \\
0.0010\end{array}$ & $\begin{array}{l}100 \\
100 \\
100 \\
100 \\
100\end{array}$ & $\begin{array}{l}0.4580 \\
0.6725 \\
0.7525 \\
0.7924 \\
0.8121\end{array}$ & $\begin{array}{l}0.0040 \\
0.0069 \\
0.0074 \\
0.0090 \\
0.0087\end{array}$ & $\begin{array}{l}100 \\
100 \\
100 \\
100 \\
100\end{array}$ \\
\hline & 200 & $\begin{array}{l}2 \\
3 \\
4 \\
5 \\
6\end{array}$ & $\begin{array}{l}0.4700 \\
0.6900 \\
0.7900 \\
0.8400 \\
0.8700\end{array}$ & $\begin{array}{l}0.0000 \\
0.0000 \\
0.0000 \\
0.0000 \\
0.0000\end{array}$ & $\begin{array}{l}100 \\
100 \\
100 \\
100 \\
100\end{array}$ & $\begin{array}{l}0.4606 \\
0.6831 \\
0.7697 \\
0.8153 \\
0.8412\end{array}$ & $\begin{array}{l}0.0028 \\
0.0051 \\
0.0030 \\
0.0052 \\
0.0041\end{array}$ & $\begin{array}{l}100 \\
100 \\
100 \\
100 \\
100\end{array}$ \\
\hline & 500 & $\begin{array}{l}2 \\
3 \\
4 \\
5 \\
6\end{array}$ & $\begin{array}{l}0.4700 \\
0.6900 \\
0.7900 \\
0.8400 \\
0.8700\end{array}$ & $\begin{array}{l}0.0000 \\
0.0000 \\
0.0000 \\
0.0000 \\
0.0000\end{array}$ & $\begin{array}{l}100 \\
100 \\
100 \\
100 \\
100\end{array}$ & $\begin{array}{l}0.4657 \\
0.6900 \\
0.7800 \\
0.8300 \\
0.8598\end{array}$ & $\begin{array}{l}0.0050 \\
0.0000 \\
0.0000 \\
0.0000 \\
0.0014\end{array}$ & $\begin{array}{l}100 \\
100 \\
100 \\
100 \\
100\end{array}$ \\
\hline
\end{tabular}


Table B-2

Means and standard deviationg for parsimoniously adjusted

Nonnormed Fit Index

\begin{tabular}{|c|c|c|c|c|c|c|c|c|}
\hline & \multirow{2}{*}{$\begin{array}{l}\text { Sample } \\
\text { size }\end{array}$} & \multirow{2}{*}{$\begin{array}{l}\text { p/m } \\
\text { ratio }\end{array}$} & \multicolumn{3}{|c|}{ GLS } & \multicolumn{3}{|c|}{$\mathbf{M L}$} \\
\hline & & & Mean & SD & n & Mean & SD & In \\
\hline \multirow{4}{*}{$\begin{array}{l}\text { Loading } \\
=0.50\end{array}$} & 50 & $\begin{array}{l}2 \\
3 \\
4 \\
5 \\
6\end{array}$ & $\begin{array}{l}0.4671 \\
0.6925 \\
0.7959 \\
0.8432 \\
0.8783\end{array}$ & $\begin{array}{l}0.0111 \\
0.0159 \\
0.0104 \\
0.0108 \\
0.0069\end{array}$ & $\begin{array}{l}93 \\
69 \\
90 \\
37 \\
78\end{array}$ & $\begin{array}{l}0.3906 \\
0.8111 \\
0.7275 \\
0.7319 \\
0.7144\end{array}$ & $\begin{array}{l}0.3748 \\
3.9163 \\
0.2187 \\
0.1576 \\
0.1170\end{array}$ & $\begin{array}{l}97 \\
55 \\
95 \\
27 \\
99\end{array}$ \\
\hline & 100 & $\begin{array}{l}2 \\
3 \\
4 \\
5 \\
6\end{array}$ & $\begin{array}{l}0.4681 \\
0.6976 \\
0.7903 \\
0.8420 \\
0.8720\end{array}$ & $\begin{array}{l}0.0067 \\
0.0079 \\
0.0081 \\
0.0077 \\
0.0066\end{array}$ & $\begin{array}{r}97 \\
100 \\
99 \\
98 \\
97\end{array}$ & $\begin{array}{l}0.4735 \\
0.7070 \\
0.7688 \\
0.8148 \\
0.8213\end{array}$ & $\begin{array}{l}0.1033 \\
0.0981 \\
0.0814 \\
0.0965 \\
0.0708\end{array}$ & $\begin{array}{r}99 \\
99 \\
100 \\
100 \\
100\end{array}$ \\
\hline & 200 & $\begin{array}{l}2 \\
3 \\
4 \\
5 \\
6\end{array}$ & $\begin{array}{l}0.4672 \\
0.6958 \\
0.7884 \\
0.8388 \\
0.8706\end{array}$ & $\begin{array}{l}0.0049 \\
0.0054 \\
0.0044 \\
0.0059 \\
0.0045\end{array}$ & $\begin{array}{r}100 \\
99 \\
100 \\
100 \\
100\end{array}$ & $\begin{array}{l}0.4664 \\
0.6977 \\
0.7827 \\
0.8295 \\
0.8595\end{array}$ & $\begin{array}{l}0.0505 \\
0.0461 \\
0.0325 \\
0.0401 \\
0.0367\end{array}$ & $\begin{array}{l}100 \\
100 \\
100 \\
100 \\
100\end{array}$ \\
\hline & 500 & $\begin{array}{l}2 \\
3 \\
4 \\
5 \\
6\end{array}$ & $\begin{array}{l}0.4689 \\
0.6941 \\
0.7894 \\
0.8396 \\
0.6699\end{array}$ & $\begin{array}{l}0.0031 \\
0.0049 \\
0.0024 \\
0.0020 \\
0.0010\end{array}$ & $\begin{array}{l}100 \\
100 \\
100 \\
100 \\
100\end{array}$ & $\begin{array}{l}0.4692 \\
0.6946 \\
0.7866 \\
0.8372 \\
0.8684\end{array}$ & $\begin{array}{l}0.0195 \\
0.0160 \\
0.0133 \\
0.0153 \\
0.0135\end{array}$ & $\begin{array}{l}100 \\
100 \\
100 \\
100 \\
100\end{array}$ \\
\hline \multirow{4}{*}{$\begin{array}{l}\text { Loading } \\
=0.70\end{array}$} & 50 & $\begin{array}{l}2 \\
3 \\
4 \\
5 \\
6\end{array}$ & $\begin{array}{l}0.4684 \\
0.6975 \\
0.7913 \\
0.8413 \\
0.8722\end{array}$ & $\begin{array}{l}0.0071 \\
0.0059 \\
0.0060 \\
0.0045 \\
0.0042\end{array}$ & $\begin{array}{r}100 \\
100 \\
99 \\
98 \\
94\end{array}$ & $\begin{array}{l}0.4655 \\
0.6771 \\
0.7550 \\
0.7854 \\
0.8044\end{array}$ & $\begin{array}{l}0.0706 \\
0.0613 \\
0.0647 \\
0.0500 \\
0.0489\end{array}$ & $\begin{array}{l}100 \\
100 \\
100 \\
100 \\
100\end{array}$ \\
\hline & 100 & $\begin{array}{l}2 \\
3 \\
4 \\
5 \\
6\end{array}$ & $\begin{array}{l}0.4677 \\
0.6960 \\
0.7894 \\
0.8398 \\
0.8700\end{array}$ & $\begin{array}{l}0.0045 \\
0.0049 \\
0.0042 \\
0.0038 \\
0.0025\end{array}$ & $\begin{array}{l}100 \\
100 \\
100 \\
100 \\
100\end{array}$ & $\begin{array}{l}0.4684 \\
0.6947 \\
0.7791 \\
0.8270 \\
0.8501\end{array}$ & $\begin{array}{l}0.0305 \\
0.0299 \\
0.0281 \\
0.0291 \\
0.0253\end{array}$ & $\begin{array}{l}100 \\
100 \\
100 \\
100 \\
100\end{array}$ \\
\hline & 200 & $\begin{array}{l}2 \\
3 \\
4 \\
5 \\
6\end{array}$ & $\begin{array}{l}0.4684 \\
0.6951 \\
0.7895 \\
0.8392 \\
0.8702\end{array}$ & $\begin{array}{l}0.0037 \\
0.0050 \\
0.0022 \\
0.0027 \\
0.0014\end{array}$ & $\begin{array}{l}100 \\
100 \\
100 \\
100 \\
100\end{array}$ & $\begin{array}{l}0.4673 \\
0.6949 \\
0.7860 \\
0.8339 \\
0.8652\end{array}$ & $\begin{array}{l}0.0159 \\
0.0150 \\
0.0113 \\
0.0142 \\
0.0128\end{array}$ & $\begin{array}{l}100 \\
100 \\
100 \\
100 \\
100\end{array}$ \\
\hline & 500 & $\begin{array}{l}2 \\
3 \\
4 \\
5 \\
6\end{array}$ & $\begin{array}{l}0.4695 \\
0.6920 \\
0.7900 \\
0.8400 \\
0.8700\end{array}$ & $\begin{array}{l}0.0022 \\
0.0045 \\
0.0000 \\
0.0000 \\
0.0000\end{array}$ & $\begin{array}{l}100 \\
100 \\
100 \\
100 \\
100\end{array}$ & $\begin{array}{l}0.4675 \\
0.6941 \\
0.7873 \\
0.9390 \\
0.9694\end{array}$ & $\begin{array}{l}0.0072 \\
0.0059 \\
0.0049 \\
0.0062 \\
0.0051\end{array}$ & $\begin{array}{l}100 \\
100 \\
100 \\
100 \\
100\end{array}$ \\
\hline \multirow{4}{*}{$\begin{array}{l}\text { Loading } \\
=0.90\end{array}$} & 50 & $\begin{array}{l}2 \\
3 \\
4 \\
5 \\
6\end{array}$ & $\begin{array}{l}0.4693 \\
0.6945 \\
0.7900 \\
0.8400 \\
0.8700\end{array}$ & $\begin{array}{l}0.0026 \\
0.0050 \\
0.0000 \\
0.0000 \\
0.0000\end{array}$ & $\begin{array}{r}100 \\
100 \\
100 \\
99 \\
95\end{array}$ & $\begin{array}{l}0.4597 \\
0.6871 \\
0.7760 \\
0.8186 \\
0.8456\end{array}$ & $\begin{array}{l}0.0236 \\
0.0209 \\
0.0221 \\
0.0174 \\
0.0181\end{array}$ & $\begin{array}{r}99 \\
100 \\
100 \\
100 \\
100\end{array}$ \\
\hline & 100 & $\begin{array}{l}2 \\
3 \\
4 \\
5 \\
6\end{array}$ & $\begin{array}{l}0.4698 \\
0.6923 \\
0.7900 \\
0.8400 \\
0.8700\end{array}$ & $\begin{array}{l}0.0014 \\
0.0042 \\
0.0000 \\
0.0000 \\
0.0000\end{array}$ & $\begin{array}{l}100 \\
100 \\
100 \\
100 \\
100\end{array}$ & $\begin{array}{l}0.4670 \\
0.6940 \\
0.7851 \\
0.8341 \\
0.8630\end{array}$ & $\begin{array}{l}0.0107 \\
0.0098 \\
0.0099 \\
0.0100 \\
0.0093\end{array}$ & $\begin{array}{l}100 \\
100 \\
100 \\
100 \\
100\end{array}$ \\
\hline & 200 & $\begin{array}{l}2 \\
3 \\
4 \\
5 \\
6\end{array}$ & $\begin{array}{l}0.4699 \\
0.6905 \\
0.7900 \\
0.8400 \\
0.8700\end{array}$ & $\begin{array}{l}0.0010 \\
0.0022 \\
0.0000 \\
0.0000 \\
0.0000\end{array}$ & $\begin{array}{l}100 \\
100 \\
100 \\
100 \\
100\end{array}$ & $\begin{array}{l}0.4671 \\
0.6948 \\
0.7874 \\
0.8363 \\
0.8685\end{array}$ & $\begin{array}{l}0.0050 \\
0.0058 \\
0.0044 \\
0.0053 \\
0.0054\end{array}$ & $\begin{array}{l}100 \\
100 \\
100 \\
100 \\
100\end{array}$ \\
\hline & 500 & $\begin{array}{l}2 \\
3 \\
4 \\
5 \\
6\end{array}$ & $\begin{array}{l}0.4700 \\
0.6900 \\
0.7900 \\
0.9400 \\
0.8700\end{array}$ & $\begin{array}{l}0.0000 \\
0.0000 \\
0.0000 \\
0.0000 \\
0.0000\end{array}$ & $\begin{array}{l}100 \\
100 \\
100 \\
100 \\
100\end{array}$ & $\begin{array}{l}0.4681 \\
0.6936 \\
0.7895 \\
0.8397 \\
0.8698\end{array}$ & $\begin{array}{l}0.0039 \\
0.0049 \\
0.0022 \\
0.0017 \\
0.0014\end{array}$ & $\begin{array}{l}100 \\
100 \\
100 \\
100 \\
100\end{array}$ \\
\hline
\end{tabular}


Table B-3

Means and standard deviations for parsimoniously adjusted Noncentrality d Index

\begin{tabular}{|c|c|c|c|c|c|c|c|c|}
\hline & \multirow{2}{*}{$\begin{array}{l}\text { Sample } \\
\text { size }\end{array}$} & \multirow{2}{*}{$\begin{array}{l}\mathrm{p} / \mathrm{m} \\
\text { ratio }\end{array}$} & \multicolumn{3}{|c|}{ GLSS } & \multicolumn{3}{|c|}{ MI } \\
\hline & & & Mean & SD & n & Mean & $\mathrm{SD}$ & $\mathrm{n}$ \\
\hline \multirow{4}{*}{$\begin{array}{l}\text { Loading } \\
=0.50^{\circ}\end{array}$} & 50 & $\begin{array}{l}2 \\
3 \\
4 \\
5 \\
6\end{array}$ & $\begin{array}{r}0.0029 \\
0.0307 \\
-0.0842 \\
-0.0976 \\
-0.2986\end{array}$ & $\begin{array}{l}0.0309 \\
0.1277 \\
0.1462 \\
0.2323 \\
0.2280\end{array}$ & $\begin{array}{l}93 \\
69 \\
90 \\
37 \\
78\end{array}$ & $\begin{array}{l}0.0158 \\
0.6171 \\
0.1209 \\
0.2385 \\
0.4676\end{array}$ & $\begin{array}{l}0.0437 \\
1.9987 \\
0.1974 \\
0.2539 \\
0.3162\end{array}$ & $\begin{array}{l}97 \\
58 \\
95 \\
27 \\
99\end{array}$ \\
\hline & 100 & $\begin{array}{l}2 \\
3 \\
4 \\
5 \\
6\end{array}$ & $\begin{array}{l}-0.0027 \\
-0.0158 \\
-0.0179 \\
-0.0450 \\
-0.0413\end{array}$ & $\begin{array}{l}0.0125 \\
0.0394 \\
0.0757 \\
0.1157 \\
0.1293\end{array}$ & $\begin{array}{r}97 \\
100 \\
99 \\
98 \\
97\end{array}$ & $\begin{array}{r}0.0001 \\
0.0004 \\
0.0311 \\
0.0506 \\
0.1260\end{array}$ & $\begin{array}{l}0.0147 \\
0.0492 \\
0.0866 \\
0.1318 \\
0.1553\end{array}$ & $\begin{array}{r}99 \\
99 \\
100 \\
100 \\
100\end{array}$ \\
\hline & 200 & $\begin{array}{l}2 \\
3 \\
4 \\
5 \\
6\end{array}$ & $\begin{array}{r}0.0003 \\
-0.0043 \\
-0.0052 \\
-0.0060 \\
-0.0132\end{array}$ & $\begin{array}{l}0.0092 \\
0.0237 \\
0.0331 \\
0.0583 \\
0.0696\end{array}$ & $\begin{array}{r}100 \\
99 \\
100 \\
100 \\
100\end{array}$ & $\begin{array}{r}0.0009 \\
0.0011 \\
0.0074 \\
0.0 .179 \\
0.0258\end{array}$ & $\begin{array}{l}0.0100 \\
0.0255 \\
0.0345 \\
0.0610 \\
0.0822\end{array}$ & $\begin{array}{l}100 \\
100 \\
100 \\
100 \\
100\end{array}$ \\
\hline & 500 & $\begin{array}{l}2 \\
3 \\
4 \\
5 \\
6\end{array}$ & $\begin{array}{r}0.0006 \\
-0.0007 \\
-0.0009 \\
-0.0027 \\
-0.0036\end{array}$ & $\begin{array}{l}0.0031 \\
0.0093 \\
0.0139 \\
0.0228 \\
0.0301\end{array}$ & $\begin{array}{l}100 \\
100 \\
100 \\
100 \\
100\end{array}$ & $\begin{array}{l}0.0007 \\
0.0000 \\
0.0013 \\
0.0020 \\
0.0016\end{array}$ & $\begin{array}{l}0.0033 \\
0.0093 \\
0.0137 \\
0.0242 \\
0.0299\end{array}$ & $\begin{array}{l}100 \\
100 \\
100 \\
100 \\
100\end{array}$ \\
\hline \multirow{4}{*}{$\begin{array}{l}\text { Loading } \\
=0.70\end{array}$} & 50 & $\begin{array}{l}2 \\
3 \\
4 \\
5 \\
6\end{array}$ & $\begin{array}{l}-0.0055 \\
-0.0354 \\
-0.0620 \\
-0.1338 \\
-0.2669\end{array}$ & $\begin{array}{l}0.0282 \\
0.0924 \\
0.1534 \\
0.1954 \\
0.2254\end{array}$ & $\begin{array}{r}100 \\
100 \\
99 \\
98 \\
94\end{array}$ & $\begin{array}{l}0.0058 \\
0.0416 \\
0.1312 \\
0.2911 \\
0.4789\end{array}$ & $\begin{array}{l}0.0371 \\
0.1112 \\
0.2009 \\
0.2400 \\
0.3198\end{array}$ & $\begin{array}{l}100 \\
100 \\
100 \\
100 \\
100\end{array}$ \\
\hline & 100 & $\begin{array}{l}2 \\
3 \\
4 \\
5 \\
6\end{array}$ & $\begin{array}{l}-0.0022 \\
-0.0141 \\
-0.0125 \\
-0.0378 \\
-0.0371\end{array}$ & $\begin{array}{l}0.0162 \\
0.0382 \\
0.0775 \\
0.1179 \\
0.1288\end{array}$ & $\begin{array}{l}100 \\
100 \\
100 \\
100 \\
100\end{array}$ & $\begin{array}{l}0.0003 \\
0.0030 \\
0.0339 \\
0.0578 \\
0.1306\end{array}$ & $\begin{array}{l}0.0176 \\
0.0495 \\
0.0879 \\
0.1319 \\
0.1546\end{array}$ & $\begin{array}{l}100 \\
100 \\
100 \\
100 \\
100\end{array}$ \\
\hline & 200 & $\begin{array}{l}2 \\
3 \\
4 \\
5 \\
6\end{array}$ & $\begin{array}{l}-0.0008 \\
-0.0033 \\
-0.0045 \\
-0.0046 \\
-0.0120\end{array}$ & $\begin{array}{l}0.0086 \\
0.0237 \\
0.0341 \\
0.0583 \\
0.0710\end{array}$ & $\begin{array}{l}100 \\
100 \\
100 \\
100 \\
100\end{array}$ & $\begin{array}{r}-0.0006 \\
0.0007 \\
0.0080 \\
0.0192 \\
0.0263\end{array}$ & $\begin{array}{l}0.0091 \\
0.0255 \\
0.0336 \\
0.0618 \\
0.0820\end{array}$ & $\begin{array}{l}100 \\
100 \\
100 \\
100 \\
100\end{array}$ \\
\hline & 500 & $\begin{array}{l}2 \\
3 \\
4 \\
5 \\
6\end{array}$ & $\begin{array}{r}0.0000 \\
-0.0003 \\
-0.0007 \\
-0.0031 \\
-0.0033\end{array}$ & $\begin{array}{l}0.0033 \\
0.0099 \\
0.0142 \\
0.0231 \\
0.0297\end{array}$ & $\begin{array}{l}100 \\
100 \\
100 \\
100 \\
100\end{array}$ & $\begin{array}{l}0.0000 \\
0.0000 \\
0.0009 \\
0.0013 \\
0.0026\end{array}$ & $\begin{array}{l}0.0033 \\
0.0095 \\
0.0241 \\
0.0238 \\
0.0297\end{array}$ & $\begin{array}{l}100 \\
100 \\
100 \\
100 \\
100\end{array}$ \\
\hline \multirow{4}{*}{$\begin{array}{l}\text { Loading } \\
=0.90\end{array}$} & 50 & $\begin{array}{l}2 \\
3 \\
4 \\
5 \\
6\end{array}$ & $\begin{array}{r}0.0021 \\
-0.0315 \\
-0.0520 \\
-0.1301 \\
-0.2503\end{array}$ & $\begin{array}{l}0.0319 \\
0.0807 \\
0.1621 \\
0.1940 \\
0.2350\end{array}$ & $\begin{array}{r}100 \\
100 \\
100 \\
99 \\
95\end{array}$ & $\begin{array}{l}0.0135 \\
0.0474 \\
0.1361 \\
0.2996 \\
0.4846\end{array}$ & $\begin{array}{l}0.0420 \\
0.1141 \\
0.2070 \\
0.2413 \\
0.3209\end{array}$ & $\begin{array}{r}99 \\
100 \\
100 \\
100 \\
100\end{array}$ \\
\hline & 100 & $\begin{array}{l}2 \\
3 \\
4 \\
5 \\
6\end{array}$ & $\begin{array}{l}-0.0020 \\
-0.0147 \\
-0.0132 \\
-0.0375 \\
-0.0405\end{array}$ & $\begin{array}{l}0.0163 \\
0.0377 \\
0.0801 \\
0.1194 \\
0.1249\end{array}$ & $\begin{array}{l}100 \\
100 \\
100 \\
100 \\
100\end{array}$ & $\begin{array}{r}-0.0001 \\
0.0051 \\
0.0336 \\
0.0590 \\
0.1350\end{array}$ & $\begin{array}{l}0.0184 \\
0.0501 \\
0.0881 \\
0.1326 \\
0.1540\end{array}$ & $\begin{array}{l}100 \\
100 \\
100 \\
100 \\
100\end{array}$ \\
\hline & 200 & $\begin{array}{l}2 \\
3 \\
4 \\
5 \\
6\end{array}$ & $\begin{array}{l}-0.0011 \\
-0.0032 \\
-0.0047 \\
-0.0009 \\
-0.0113\end{array}$ & $\begin{array}{l}0.0078 \\
0.0231 \\
0.0349 \\
0.0572 \\
0.0718\end{array}$ & $\begin{array}{l}100 \\
100 \\
100 \\
100 \\
100\end{array}$ & $\begin{array}{r}-0.0007 \\
0.0011 \\
0.0086 \\
0.0218 \\
0.0285\end{array}$ & $\begin{array}{l}0.0081 \\
0.0255 \\
0.0340 \\
0.0603 \\
0.0828\end{array}$ & $\begin{array}{l}100 \\
100 \\
100 \\
100 \\
100\end{array}$ \\
\hline & 500 & $\begin{array}{l}2 \\
3 \\
4 \\
5 \\
6\end{array}$ & $\begin{array}{r}0.0007 \\
0.0000 \\
-0.0008 \\
-0.0029 \\
-0.0035\end{array}$ & $\begin{array}{l}0.0033 \\
0.0091 \\
0.0151 \\
0.0214 \\
0.0304\end{array}$ & $\begin{array}{l}100 \\
100 \\
100 \\
100 \\
100\end{array}$ & $\begin{array}{l}0.0010 \\
0.0003 \\
0.0006 \\
0.0009 \\
0.0016\end{array}$ & $\begin{array}{l}0.0036 \\
0.0095 \\
0.0143 \\
0.0230 \\
0.0303\end{array}$ & $\begin{array}{l}100 \\
100 \\
100 \\
100 \\
100\end{array}$ \\
\hline
\end{tabular}


Table B-4 Means and standard deviationg for parsimoniougly adjusted

\begin{tabular}{|c|c|c|c|c|c|c|c|c|}
\hline & \multirow{2}{*}{$\begin{array}{l}\text { Sample } \\
\text { size }\end{array}$} & \multirow{2}{*}{$\begin{array}{l}\mathrm{p} / \mathrm{m} \\
\text { ratio }\end{array}$} & \multicolumn{3}{|c|}{ GLS } & \multicolumn{3}{|c|}{ ML } \\
\hline & & & Mean & SD & $\mathrm{n}$ & Mean & SD & $\mathbf{n}$ \\
\hline \multirow{4}{*}{$\begin{array}{l}\text { Loading } \\
=0.50\end{array}$} & 50 & $\begin{array}{l}2 \\
3 \\
4 \\
5 \\
6\end{array}$ & $\begin{array}{l}0.4653 \\
0.6820 \\
0.8343 \\
0.8965 \\
1.0412\end{array}$ & $\begin{array}{l}0.0151 \\
0.0510 \\
0.0755 \\
0.1272 \\
0.1334\end{array}$ & & $\begin{array}{l}0.4591 \\
0.5821 \\
0.7345 \\
0.7356 \\
0.6745\end{array}$ & $\begin{array}{l}0.0209 \\
0.1891 \\
0.0890 \\
0.1161 \\
0.1210\end{array}$ & $\begin{array}{l}97 \\
58 \\
95 \\
27 \\
99\end{array}$ \\
\hline & 100 & $\begin{array}{l}2 \\
3 \\
4 \\
5 \\
6\end{array}$ & $\begin{array}{l}0.4680 \\
0.7026 \\
0.7981 \\
0.8629 \\
0.8929\end{array}$ & $\begin{array}{l}0.0070 \\
0.0201 \\
0.0381 \\
0.0584 \\
0.0658\end{array}$ & & $\begin{array}{l}0.4673 \\
0.6942 \\
0.7739 \\
0.8155 \\
0.8121\end{array}$ & $\begin{array}{l}0.0077 \\
0.0246 \\
0.0426 \\
0.0637 \\
0.0719\end{array}$ & $\begin{array}{r}99 \\
99 \\
100 \\
100 \\
100\end{array}$ \\
\hline & 200 & $\begin{array}{l}2 \\
3 \\
4 \\
5 \\
6\end{array}$ & $\begin{array}{l}0.4667 \\
0.6970 \\
0.7906 \\
0.8416 \\
0.8767\end{array}$ & $\begin{array}{l}0.0055 \\
0.0119 \\
0.0170 \\
0.0293 \\
0.0357\end{array}$ & & $\begin{array}{l}0.4667 \\
0.6948 \\
0.7844 \\
0.8297 \\
0.9573\end{array}$ & $\begin{array}{l}0.0055 \\
0.0128 \\
0.0176 \\
0.0302 \\
0.0409\end{array}$ & $\begin{array}{l}100 \\
100 \\
100 \\
100 \\
100\end{array}$ \\
\hline & 500 & $\begin{array}{l}2 \\
3 \\
4 \\
5 \\
6\end{array}$ & $\begin{array}{l}0.4687 \\
0.6947 \\
0.7879 \\
0.8397 \\
0.8711\end{array}$ & $\begin{array}{l}0.0034 \\
0.0050 \\
0.0074 \\
0.0119 \\
0.0150\end{array}$ & & $\begin{array}{l}0.4687 \\
0.6945 \\
0.7871 \\
0.8373 \\
0.8681\end{array}$ & $\begin{array}{l}0.0034 \\
0.0052 \\
0.0071 \\
0.0122 \\
0.0151\end{array}$ & $\begin{array}{l}100 \\
100 \\
100 \\
100 \\
100\end{array}$ \\
\hline \multirow{4}{*}{$\begin{array}{l}\text { Lodding } \\
=0.70\end{array}$} & 50 & $\begin{array}{l}2 \\
3 \\
4 \\
5 \\
6\end{array}$ & $\begin{array}{l}0.4700 \\
0.7132 \\
0.8236 \\
0.9136 \\
1.0220\end{array}$ & $\begin{array}{l}0.0142 \\
0.0404 \\
0.0789 \\
0.1051 \\
0.1311\end{array}$ & & $\begin{array}{l}0.4644 \\
0.6755 \\
0.7309 \\
0.7114 \\
0.6707\end{array}$ & $\begin{array}{l}0.0184 \\
0.0520 \\
0.0903 \\
0.1036 \\
0.1216\end{array}$ & $\begin{array}{l}100 \\
100 \\
100 \\
100 \\
100\end{array}$ \\
\hline & 100 & $\begin{array}{l}2 \\
3 \\
4 \\
5 \\
6\end{array}$ & $\begin{array}{l}0.4676 \\
0.7015 \\
0.7961 \\
0.8595 \\
0.8904\end{array}$ & $\begin{array}{l}0.0082 \\
0.0196 \\
0.0391 \\
0.0604 \\
0.0653\end{array}$ & & $\begin{array}{l}0.4666 \\
0.6930 \\
0.7730 \\
0.8123 \\
0.8092\end{array}$ & $\begin{array}{l}0.0090 \\
0.0244 \\
0.0424 \\
0.0634 \\
0.0722\end{array}$ & $\begin{array}{l}100 \\
100 \\
100 \\
100 \\
100\end{array}$ \\
\hline & 200 & $\begin{array}{l}2 \\
3 \\
4 \\
5 \\
6\end{array}$ & $\begin{array}{l}0.4675 \\
0.6959 \\
0.7906 \\
0.8409 \\
0.8764\end{array}$ & $\begin{array}{l}0.0046 \\
0.0122 \\
0.0170 \\
0.0295 \\
0.0367\end{array}$ & & $\begin{array}{l}0.4670 \\
0.6943 \\
0.7836 \\
0.8292 \\
0.8564\end{array}$ & $\begin{array}{l}0.0050 \\
0.0122 \\
0.0169 \\
0.0299 \\
0.0411\end{array}$ & $\begin{array}{l}100 \\
100 \\
100 \\
100 \\
100\end{array}$ \\
\hline & 500 & $\begin{array}{l}2 \\
3 \\
4 \\
5 \\
6\end{array}$ & $\begin{array}{l}0.4691 \\
0.6946 \\
0.7879 \\
0.8393 \\
0.8711\end{array}$ & $\begin{array}{l}0.0029 \\
0.0050 \\
0.0077 \\
0.0118 \\
0.014 .\end{array}$ & & $\begin{array}{l}0.4689 \\
0.6944 \\
0.7874 \\
0.8378 \\
0.8686\end{array}$ & $\begin{array}{l}0.0031 \\
0.0050 \\
0.0076 \\
0.0119 \\
0.0147\end{array}$ & $\begin{array}{l}100 \\
100 \\
100 \\
100 \\
100\end{array}$ \\
\hline \multirow{4}{*}{$\begin{array}{l}\text { Loading } \\
=0.90\end{array}$} & 50 & $\begin{array}{l}2 \\
3 \\
4 \\
5 \\
6\end{array}$ & $\begin{array}{l}0.4659 \\
0.7120 \\
0.9183 \\
0.9115 \\
1.0127\end{array}$ & $\begin{array}{l}0.0160 \\
0.0399 \\
0.0822 \\
0.1061 \\
0.1343\end{array}$ & & $\begin{array}{l}0.4611 \\
0.6734 \\
0.7291 \\
0.7091 \\
0.6692\end{array}$ & $\begin{array}{l}0.0206 \\
0.0546 \\
0.0926 \\
0.1036 \\
0.1230\end{array}$ & $\begin{array}{r}99 \\
100 \\
100 \\
100 \\
100\end{array}$ \\
\hline & 100 & $\begin{array}{l}2 \\
3 \\
4 \\
5 \\
6\end{array}$ & $\begin{array}{l}0.4677 \\
0.7019 \\
0.7957 \\
0.8597 \\
0.9920\end{array}$ & $\begin{array}{l}0.0084 \\
0.0191 \\
0.0406 \\
0.0596 \\
0.0637\end{array}$ & & $\begin{array}{l}0.4669 \\
0.6926 \\
0.7724 \\
0.8117 \\
0.8074\end{array}$ & $\begin{array}{l}0.0093 \\
0.0254 \\
0.0429 \\
0.0635 \\
0.0711\end{array}$ & $\begin{array}{l}100 \\
100 \\
100 \\
100 \\
100\end{array}$ \\
\hline & 200 & $\begin{array}{l}2 \\
3 \\
4 \\
5 \\
6\end{array}$ & $\begin{array}{l}0.4674 \\
0.6960 \\
0.7910 \\
0.8387 \\
0.8762\end{array}$ & $\begin{array}{l}0.0046 \\
0.0119 \\
0.0173 \\
0.0286 \\
0.0360\end{array}$ & & $\begin{array}{l}0.4675 \\
0.6941 \\
0.7843 \\
0.8277 \\
0.8559\end{array}$ & $\begin{array}{l}0.0046 \\
0.0126 \\
0.0171 \\
0.0295 \\
0.0406\end{array}$ & $\begin{array}{l}100 \\
100 \\
100 \\
100 \\
100\end{array}$ \\
\hline & 500 & $\begin{array}{l}2 \\
3 \\
4 \\
5 \\
6\end{array}$ & $\begin{array}{l}0.4684 \\
0.6945 \\
0.7890 \\
0.8394 \\
0.8711\end{array}$ & $\begin{array}{l}0.0037 \\
0.0052 \\
0.0078 \\
0.0114 \\
0.0157\end{array}$ & & $\begin{array}{l}0.4684 \\
0.6939 \\
0.7977 \\
0.9380 \\
0.8686\end{array}$ & $\begin{array}{l}0.0037 \\
0.0055 \\
0.0080 \\
0.0115 \\
0.0154\end{array}$ & $\begin{array}{l}100 \\
100 \\
100 \\
100 \\
100\end{array}$ \\
\hline
\end{tabular}


Table B-5

Means and standard deviations for parsimoniously adjusted Relative Noncentrality Index

\begin{tabular}{|c|c|c|c|c|c|c|c|c|}
\hline \multirow{2}{*}{\multicolumn{2}{|c|}{$\begin{array}{l}\text { Sample } \\
\text { size }\end{array}$}} & \multirow[b]{2}{*}{$\underset{\text { ratio }}{\mathrm{p} / \mathrm{m}}$} & \multicolumn{3}{|c|}{ GLS } & \multicolumn{3}{|c|}{$\mathrm{MIL}$} \\
\hline & & & Mean & SD & $\mathrm{I}$ & Mean & SD & $\mathrm{n}$ \\
\hline \multirow{4}{*}{$\begin{array}{l}\text { Loading } \\
=0.50\end{array}$} & 50 & $\begin{array}{l}2 \\
3 \\
4 \\
5 \\
6\end{array}$ & $\begin{array}{l}0.4667 \\
0.6919 \\
0.7939 \\
0.8419 \\
0.8759\end{array}$ & $\begin{array}{l}0.0060 \\
0.0113 \\
0.0087 \\
0.0100 \\
0.0065\end{array}$ & $\begin{array}{l}93 \\
69 \\
90 \\
37 \\
78\end{array}$ & $\begin{array}{l}0.4209 \\
0.5243 \\
0.7281 \\
0.7356 \\
0.7209\end{array}$ & $\begin{array}{l}0.2338 \\
2.3935 \\
0.1611 \\
0.1271 \\
0.0988\end{array}$ & $\begin{array}{l}97 \\
58 \\
95 \\
27 \\
99\end{array}$ \\
\hline & 100 & $\begin{array}{l}2 \\
3 \\
4 \\
5 \\
6\end{array}$ & $\begin{array}{l}0.4680 \\
0.6964 \\
0.7897 \\
0.8409 \\
0.8715\end{array}$ & $\begin{array}{l}0.0040 \\
0.0063 \\
0.0071 \\
0.0067 \\
0.0058\end{array}$ & $\begin{array}{r}97 \\
100 \\
99 \\
98 \\
97\end{array}$ & $\begin{array}{l}0.4693 \\
0.7004 \\
0.7698 \\
0.8144 \\
0.8233\end{array}$ & $\begin{array}{l}0.0477 \\
0.0670 \\
0.0630 \\
0.0721 \\
0.0616\end{array}$ & $\begin{array}{r}99 \\
99 \\
100 \\
100 \\
100\end{array}$ \\
\hline & 200 & $\begin{array}{l}2 \\
3 \\
4 \\
5 \\
6\end{array}$ & $\begin{array}{l}0.4684 \\
0.6956 \\
0.7885 \\
0.8384 \\
0.8706\end{array}$ & $\begin{array}{l}0.0037 \\
0.0052 \\
0.0039 \\
0.0049 \\
0.0040\end{array}$ & $\begin{array}{r}100 \\
99 \\
100 \\
100 \\
100\end{array}$ & $\begin{array}{l}0.4668 \\
0.6966 \\
0.7829 \\
0.8292 \\
0.8594\end{array}$ & $\begin{array}{l}0.0239 \\
0.0324 \\
0.0252 \\
0.0333 \\
0.0320\end{array}$ & $\begin{array}{l}100 \\
100 \\
100 \\
100 \\
100\end{array}$ \\
\hline & 500 & $\begin{array}{l}2 \\
3 \\
4 \\
5 \\
6\end{array}$ & $\begin{array}{l}0.4696 \\
0.6935 \\
0.7898 \\
0.8397 \\
0.8700\end{array}$ & $\begin{array}{l}0.0020 \\
0.0048 \\
0.0014 \\
0.0017 \\
0.0000\end{array}$ & $\begin{array}{l}100 \\
100 \\
100 \\
100 \\
100\end{array}$ & $\begin{array}{l}0.4676 \\
0.6951 \\
0.7871 \\
0.8372 \\
0.8683\end{array}$ & $\begin{array}{l}0.0094 \\
0.0111 \\
0.0105 \\
0.0136 \\
0.0122\end{array}$ & $\begin{array}{l}100 \\
100 \\
100 \\
100 \\
100\end{array}$ \\
\hline \multirow{4}{*}{$\begin{array}{l}\text { Loading } \\
=0.70\end{array}$} & 50 & $\begin{array}{l}2 \\
3 \\
4 \\
5 \\
6\end{array}$ & $\begin{array}{l}0.4673 \\
0.6967 \\
0.7898 \\
0.8407 \\
0.8715\end{array}$ & $\begin{array}{l}0.0045 \\
0.0049 \\
0.0040 \\
0.0036 \\
0.0036\end{array}$ & $\begin{array}{r}100 \\
100 \\
99 \\
98 \\
94\end{array}$ & $\begin{array}{l}0.4648 \\
0.6800 \\
0.7581 \\
0.7886 \\
0.8077\end{array}$ & $\begin{array}{l}0.0330 \\
0.0423 \\
0.0508 \\
0.0411 \\
0.0425\end{array}$ & $\begin{array}{l}100 \\
100 \\
100 \\
100 \\
100\end{array}$ \\
\hline & 100 & $\begin{array}{l}2 \\
3 \\
4 \\
5 \\
6\end{array}$ & $\begin{array}{l}0.4684 \\
0.6956 \\
0.7896 \\
0.8394 \\
0.8701\end{array}$ & $\begin{array}{l}0.0037 \\
0.0050 \\
0.0028 \\
0.0031 \\
0.0017\end{array}$ & $\begin{array}{l}100 \\
100 \\
100 \\
100 \\
100\end{array}$ & $\begin{array}{l}0.4670 \\
0.6941 \\
0.7798 \\
0.8280 \\
0.8514\end{array}$ & $\begin{array}{l}0.0149 \\
0.0204 \\
0.0220 \\
0.0244 \\
0.0220\end{array}$ & $\begin{array}{l}100 \\
100 \\
100 \\
100 \\
100\end{array}$ \\
\hline & 200 & $\begin{array}{l}2 \\
3 \\
4 \\
5 \\
6\end{array}$ & $\begin{array}{l}0.4695 \\
0.6944 \\
0.7899 \\
0.8394 \\
0.8700\end{array}$ & $\begin{array}{l}0.0022 \\
0.0050 \\
0.0010 \\
0.0024 \\
0.0000\end{array}$ & $\begin{array}{l}100 \\
100 \\
100 \\
100 \\
100\end{array}$ & $\begin{array}{l}0.4669 \\
0.6942 \\
0.7857 \\
0.8339 \\
0.8653\end{array}$ & $\begin{array}{l}0.0072 \\
0.0112 \\
0.0091 \\
0.0112 \\
0.0113\end{array}$ & $\begin{array}{l}100 \\
100 \\
100 \\
100 \\
100\end{array}$ \\
\hline & 500 & $\begin{array}{l}2 \\
3 \\
4 \\
5 \\
6\end{array}$ & $\begin{array}{l}0.4700 \\
0.5922 \\
0.7900 \\
0.8400 \\
0.8700\end{array}$ & $\begin{array}{l}0.0000 \\
0.0042 \\
0.0000 \\
0.0000 \\
0.0000\end{array}$ & $\begin{array}{l}100 \\
100 \\
100 \\
100 \\
100\end{array}$ & $\begin{array}{l}0.4684 \\
0.6940 \\
0.7878 \\
0.8379 \\
0.9692\end{array}$ & $\begin{array}{l}0.0037 \\
0.0049 \\
0.0042 \\
0.0050 \\
0.0049\end{array}$ & $\begin{array}{l}100 \\
100 \\
100 \\
100 \\
100\end{array}$ \\
\hline \multirow{4}{*}{$\begin{array}{l}\text { Loading } \\
=0.90\end{array}$} & 50 & $\begin{array}{l}2 \\
3 \\
4 \\
5 \\
6\end{array}$ & $\begin{array}{l}0.4700 \\
0.6928 \\
0.7900 \\
0.8400 \\
0.8700\end{array}$ & $\begin{array}{l}0.0000 \\
0.0045 \\
0.0000 \\
0.0000 \\
0.0000\end{array}$ & $\begin{array}{r}100 \\
100 \\
100 \\
98 \\
95\end{array}$ & $\begin{array}{l}0.4634 \\
0.6882 \\
0.7772 \\
0.9202 \\
0.846 E\end{array}$ & $\begin{array}{l}0.0114 \\
0.0145 \\
0.0175 \\
0.0151 \\
0.0162\end{array}$ & $\begin{array}{l}99 \\
100 \\
100 \\
100 \\
100\end{array}$ \\
\hline & 100 & $\begin{array}{l}2 \\
3 \\
4 \\
5 \\
6\end{array}$ & $\begin{array}{l}0.4700 \\
0.6912 \\
0.7900 \\
0.8400 \\
0.8700\end{array}$ & $\begin{array}{l}0.0000 \\
0.0033 \\
0.0000 \\
0.0000 \\
0.0000\end{array}$ & $\begin{array}{l}100 \\
100 \\
100 \\
100 \\
100\end{array}$ & $\begin{array}{l}0.4667 \\
0.6939 \\
0.7847 \\
0.8341 \\
0.8633\end{array}$ & $\begin{array}{l}0.0057 \\
0.0072 \\
0.0074 \\
0.0085 \\
0.0084\end{array}$ & $\begin{array}{l}100 \\
100 \\
100 \\
100 \\
100\end{array}$ \\
\hline & 200 & $\begin{array}{l}2 \\
3 \\
4 \\
5 \\
6\end{array}$ & $\begin{array}{l}0.4700 \\
0.6900 \\
0.7900 \\
0.8400 \\
0.8700\end{array}$ & $\begin{array}{l}0.0000 \\
0.0000 \\
0.0000 \\
0.0000 \\
0.0000\end{array}$ & $\begin{array}{l}100 \\
100 \\
100 \\
100 \\
100\end{array}$ & $\begin{array}{l}0.4683 \\
0.6949 \\
0.7879 \\
0.8369 \\
0.8686\end{array}$ & $\begin{array}{l}0.0038 \\
0.0050 \\
0.0041 \\
0.0046 \\
0.0049\end{array}$ & $\begin{array}{l}100 \\
100 \\
100 \\
100 \\
100\end{array}$ \\
\hline & 500 & $\begin{array}{l}2 \\
3 \\
4 \\
5 \\
6\end{array}$ & $\begin{array}{l}0.4700 \\
0.6900 \\
0.7900 \\
0.8400 \\
0.8700\end{array}$ & $\begin{array}{l}0.0000 \\
0.0000 \\
0.0000 \\
0.0000 \\
0.0000\end{array}$ & $\begin{array}{l}100 \\
100 \\
100 \\
100 \\
100\end{array}$ & $\begin{array}{l}0.4694 \\
0.6929 \\
0.7900 \\
0.839 \mathrm{~B} \\
0.9700\end{array}$ & $\begin{array}{l}0.0024 \\
0.0046 \\
0.0000 \\
0.0014 \\
0.0000\end{array}$ & $\begin{array}{l}100 \\
100 \\
100 \\
100 \\
100\end{array}$ \\
\hline
\end{tabular}


Table B-6

Meang and standard deviations for parsimoniously adjusted Comparative Pit Index

\begin{tabular}{|c|c|c|c|c|c|c|c|c|}
\hline \multirow{2}{*}{\multicolumn{2}{|c|}{$\begin{array}{c}\text { Sample } \\
\text { size }\end{array}$}} & \multirow{2}{*}{$\begin{array}{l}\mathrm{p} / \mathrm{m} \\
\text { Iatio }\end{array}$} & \multicolumn{3}{|c|}{ GLS } & \multicolumn{3}{|c|}{ MIL } \\
\hline & & & Mean & $S D$ & $\mathrm{n}$ & Mean & $\mathrm{SD}$ & $\mathrm{n}$ \\
\hline \multirow{4}{*}{$\begin{array}{l}\text { Loading } \\
=0.50\end{array}$} & 50 & $\begin{array}{l}2 \\
3 \\
4 \\
5 \\
6\end{array}$ & $\begin{array}{l}0.4663 \\
0.6862 \\
0.7886 \\
0.8378 \\
0.8700\end{array}$ & $\begin{array}{l}0.0055 \\
0.0062 \\
0.0035 \\
0.0042 \\
0.0000\end{array}$ & $\begin{array}{l}93 \\
69 \\
90 \\
37 \\
78\end{array}$ & $\begin{array}{l}0.4201 \\
0.4705 \\
0.6997 \\
0.7178 \\
0.7186\end{array}$ & $\begin{array}{l}0.0696 \\
0.2818 \\
0.1019 \\
0.0985 \\
0.0943\end{array}$ & $\begin{array}{l}96 \\
58 \\
95 \\
27 \\
99\end{array}$ \\
\hline & 100 & $\begin{array}{l}2 \\
3 \\
4 \\
5 \\
6\end{array}$ & $\begin{array}{l}0.4680 \\
0.6898 \\
0.7876 \\
0.8384 \\
0.8691\end{array}$ & $\begin{array}{l}0.0040 \\
0.0014 \\
0.0045 \\
0.0040 \\
0.0029\end{array}$ & $\begin{array}{r}97 \\
100 \\
99 \\
98 \\
97\end{array}$ & $\begin{array}{l}0.4528 \\
0.6697 \\
0.7529 \\
0.7976 \\
0.8154\end{array}$ & $\begin{array}{l}0.0299 \\
0.0348 \\
0.0431 \\
0.0509 \\
0.0498\end{array}$ & $\begin{array}{r}99 \\
99 \\
100 \\
100 \\
100\end{array}$ \\
\hline & 200 & $\begin{array}{l}2 \\
3 \\
4 \\
5 \\
6\end{array}$ & $\begin{array}{l}0.4684 \\
0.6899 \\
0.7884 \\
0.8379 \\
0.8695\end{array}$ & $\begin{array}{l}0.0037 \\
0.0010 \\
0.0037 \\
0.0041 \\
0.0022\end{array}$ & $\begin{array}{r}100 \\
99 \\
100 \\
100 \\
100\end{array}$ & $\begin{array}{l}0.4599 \\
0.6803 \\
0.7761 \\
0.8206 \\
0.8513\end{array}$ & $\begin{array}{l}0.0175 \\
0.0175 \\
0.0175 \\
0.0234 \\
0.0207\end{array}$ & $\begin{array}{l}100 \\
100 \\
100 \\
100 \\
100\end{array}$ \\
\hline & 500 & $\begin{array}{l}2 \\
3 \\
4 \\
5 \\
6\end{array}$ & $\begin{array}{l}0.4696 \\
0.6900 \\
0.7898 \\
0.8397 \\
0.8700\end{array}$ & $\begin{array}{l}0.0020 \\
0.0000 \\
0.0014 \\
0.0017 \\
0.0000\end{array}$ & $\begin{array}{l}100 \\
100 \\
100 \\
100 \\
100\end{array}$ & $\begin{array}{l}0.4656 \\
0.6880 \\
0.7845 \\
0.8332 \\
0.8644\end{array}$ & $\begin{array}{l}0.0074 \\
0.0047 \\
0.0074 \\
0.0091 \\
0.0081\end{array}$ & $\begin{array}{l}100 \\
100 \\
100 \\
100 \\
100\end{array}$ \\
\hline \multirow{4}{*}{$\begin{array}{l}\text { Loading } \\
=0.70\end{array}$} & 50 & $\begin{array}{l}2 \\
3 \\
4 \\
5 \\
6\end{array}$ & $\begin{array}{l}0.4673 \\
0.6900 \\
0.7891 \\
0.8397 \\
0.8700\end{array}$ & $\begin{array}{l}0.0045 \\
0.0000 \\
0.0029 \\
0.0017 \\
0.0000\end{array}$ & $\begin{array}{r}100 \\
100 \\
99 \\
98 \\
94\end{array}$ & $\begin{array}{l}0.4542 \\
0.6686 \\
0.7522 \\
0.7859 \\
0.8070\end{array}$ & $\begin{array}{l}0.0220 \\
0.0306 \\
0.0433 \\
0.0364 \\
0.0412\end{array}$ & $\begin{array}{l}100 \\
100 \\
100 \\
100 \\
100\end{array}$ \\
\hline & 100 & $\begin{array}{l}2 \\
3 \\
4 \\
5 \\
6\end{array}$ & $\begin{array}{l}0.4684 \\
0.6900 \\
0.7894 \\
0.8392 \\
0.8699\end{array}$ & $\begin{array}{l}0.0037 \\
0.0000 \\
0.0024 \\
0.0027 \\
0.0010\end{array}$ & $\begin{array}{l}100 \\
100 \\
100 \\
100 \\
100\end{array}$ & $\begin{array}{l}0.4631 \\
0.6839 \\
0.7755 \\
0.8235 \\
0.8492\end{array}$ & $\begin{array}{l}0.0113 \\
0.0116 \\
0.0170 \\
0.0189 \\
0.0187\end{array}$ & $\begin{array}{l}100 \\
100 \\
100 \\
100 \\
100\end{array}$ \\
\hline & 200 & $\begin{array}{l}2 \\
3 \\
4 \\
5 \\
6\end{array}$ & $\begin{array}{l}0.4695 \\
0.6900 \\
0.7899 \\
0.8394 \\
0.8700\end{array}$ & $\begin{array}{l}0.0022 \\
0.0000 \\
0.0010 \\
0.0024 \\
0.0000\end{array}$ & $\begin{array}{l}100 \\
100 \\
100 \\
100 \\
100\end{array}$ & $\begin{array}{l}0.4663 \\
0.6874 \\
0.7843 \\
0.8319 \\
0.8629\end{array}$ & $\begin{array}{l}0.0065 \\
0.0058 \\
0.0074 \\
0.0088 \\
0.0078\end{array}$ & $\begin{array}{l}100 \\
100 \\
100 \\
100 \\
100\end{array}$ \\
\hline & 500 & $\begin{array}{l}2 \\
3 \\
4 \\
5 \\
6\end{array}$ & $\begin{array}{l}0.4700 \\
0.6900 \\
0.7900 \\
0.8400 \\
0.8700\end{array}$ & $\begin{array}{l}0.0000 \\
0.0000 \\
0.0000 \\
0.0000 \\
0.0000\end{array}$ & $\begin{array}{l}100 \\
100 \\
100 \\
100 \\
100\end{array}$ & $\begin{array}{l}0.4684 \\
0.6900 \\
0.7878 \\
0.8375 \\
0.8684\end{array}$ & $\begin{array}{l}0.0037 \\
0.0000 \\
0.0042 \\
0.0044 \\
0.0037\end{array}$ & $\begin{array}{l}100 \\
100 \\
100 \\
100 \\
100\end{array}$ \\
\hline \multirow{4}{*}{$\begin{array}{l}\text { Loading } \\
=0.90\end{array}$} & 50 & $\begin{array}{l}2 \\
3 \\
4 \\
5 \\
6\end{array}$ & $\begin{array}{l}0.4700 \\
0.6900 \\
0.7900 \\
0.8400 \\
0.8700\end{array}$ & $\begin{array}{l}0.0000 \\
0.0000 \\
0.0000 \\
0.0000 \\
0.0000\end{array}$ & $\begin{array}{r}100 \\
100 \\
100 \\
98 \\
95\end{array}$ & $\begin{array}{l}0.4621 \\
0.6837 \\
0.7755 \\
0.8194 \\
0.8463\end{array}$ & $\begin{array}{l}0.0098 \\
0.0100 \\
0.0153 \\
0.0136 \\
0.0155\end{array}$ & $\begin{array}{l}99 \\
100 \\
100 \\
100 \\
100\end{array}$ \\
\hline & 100 & $\begin{array}{l}2 \\
3 \\
4 \\
5 \\
6\end{array}$ & $\begin{array}{l}0.4700 \\
0.6900 \\
0.7900 \\
0.8400 \\
0.9700\end{array}$ & $\begin{array}{l}0.0000 \\
0.0000 \\
0.0000 \\
0.0000 \\
0.0000\end{array}$ & $\begin{array}{l}100 \\
100 \\
100 \\
100 \\
100\end{array}$ & $\begin{array}{l}0.4666 \\
0.6889 \\
0.7842 \\
0.8333 \\
0.8626\end{array}$ & $\begin{array}{l}0.0055 \\
0.0031 \\
0.0067 \\
0.0074 \\
0.0073\end{array}$ & $\begin{array}{l}100 \\
100 \\
100 \\
100 \\
100\end{array}$ \\
\hline & 200 & $\begin{array}{l}2 \\
3 \\
4 \\
5 \\
6\end{array}$ & $\begin{array}{l}0.4700 \\
0.6900 \\
0.7900 \\
0.8400 \\
0.8700\end{array}$ & $\begin{array}{l}0.0000 \\
0.0000 \\
0.0000 \\
0.0000 \\
0.0000\end{array}$ & $\begin{array}{l}100 \\
100 \\
100 \\
100 \\
100\end{array}$ & $\begin{array}{l}0.4683 \\
0.6900 \\
0.7879 \\
0.8369 \\
0.8680\end{array}$ & $\begin{array}{l}0.0038 \\
0.0000 \\
0.0041 \\
0.0046 \\
0.0040\end{array}$ & $\begin{array}{l}100 \\
100 \\
100 \\
100 \\
100\end{array}$ \\
\hline & 500 & $\begin{array}{l}2 \\
3 \\
4 \\
5 \\
6\end{array}$ & $\begin{array}{l}0.4700 \\
0.6900 \\
0.7900 \\
0.8400 \\
0.8700\end{array}$ & $\begin{array}{l}0.0000 \\
0.0000 \\
0.0000 \\
0.0000 \\
0.0000\end{array}$ & $\begin{array}{l}100 \\
100 \\
100 \\
100 \\
100\end{array}$ & $\begin{array}{l}0.4694 \\
0.6900 \\
0.7900 \\
0.8398 \\
0.8700\end{array}$ & $\begin{array}{l}0.0024 \\
0.0000 \\
0.0000 \\
0.0014 \\
0.0000\end{array}$ & $\begin{array}{l}100 \\
100 \\
100 \\
100 \\
100\end{array}$ \\
\hline
\end{tabular}


APPENDIX C 


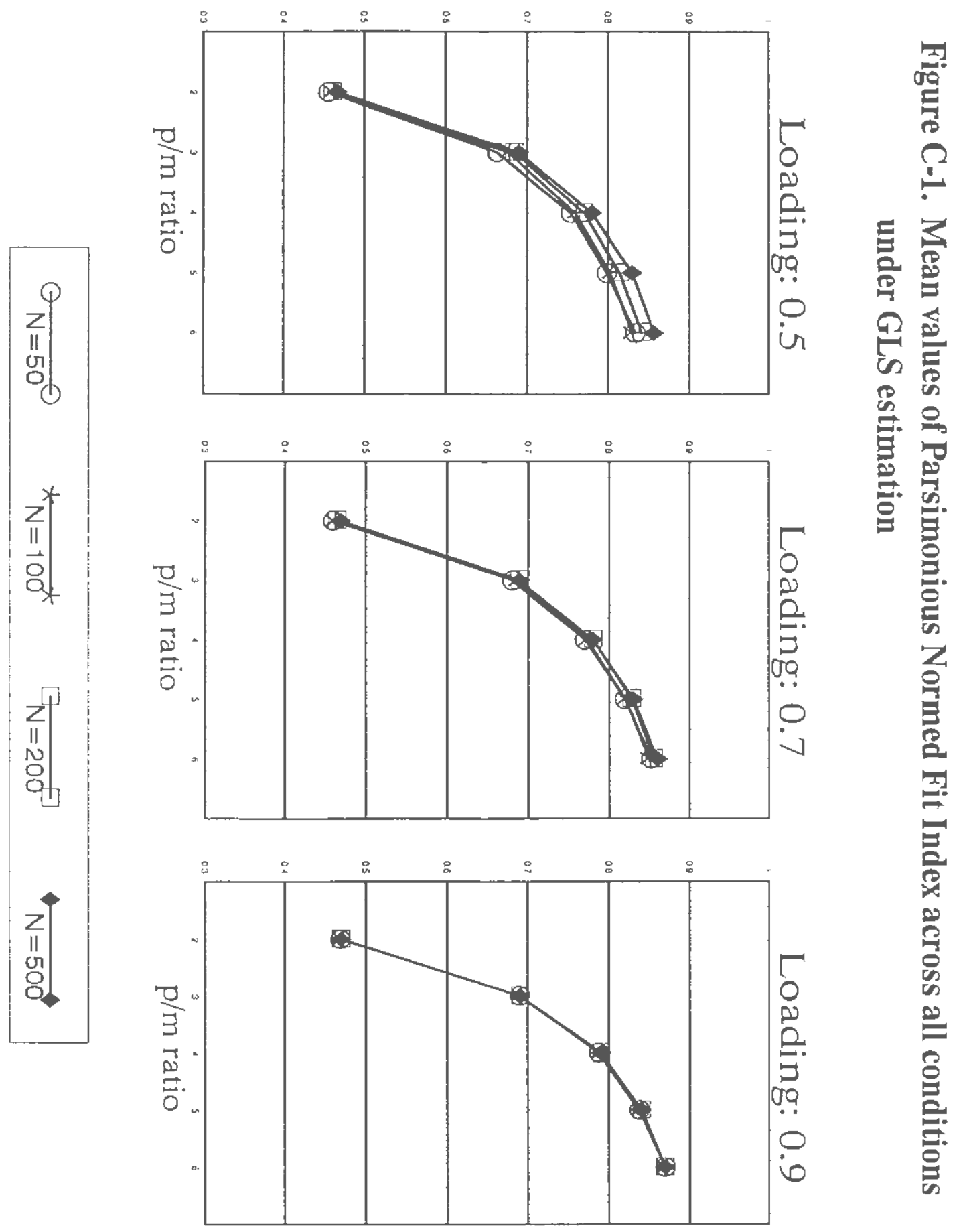



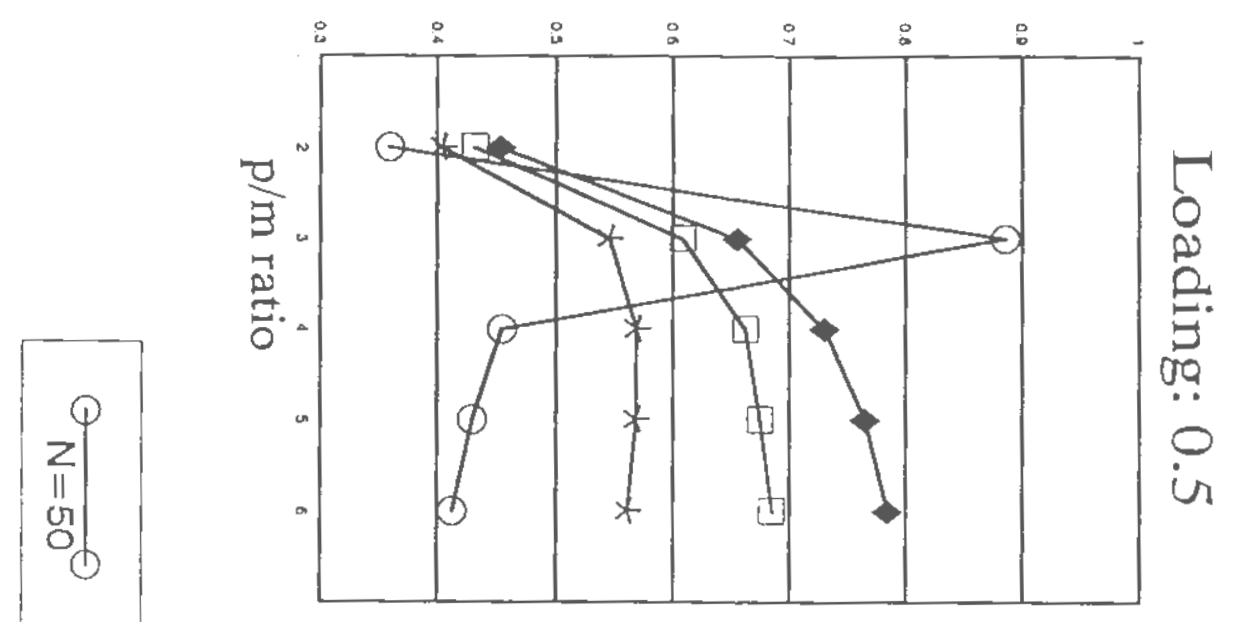

$\left|\begin{array}{c}z \\ \frac{11}{9}\end{array}\right|$
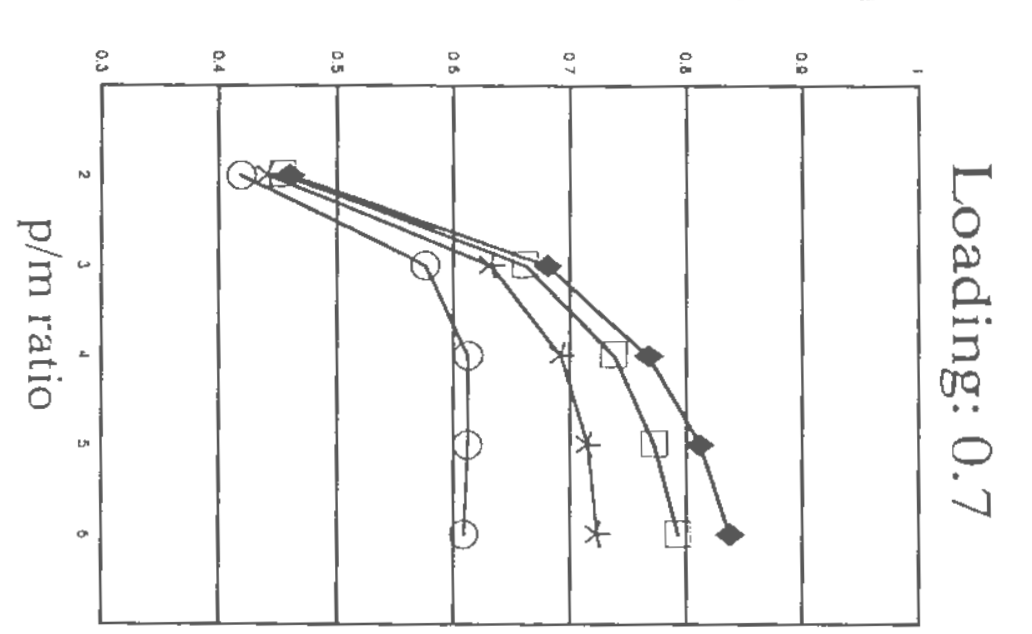

i⿱
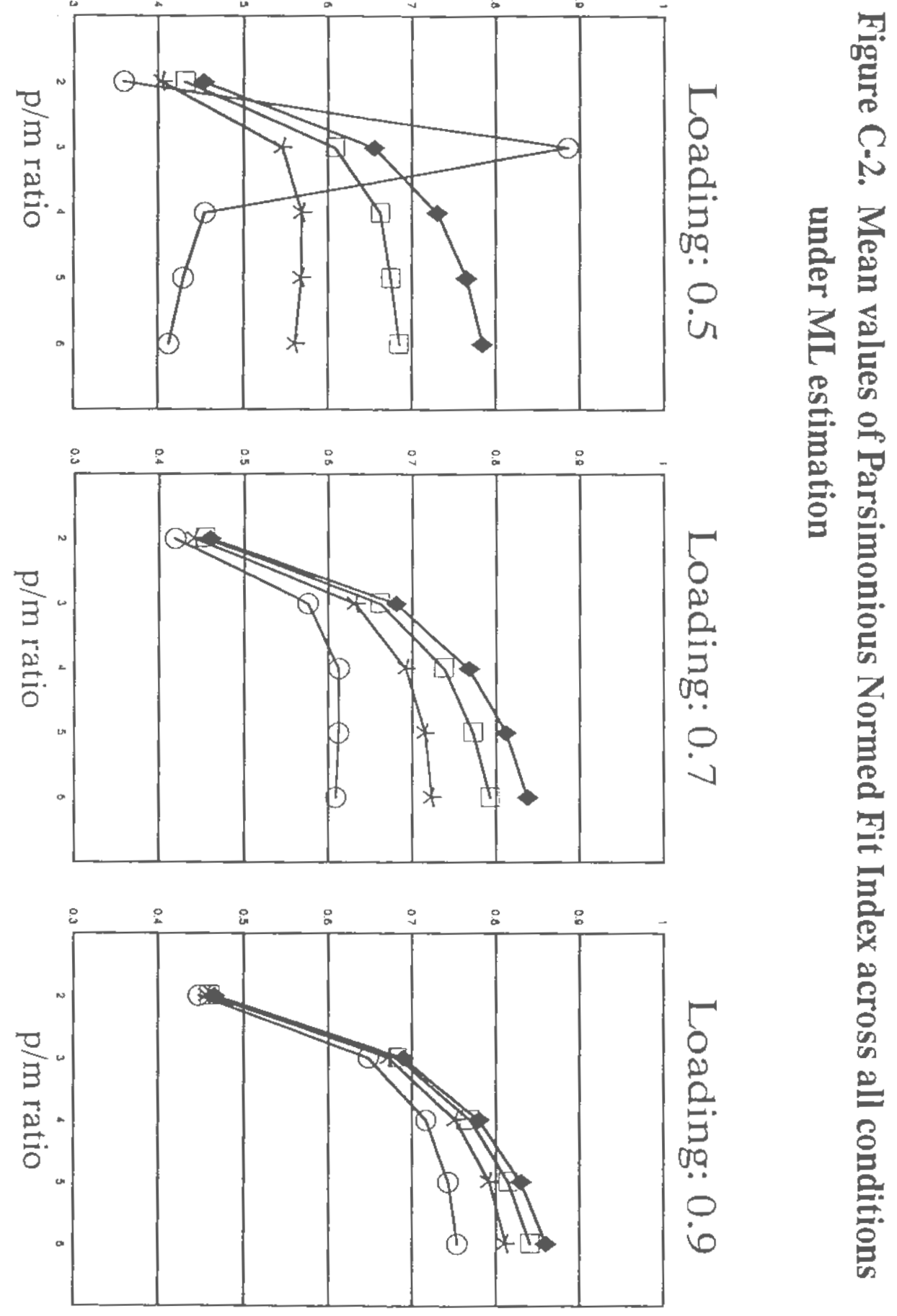


\section{BIBLIOGRAPHY}

Anderson, T.W. \& Rubin, H. (1956). Statistical inference in factor analysis. In J.Neyman (Ed), Proceedings of the Third Berkeley Symposium on Mathematical Statistics and Probability (pp. 111-150). Berkeley: University of California Press.

Anderson, J. C., \& Gerbing, D. W. (1984). The effect of sampling error on convergence, improper solutions, and goodness-of-fit indices for Maximum Likelihood confirmatory factor analysis. Psychometrika, 49, 155-172.

Bearden, W. O., Sharma, S., \& Teel, J. R. (1982). Sample size effects on chi-square and other statistics used in evaluating causal models. Journal of Marketing Research, 19, 425-530.

Bentler, P. M. (1989). EQS Structural Equations Program Manual. BMDP Statistical Software, Inc: Los Angeles.

Bentler, P. M. \& Wu, E. (1990). EQS Structural Equarions Program Manual (PC). BMDP Statistical Software, Inc: Los Angeles.

Bentler, P. M. (1990). Comparative fit indexes in structural models. Psycholozical Bulletin, 107, 256-259.

Bentler, P. M., \& Bonett, D. G. (1980). Significance tests and goodness of fit in the analysis of covariance structures. Psychological Bulletin, 88, 588-606.

Bollen, K. A., \& Long, J. S. (1993). Introduction. In Bollen \& Long (Eds): Testing Structural Equation Models, (pp. 1-9) Sage Publications, lnc.

Boomsma, A. (1982). The robustness of LISREL against small sample sizes in factor analysis models. In K.G. Joreskog and H. Wold (Eds.), Systems under indirect observation: Causality, structure, prediction (Part I). Amsterdam; North-Holland.

Boomsma, A. (1985). Nonconvergence, improper solutions, and starting values in LISREL maximum likelihood estimation. Psychometrika, 50, 229-242.

Brown, R. L. (1990). The robustness of 2SLS estimation of a Non-normally distributed confirmatory factor analysis model. Mulivariate Behavioral Research, 25, 455 466. 
Browne, M. W. (1974). Generalized least-squares estimators in the analysis of covariance structures. South African Statistical Journal, 8, 1-24.

Fava, J. L. \& Velicer, W. F. (1992a). An empirical comparison of factor, image, component, and scale scores. Multivariate Behavioral Research, 27, 301-322.

Fava, J. L. \& Velicer, W. F. (1992b). The effects of overextraction on factor and component analysis. Mulivariate Behavioral Research, 27, 387-415.

Fava, L. L. \& Velicer, W. F. (1993). The effects of underextraction in factor and component analysis. Manuscript under review.

Gerbing D. W. \& Anderson, J. C. (1987). Improper solutions in the analysis of covariance structures: Their interpretability and a comparison of alternate respecifications. Psychometrika, 52, 99-111

Gerbing, D. W. \& Anderson, J.C. (1993). Monte carlo evaluations of goodness of fit indices for structural equation models. In Bollen \& Long (Eds): Tesring Structural Equation Models, (pp. 40-65) Sage Publications, Inc.

Guadagnoli, E., \& Velicer, W. F. (1988). Relation of sample size to the stability of component patterns. Psychological Bulletin, 103, 265-275.

Harlow, L. L. (1985). Behavioral of some elliptical theory estimators with nonnormal data in a covariance structural framework: A Monte Carlo srudy. Unpublished Dissertation, University of California, Los Angeles.

Hoetler, J. (1983). The analysis of covariance structures: Goodness-of-fit indices. Sociological Merhods \& Research, 11, 325-344.

Huba, G. J., \& Harlow, L. L. (1983). Comparison of maximum likelihood, generalized least squares, ordinary least squares, and asymptotically distribution free parameter estimates in drug abuse latent variable causal models. Journal of Drug Educarion, 13, $387-403$

James, L. R., Mulaik, S. A., \& Brett, J. M. (1982). Causal analysis: Models, assumptions, and data. Beverly Hilis, CA: Sage.

Joreskog, K. G. \& Sorbom, D. (198I). LISREL V: Analysis of linear structural 
relationships by the method of maximum likelihood. Chicago: National Educational Resources.

Long, J. S. (1983) Covariance Structure Models - An Introduction to LISREL. Sage Publications, Inc.

La Du, T. J., \& Tanaka, J. S. (1989). The influence of sample size, estimation method, and model specification on goodness-of-fit assessments in structural equation models. Journal of Applied Psychology, 74, 625-636.

Marsh, H. W., Balla, J. R. and McDonald, R. P. (1988). Goodness-of-fit indexes in confirmatory factor analysis: The effect of sample size. Psychological Bulletin, $103,391-410$.

McDonald, R. P. (1989). An index of goodness-of-fit based on noncentrality. Journal of Classification, 6, 97-103.

McDonald, R. P., \& Marsh, H. W. (1990). Choosing a multivariate model:

Noncentrality and goodness of fit. Psychological Bullein., 107, 247-255.

Mulaik, S. A., James, L. R., Alstine, J. V., Bennett, N., Lind, S., and Stilwell, C. D. (1989). Evaluation of Goodness-of-fit indices for structural equation models. Psychological Bulletin. 105, 430-445.

Muthen, B. \& Kaplan, D. (1985). A comparison of some methodologies for the factor analysis of nonnormal Likert variables. British Journal of Mathematical and Statistical Psychology, 38, 171-189.

Steiger, J. H. (1990). Structural model evaluation and modification: An internal estimation approach. Multivariate Behavioral Research, 25, 173-180.

Tanaka, J. S. (1993). Multifaceted Conceptions of Fit in Structural Equation Models. In Bollen \& Long (Eds): Testing Structural Equation Models, (pp. 10-39), Sage Publications, Inc.

Tucker, l. R., \& Lewis, C. (1973). The reliability coefficient for maximum likelihood factor analysis. Psychometrika, 38, 1-10.

Velicer, W. F. (1974). A comparison of the stability of factor analysis, principal 
component analysis, and rescaled image analysis. Educational and Psychological Measuremeni, 34, 563-572.

Velicer, W. F., \& Fava, J. L. (1987). An evaluation of the effects of variable sampling on component, image, and factor analysis. Multivariate Behavioral Research, 22, 193-209.

Velicer, W. F., \& Fava, J. L. (1993). The effects of variable and subject sampling on factor pattern recovery. Manuscript submitted for publication.

Velicer, W. F., \& Jackson, D. M. (1990). Component analysis versus common factor analysis: Some issues in selecting an appropriate procedure. Mulrivariare Behavioral Research, 25, 1-28.

Velicer, W. F., Peacock, A. C., \& Jackson, D. N. (1982). A comparison of component and factor patterns: A Monte Carlo approach. Multivariate Behavioral Research, 17, 371-388.

Zwick, W.R., \& Velicer, W.F. (1982). Factors influencing four rules for determining the number of components to retain. Mulrivariate Behavioral Research, 17, 253269.

Zwick, W.R., \& Velicer, W.F. (1986). A comparison of five rules for determining the number of components to retain. Psychological Bulletin, 99, 432-442. 